\title{
A bibliography of works on reflexivity
}

\section{Citation}

Peter Suber, A bibliography of works on reflexivity, in Self-Reference: Reflections on Reflexivity 259-362 (Peter Suber and Steven J. Bartlett 1987).

\section{Permanent link}

http://nrs.harvard.edu/urn-3:HUL.InstRepos:4725021

\section{Terms of Use}

This article was downloaded from Harvard University's DASH repository, and is made available under the terms and conditions applicable to Other Posted Material, as set forth at http:// nrs.harvard.edu/urn-3:HUL.InstRepos:dash.current.terms-of-use\#LAA

\section{Share Your Story}

The Harvard community has made this article openly available.

Please share how this access benefits you. Submit a story.

Accessibility 
Peter Suber

\title{
A Bibliography of Works on Reflexivity
}

\author{
"I don't have to quote \\ anybody else to say what I \\ could say for myself."
}

--Anon.

\section{Section One: Introduction}

"Reflexivity" is the generic name for all kinds and species of circularity. It includes the self-reference of signs, the self-appplication of principles and predicates, the self-justification and self-refutation of propositions and inferences, the self-fulfillment and self-falsification of predictions, the self-creation and self-destruction of logical and legal entities, the self-augmentation and self-limitation of powers, circular reasoning, circular causation, cyclic and spiral recurrence, feedback systems, mutuality, reciprocity, and organic form. It includes the fallacious, the vicious, the trivial, and the question begging, but also the sound, the benign, the useful, and the inescapable. It ranges from the prosaic to the numinous, from the paradoxical to the self-evident, from science to religion. It is reality and appearance, native to the processes of the world and to our knowledge and discourse about them.

Because this diversity is unified by a shared structure, that structure deserves a more general name than "self-reference," which has frequently served in the past. Usage in logic and mathematics has already favored "reflexivity" as the general term, and usage in philosophy and the sciences is moving in that direction.

This bibliography is the first to attempt to cover the range of reflexivity. Only by trying to approach completeness have I realized how limited the final product is. When collecting citations over such a broad area one must make innumerable decisions at innumerable borderlines. The result is not only that many borderline citations are excluded, but that the ideal of completeness is shattered. No topic as broad and deep as reflexivity has sharp borders; instead those borders are set for different purposes at different places. My decisions for this bibliography have largely been made explicit. Hence, I can say with some precision what the scope of the bibliography is, but for the same reason I cannot be satisfied that I have captured everyone's idea of reflexivity.

Decisions to exclude citations have tended to be of three kinds. (1) Sometimes the works on a certain topic shade from a hard core of 
relevancy to marginal irrelevancy. For example, many works on the theory of types or the possibility of self-deception are strongly relevant while others are predominantly essays on irreflexive aspects of those topics. This kind of shading off occurs with virtually every sub-topic of reflexivity. (2) Sometimes the works of a certain type are excluded because their great number outweighs their limited pertinency. Either all would have to be included, diluting the strength of the bibliography, or blurring its focus, or arbitrary decisions would have to be made, distinguishing the less relevant of the little-relevant from the more relevant of the little-relevant. I found this to be the case with works on dialectical logic, organic form, systems theory, metaphilosophy, the (psychological or ontological) "self", recursive runction theory, the physics and astronomy (but not the 'theology') of rotary motion, the geometry of circles, spheres and related curves, mutuality in the law of contract, most of the law on renvoi, particular studies of physical feedback devices, and (most regrettably) much of the literature on Gödel's theorems. (3) Finally, some kinds of citations must be excluded, even though directly germane, because of their great abundance and because finding them in sufficient numbers would unduly delay the final draft or multiply the expenses of the compiler. This was not a consideration in my collection of citations, but it necessarily became a consideration in deciding which citations would be included in this printed version. Under this head I have unfortunately had to exclude works not in the English language, and English reviews of such works. I sincerely hope that I have laid a foundation on which others may build.

This scope was maintained for works published up to 1984. No attempt has been made to be as complete for more recent works.

Although it is incomplete, the bibliography is large. It is so large that it would be nearly useless without some form of index. I have adopted two methods of cross-referencing. First, I have picked 28 rubrics or sub-species of reflexivity that usefully classify most citations. They attempt to serve both as the major subdivisions of reflexivity, by theme, and as the broadest categories into which the citations fell, as it were, actuarially. The rubrics are:

Computer Science

Dissertations

Feedback

Freedom

Hermeneutic Circle

Heterological

History

Impredication 
Liar

Metaphysics

Omnipotence

Paradox

Petitio Principii

Reflexivity in Art

Reflexivity in Law

Reflexivity in Literature

Reflexivity in Natural Science

Reflexivity in Religion

Reflexivity in Social Science

Russell's Paradox

Self-Application

Self-Deception

Self-Fulfilling Prophecies

Self-Justification

Self-Reference

Self-Refutation

Theory of Types

Vicious Circle

The last quarter or so of the text of the bibliography (Section Three) consists of the rubrics in alphabetical order, with the surnames of authors arrayed under them, also in alphabetical order, indicating which citations in the main list (Section Two) are pertinent to that sub-topic. For some rubrics I added a word or phrase to the authors' names to indicate the specific angle of their attack on the sub-topic. In this way, one searching for works on the paradox of the liar looks at the names under the rubric "Liar". A more particular interest in discussions of Ushenko's "new" version of the liar paradox takes one to the parenthetical phrases following the authors' names.

I must emphasize that citations are provided with specifying phrases in this way, and listed under rubrics, often on account of connections or contents evident from their titles alone. This reason is simply that I cannot pretend to have read all the works in the bibliography. Hence, many citations may be devoted to Ushenko's liar, for example, and not be so indicated in the cross-reference lists. However, in many cases I have annotated works that do not seem, from their titles alone, to concern reflexivity at all.

For economy, works on the liar paradox, for example, are listed only under the rubric "Liar" and not also under the rubric "Paradox" unless there is an independent reason for the two listings. Only four reflexive paradoxes have rubrics to themselves: the Epimenides or liar, Grelling's or the heterological paradox, Russell's or the set paradox, 
and the paradox of omnipotence. Works on other reflexive paradoxes may be found by scanning for appropriate qualifying phrases in the "Paradox" rubric.

The second method of cross-referencing occurs within the main alphabetical list (Section Two) itself. Works about particular thinkers are listed under those thinkers. For example, Gregory Vlastos's essay on self-predication in Plato is listed under "Plato". Under "Vlastos" the reader will find a cross-reference to Plato.

In the main list, an author's own works are listed first, alphabetically by title, not chronologically. Any works devoted to that author are collected at the end of his or her space in the alphabetical sequence. When a work is on two or more thinkers, it is listed under the author's own name; under each of the subject thinkers there is a cross-reference back to the full citation. Works reviewed by others in the list are usually so noted in the citation itself. Co-authored works are listed in full only once, under the lead author, but a cross-reference back to the full-citation is listed under each co-author's name.

Finally, the reader should note that I have used strict alphabetization. Spaces and recapitalization within surnames are ignored. "McAardvark" would come after "Macaardvark", not before as some conventions have it. "De Aardvark", "Van Aardvark", and "Van der Aardvark" would be listed as if spelled "Deaardvark", "Vanaardvark", and "Vanderaardvark".

I wish to acknowledge my reliance upon two excellent bibliographies already published: that on the paradox of the liar in Robert L. Martin's THE PARADOX OF THE LIAR (q.v.), and that on self-fulfilling prophecies and their kin in Richard L. Henshel's "Self-Altering Predictions" (q.v.). I also wish to thank two hard-working student assistants, Bill Stark and Kevin Lesher, for their accurate typing of illegible $3^{\prime \prime} \times 5^{\prime \prime}$ cards onto disk, and two others, Marilyn Piety and Eric Larson, for their labor in completing incomplete citations and supplying omissions.

I apologize to authors and readers for omissions that remain, either by a 'borderline decision' or oversight. There are sure to be as many in the second category as in the first. Bibliographies of this size become boundless undertakings, and after one's deliberate decisions of scope have been made with a wincing confidence, one must face the decisions made by the running out of time and funds, and accept them. While the bibliography still grows at a scholarly pace needed for completeness and accuracy, this printed version is a snapshot of its adolescence.

Additions and corrections to the bibliography will be received with gratitude. I may be reached at the Department of Philosophy, Earlham College, Richmond, Indiana, 47374. 
Section Two: Alphabetical List of Citations

Abrams, M.H. NATURAL SUPERNATURALISM: TRADITION AND REVOLUTION IN ROMANTIC LITERATURE. Chapter 3: "The Circuitous Journey: Pilgrims and Prodigals;" Chapter 4: "The Circuitous Journey: Through Alienation to Reintegration;" Chapter 5: "The Circuitous Journey: From Blake to D.H. Lawrence." W.W. Norton and Co., 1971.

Achinstein, Peter, "Circularity and Induction," ANALYSIS, 23 (1963) 123-27.

Achinstein, Peter, "The Circularity of a Self-Supporting Inductive Argument," ANALYSIS, 22 (1962) 138-41.

[Achinstein], Black, Max, "Self-Support and Circularity: A Reply to

Mr. Achinstein's 'The Circularity of a Self-Supporting Inductive Argument," ANALYSIS, 23 (1962) 43-44.

Agassi, J., "Variations on the Liar's Paradox," STUDIA LOGICA, 15 (1964) 237-38.

Alexander, Peter, "Pragmatic Paradoxes," MIND, 59 (Oct. 1950) 536-38. (Based on essays by Cohen and O'Connor.)

Allaire, Edwin B. [See work listed under Descartes]

Allison, Henry E., "Bishop Berkeley's Petitio," THE PERSONALIST, 54 (1973) 232-45.

Alston, William, "Self-Warrant: A Neglected Form of Privileged Access," AMERICAN PHILOSOPHICAL QUARTERLY, 13, 4 (1976) 257-72.

Alston, William, "Some Remarks on Chisholm's Epistemology," NOUS, 14, 4 (Nov. 1980) 565-86. (On 'self-presenting propositions'.)

Alter, Robert. PARTIAL MAGIC: THE NOVEL AS A SELF-CONSCIOUS GENRE. University of California Press, 1975.

Altizer, Thomas. THE SEI.F-EMBODIMENT OF GOD. Harper and Row, 1977.

Altizer, Thomas. [See work listed under Nietzsche]

[Anaxagoras], See: Teloh, $\mathrm{H}$.

Anderson, Alan Ross. Review of Thomson's "On Some Paradoxes" '(q.v.), JOURNAL OF SYMBOLIC LOGIC, 29 (1964) 139-40.

Anderson, Alan Ross, "St. Paul's Epistle to Titus," in R. L. Martin (ed.), THE PARADOX OF THE LIAR (q.v.). 
Anderson, C. Anthony, "The Paradox of the Knower," JOURNAL OF PHILOSOPHY, 80,6 (June 1983) 338-55.

Anon., "Circuity of Liens -A Proposed Solution," COLUMBIA LAWREVIEW, 38 (1938) 1267-78.

Anon., "Circuity of Priority and Liens Under Section 67 (c) (1) of the Bankruptcy Act," YALE LAW JOURNAL, 66 (1957) 784.

Anon., "Logical Paradoxes, Puzzles, and Problems," DELAWARE VALLEY ANNOUNCER, 35 (1962) 30-31.

Anon., [Note], VIRGINIA LAW REVIEW, 15 (1928) 90. (On circular liens.)

Anon., [Note], HARVARD LAW REVIEW, 67 (1953) 358. (On circular liens.)

Anon., "Priorities Between Mortgages and Mechanics Liens," YALE LAW JOURNAL, 36 (1926) 129. (On circular liens.)

Anon., "Res Judicata and Jurisdiction: The Bootstrap Doctrine," HARVARD LAW REVIEW, 53 (1940) 652-660.

Anon., "The Three-Cornered Priorities Puzzle," VIRGINIA LAW REVIEW, 8 (1922) 550. (On circular priorities.)

Anscombe, G.E.M., "A Reply to Mr. C.S. Lewis's Argument That 'Naturalism' Is Self-Refuting," in her COLLECTED PHILOSOPHICAL PAPERS, vol. II: METAPHYSICS AND THE PHILOSOPHY OF MIND, University of Minnesota Press, 1981.

[Anselm], Davis, Stephen T., "Anselm and Question-Begging: A Reply to William Rowe's 'Comments on Professor Davis' "Does The Ontological Argument Beg the Question?"' INTERNATIONAL JOURNAL OF THE PHILOSOPHY OF RELIGION, 7 (1976) 448-57.

[Anselm], Davis, Stephen T., "Does The Ontological Argument Beg The Question?" INTERNATIONAL JOURNAL OF THE PHILOSOPHY OF RELIGION, 7 (1976) 433-42. (See review by Rowe, W.L., listed under Anselm.)

[Anselm], Devine, Phillip E., "Does St. Anselm Beg the Question?" PHILOSOPHY, 50, 193 (July 1975) 271-81.

[Anselm], Rowe, William L., "Comments on Professor Davis' 'Does The Ontological Argument Beg the Question?'" INTERNATIONAL JOURNAL OF THE PHILOSOPHY OF RELIGION,7 (1976) 443-47.

Apolloni, David. [See work listed under Plato]

[Aquinas], Donceal, Joseph F., "Transcendental Thomism," THE MONIST, 58 (Jan. 1974) 67-85.

Aqvist, Lennart, "How to Handle the Liar Paradox in Modal Logic With Sentential Quantifiers and its Own Truth Predicate," 
THEORETICAL LINGUISTICS, 9, 1 (1982) 111-29. Aqvist, Lennart, "The Protagoras Case: An Exercise in Elementary Logic for Lawyers," (pp. 211-24) in Wlodzimierz Rabinowicz (ed.), TANKAR OCH TANKEFEL. Uppsala, 1981.

Archibald, Peter, "Self-Fulfilling Prophecy," PSYCHOLOGICAL BULLETIN, 81 (1973) 74-84. [Aristotle], Greene, Murray, "Aristotle's Circular Movement As A Logos Doctrine," REVIEW OF METAPHYSICS, 19 (1965) 115-32.

[Aristotle], See: O'Brien, J.F.; Woods, J. and Walton, D. Armstrong, D.M., "Self-Fulfilling Beliefs," (pp. 180-83), Chapter 12,

Section VI of his BELIEF, TRUTH, AND KNOWLEDGE. Cambridge University Press, 1973.

Arnheim, Rudolf. THE POWER OF THE CENTER: A STUDY OF COMPOSITION IN THE VISUAL ARTS. University of California Press, 1982.

[Arrabal], DeLong-Tonelli, Beverly J., "Bicycles and Balloons in Arrabal's Dramatic Structure," MODERN DRAMA, 14 (1971) 205-09.

Ashby, W.R., "Principles of the Self-Organizing Dynamic System," JOURNAL OF GENERAL PSYCHOLOGY, 37 (1947) 125-28. Ashby, W.R., "Principles of the Self-Organizing System," in PROCEEDINGS OF THE WESTERN JOINT COMPUTER CONFERENCE (May 9-11, 1961), pp. 255-78.

Ashby, W.R., and Riguet, J., "The Avoidance of Over-Writing in Self-Organizing Systems," JOURNAL OF THEORETICAL BIOLOGY, 1 (1961) 431-39.

Ashworth, E.J., "Inconsistency and Paradox in Medieval Disputations," paper delivered orally at a convention of the American Philosophical Association, April 27, 1984, Cincinnati.

Ashworth, E.J. Review of R.L. Martin (ed.), THE PARADOX OF

THE LIAR (q.v.), HISTORIA MATHEMATICA, 1 (1974) 215-18.

Ashworth, E.J., "Thomas Bricot (d. 1516) and the Liar Paradox," JOURNAL OF THE HISTORY OF PHILOSOPHY, 15 (July 1977) $267-80$.

Ashworth, E.J., "Will Socrates Cross the Bridge? A Problem in Medieval Logic," FRANCISCAN STUDIES, 36 (1976) 75-84.

Attig, Thomas. [See work listed under Descartes]

Babcock, M.L. et al. SOME PRINCIPLES OF PRE-ORGANIZATION 
IN SELF-ORGANIZING SYSTEMS. Technical Report 2, Electrical Engineering Research Laboratory, Engineering Experiment Station, University of Illinois, Urbana, 1960.

[Bach, Johann Sebastian], See: Hofstadter, D.R.

Back, Allan Thomas. THE THEORY OF REDUPLICATION. Ph.D. Dissertation, University of Texas at Austin, 1979.

Bahm, Archie, "Systems Theory: Hocus Pocus or Holistic Science?" GENERAL SYSTEMS, 14 (1969) 175-77.

Bahnsen, Gregory Lyle. A RESOLUTION OF THE APPARENT PARADOX OF SELF-DECEPTION. Ph.D. Dissertation, University of Southern California, 1979.

Baker, Dorothy Zayetz. MYTHIC MASKS OF SELF-REFLEXIVE POETRY: A STUDY OF PAN AND ORPHEUS. University of North Carolina Press, 1986.

Baker, Thomas A. [See work listed under Nietzsche.]

Baldwin, Harold Westcott. THE LOGIC OF REFLEXIVE REFUTATIONS. Ph.D. Dissertation, University of Colorado, 1973.

Ball, Terence, "Dangerous Knowledge? The Self-Subversion of Social Deviance Theory," INQUIRY, 23, 4 (Dec. 1980) 377-95.

Ballew, Lynne, "Straight and Circular in Parmenides and the 'Timaeus'," PHRONESIS, 19 (1974) 189-209.

Ballew, Lynne. STRAIGHT AND CIRCULAR: A STUDY OF IMAGERY IN GREEK PHILOSOPHY. Assen: Van Gorcum, 1979.

Barbo, Francesca Rivetti. [See work listed under Gödel.]

Bar-Hillel, Y., "Discussion --The Revival of "The Liar'," PHILOSOPHY AND PHENOMENOLOGICAL RESEARCH, 8 (1947) 245-53.

Bar-Hillel, Y., "Do Natural Languages Contain Paradoxes?" STUDIUM GENERALE, 19 (1966) 391-97. (See Cargile, J.)

Bar-Hillel, Y., "More on Sentences, Statements, the Cogito, and the Liar," PHILOSOPHICAL STUDIES, 19 (1968) 55-57.

Bar-Hillel, Y., "New Light on the Liar," ANALYSIS, 18 (1957) 1-6. (See Cargile, J.)

Bar-Hillel, Y., "The Present State of the Problem of the Antinomies: The Semantical Antinomies," TARBITS, 12 (1940-41) 275-86.

Barker, John, "The Fallacy of Begging the Question," DIALOGUE, 15 (1976) 241-55. (See reply by Sanford, D.)

[Barthelme, Donald], See: McCaffery, L.

[Barthes, Roland], See: Jay, P.

Bartlett, Steven J., "Cognitive Skills in Philosophy: A Teacher's Guide," AITIA, 6, 3 (1978-79) 12-21. 
Bartlett, Steven J. CONCEPTUAL THERAPY: AN INTRODUCTION TO FRAMEWORK-RELATIVE EPISTEMOLOGY. St. Louis University, Studies in Theory and Behavior, 1983.

Bartlett, Steven J., "The Idea of a Metalogic of Reference," METHODOLOGY AND SCIENCE, 9, 3 (1976) 85-92.

Bartlett, Steven J. METALOGIC OF REFERENCE: A STUDY IN THE FOUNDATION OF POSSIBILITY. Max-Planck Institut, 1975.

Bartlett, Steven J., "A Metatheoretical Basis for Interpretations of Problem-Solving Behavior," METHODOLOGY AND SCIENCE, 11, 2 (1978) 58-85.

Bartlett, Steven J., "Narcissism and Philosophy," METHODOLOGY AND SCIENCE, 19, 1 (1986) 16-26.

Bartlett, Steven J., "Phenomenology of the Implicit," DIALECTICA, 29, 2-3 (1975) 173-88.

Bartlett, Steven J., "Philosophy as Conceptual Therapy," RESOURCES IN EDUCATION, May 1983, Identification No. ED224402.

Bartlett, Steven J., "Philosophy as Ideology," METAPHILOSOPHY, 17, 1 (Jan. 1986) 1-13.

Bartlett, Steven J., "Referential Consistency As A Criterion of Meaning," SYNTHESE, 52 (1982) 267-82.

Bartlett, Steven J., "Reflexive Prediction in Behavioral Science," Learning Cycle Series, ADAPT, Behlen Laboratories, University of Nebraska-Lincoln, 1977.

Bartlett, Steven J. A RELATIVISTIC THEORY OF PHENOMENOLOGICAL CONSTITUTION: A SELF-REFERENTIAL, TRANSCENDENTAL APPROACH TO CONCEPTUAL PATHOLOGY. Ph.D. Dissertation, Universite de Paris, 1970.

Bartlett, Steven J. Review of Boyle, Grisez, and Tollefsen, FREE CHOICE (q.v.), REVIEW OF METAPHYSICS, 32, 4 (June 1979) $738-40$.

Bartlett, Steven J., "Self-Reference, Phenomenology, and Philosophy of Science," METHODOLOGY AND SCIENCE, 13, 3(1980) 143-67.

Bartlett, Steven J., and Peter Suber (eds.). SELF-REFERENCE: REFLECTIONS ON REFLEXIVITY. Martinus Nijhoff, 1988.

Bartlett, Steven J., "Towards a Unified Concept of Reality," ETC.: A REVIEW OF GENERAL SEMANTICS, 32, 1 (1975) 43-49.

Bartlett, Steven J., "The Use of Protocol Analysis in Philosophy," METAPHILOSOPHY, 9, 3-4 (1978) 324-336.

Bartlett, Steven J., "Varieties of Self-Reference," in Steven J. Bartlett and Peter Suber (eds.), SELF-REFERENCE (q.v.). 
Bateson, Gregory, "A Theory of Play and Fantasy," PSYCHIATRIC RESEARCH REPORTS, 2 (1955) 39-51. (On self-referential character of play, compared with liar paradox.) Reprinted in J.S. Bruner, et al. (eds.), PLAY: ITS ROLE IN DEVELOPMENT AND EVOLUTION, Penguin Books, 1976.

Batten, Lynn M. [Co-authored work listed under Walton, D.N.]

Bausch, A. Review of Pap's "The Linguistic Hierarchy..." (q.v.), JOURNAL OF SYMBOLIC LOGIC, 22 (1957) 392-93.

Baylis, C. Review of Gregory's "Heterological and Homological" (q.v.), JOURNAL OF SYMBOLIC LOGIC, 17 (1952) 220.

Beach, Edward, "The Paradox of Cognitive Relativism: A Reply to Jack Meiland," METAPHILOSOPHY, 15, 1 (Jan. 1984) 1-15; typesetting errors corrected in 15, 3-4 (July-Oct. 1984) 157-171.

Beard, Robert W., "Semantic Theory and the Paradox of the Non-Communicator," PHILOSOPHICAL STUDIES, 17 (1966) 44-45.

Begley, W.E. VISNU'S FLAMING WHEEL: THE ICONOGRAPHY OF THE "SUDARSANA-CAKRA". New York University Press, 1973.

Behmann, H., "The Paradoxes of Logic," MIND, 46 (1937) 218-21. (See review by Langford, C.H.)

Benacerraf, Paul. [See work listed under Gödel]

Bendiner, R., "Quickie 'Results' Could Sway the Election," LIFE, 18 (Sept. 1964) 125-33.

Bennet, J. Review of Mackie's "Self-Refutation..." (q.v.), JOURNAL OF SYMBOLIC LOGIC, 30 (1965) 365-66.

Bennet, J. Review of Encarnacion's "On Ushenko's Version..." (q.v.), Ushenko's "A Note on the Liar..." (q.v.), Toms's "The Liar Paradox," (q.v.), Donnellan's "A Note on the Liar..." (q.v.), Ushenko's "An Addendum to the Note..." (q.v.), Toms's "Reply to a Note..." (q.v.), Rozeboom's "Is Epimenides Still Lying?" (q.v.), Huggett's "Paradox Lost," (q.v.), Whitely's "Let Epimenides Lie!" (q.v.), and Sibajiban's "Mr. Eric Toms on the Liar," (q.v.), JOURNAL OF SYMBOLIC LOGIC, 32 (1962) 108-12.

Benson, "Circuity of Lien -A Problem in Priorities," MINNESOTA LAW REVIEW, 19 (1935) 139.

Berger, Ralph. PSYCLOSIS: THE CIRCULARITY OF EXPERIENCE. San Fransisco: W.H. Freeman and Co., 1977.

[Berkeley, Bishop], See: Allison, H.E.

Berleant, Amold. [See work listed under Descartes]

Bertalanffy, Ludwig von. GENERAL SYSTEM THEORY: 
FOUNDATIONS, DEVELOPMENT, APPLICATIONS.

George Braziller, rev. ed., 1968. (First ed. 1951.)

Bertoldi, Eugene F., "Phenomenology of Phenomenology,"

CANADIAN JOURNAL OF PHILOSOPHY, 7, 2 (June 1977) 239-53.

Beth, E.W., "Some Remarks on Dr. Perelman's Essay on Logical Antinomies," MIND, 45 (1936) 487-88.

Bhattacharyya, S., "Symmetry, Transitivity, and Reflexivity," ANALYSIS, 19 (March 1959) 93-96.

Bhattacharyya, S., "Symmetry, Transitivity, and Reflexivity," JOURNAL OF THE PHILOSOPHICAL ASSOCIATION 7 (1960) 77-82.

Bhattacharyya, S., "Symmetry, Transitivity, and Reflexivity: Postscript," JOURNAL OF THE PHILOSOPHICAL ASSOCIATION 7 (1960) 83-84.

Biro, J.I., "Rescuing 'Begging the Question'," METAPHILOSOPHY, 8 (Oct. 1977) 257-71.

Black, Max. [See work listed under Achinstein, Peter]

[Blanshard, Brand], Garelick, Herbert M. "Blanshard and the Law of Contradiction," IDEALISTIC STUDIES, 4 (January 1974) 50-63. (On circularity and non-contradiction.)

Blauberg, I.V., V.N. Sadovsky, and E.G. Yudin, "Paradoxes of Systems Thinking," Chapter 13 of their SYSTEMS THEORY: PHILOSOPHICAL AND METHODOLOGICAL PROBLEMS. Moscow: Progress Publishers, 1977.

Bloch, Arthur. MURPHY'S LAW AND OTHER REASONS WHY THINGS GO WRONG. Three volumes. Price/Stern/Sloan, 1980-82.

Boas, George, "Cycles," DICTIONARY OF THE HISTORY OF IDEAS, I.621-27. Ed. Philip Wiener. N.Y.: Charles Scribner's Sons, 1973.

Bochenski, I.M., "Formalization of a Scholastic Solution of the Paradox of the Liar," in A. Menne (ed.), LOGICO-PHILOSOPHICAL STUDIES, pp. 64-66. D. Reidel, 1962.

Bonifacio, Armando F., "On Capacity Limiting Statements," MIND, 74 (1965) 87-88.

Boolos, George, "Provability, Truth, and Modal Logic," JOURNAL OF PHILOSOPHIC LOGIC, 9 (February 1980) 1-7.

Borges, Jorge Luis, "The Fearful Sphere of Pascal," in his LABYRINTHS, SELECTED STORIES AND OTHER WRITINGS. Donald A. Yates and James E. Irby (eds.). New Directions Publishing Co., 1964. 
[Borges Jorge Luis], See: Murillo, L.A.

Borkenau, Franz. END AND BEGINNING: ON THE GENERATIONS OF CULTURE AND THE ORIGINS OF THE WEST. Columbia University Press, 1981. (Defends "cyclic linearism" as a theory of history.)

Boudreau, H.L. [See work listed under Valle-Inclan] Bowden, L., "Heterologicality," ANALYSIS, 12 (1952), 77-81.

Bowerman, William R., "The Structure, Process and Function of Self-Referent Causal Attributions," JOURNAL FOR THE THEORY OF SOCIAL BEHAVIOR, 8 (March 1978) 45-75.

Boyle, Joseph M., Jr. THE ARGUMENT FROM SELF-REFERENTIAL CONSISTENCY: THE CURRENT DISCUSSION. Ph.D. Dissertation, Georgetown University, 1970.

Boyle, Joseph M. Jr., G. Grisez, and O. Tollefsen, "Determinism, Freedom, and Self-Referential Arguments," REVIEW OF METAPHYSICS, 26, 1, (Sept. 1972) 3-37.

Boyle, Joseph M. Jr., G. Grisez, and O. Tollefsen. FREE CHOICE: A SELF-REFERENTIAL ARGUMENT. University of Notre Dame Press, 1976.

Boyle, Joseph M. Jr., "Is Determinism Self-Refuting?" in Steven J. Bartlett and Peter Suber (eds.), SELF-REFERENCE (q.v.).

Boyle, Joseph M. Jr., "Self-Referential Inconsistency, Inevitable Falsity and Metaphysical Argumentation," METAPHILOSOPHY, 3, 1, (Jan. 1972) 25-42.

[Boyle, Grisez, Tollefsen], See: Bartlett, S.J.; Konyndyk, K.

Bradley, C.K., "The Paradoxes," ASTOUNDING SCIENCE FICTION, 53, (1954) 93-100.

[Bradley, F.H.], See: Rorty, A.D.

Brady, Ross T., "Reply to Priest on Berry's Paradox," THE PHILOSOPHICAL QUARTERLY, 34, 135 (April, 1984).

Braines, S.N., Napalkov, A.V., and Shreider, I.A., "Analysis of the Working Principles of Some Self-Adjusting Systems in Engineering and Biology," in PROCEEDINGS OF THE INTERNATIONAL CONFERENCE ON INFORMATION PROCESSING (ICIP), Paris. UNESCO House, 1959.

Braines, S.N., and Napalkov, A.V. CERTAIN PROBLEMS IN THE THEORY OF SELF-ORGANIZING SYSTEMS. Joint Publications Research Service Report 2177-N, U.S. Department of Commerce, 1960.

Brecht, George. [Co-authored work listed under Hughes, P.]

Brendel, Otto, J. SYMBOLISM OF THE SPHERE. A CONTRIBUTION TO THE HISTORY OF EARLIER GREEK 
PHILOSOPHY. E.J. Brill, and Humanities Press, 1977.

[Bricot, Thomas], See: Ashworth, E.J.

Briskman, Larry B., "Historicist Relativism and Bootstrap Rationality," MIND, 60, 4 (Oct. 1977) 509-39.

Brody, Michael, "On Circular Readings," in N.V. Smith (ed.)

MUTUAL KNOWLEDGE, pp. 133-46. Academic Press, 1982.

With comments by $\mathrm{K}$. Brown and R. Kempson and reply by

Brody, pp. 148-79.

Brown, D.B., "Paradox Without Tiers," ANALYSIS, 17 (1957) 112-118.

Brown, James M. [See work listed under Whitehead, A.N. and Russell, B.]

Brown, Marshall. THE SHAPE OF GERMAN ROMANTICISM. Cornell University Press, 1979. (On the theme of circularity of German Romanticism.)

Broyles, J.E. [See work listed under Gödel.]

Brush, Stephen G. [See work listed under Nietzsche.]

Bryant, John, "The Paradox of the Lawyers," MIDWEST JOURNAL OF PHILOSOPHY, 4 (1976) 1-2. (On Protagoras and Euathlus.)

Buck, Roger C. "Reflexive Predictions," PHILOSOPHY OF SCIENCE, 30 (1963) 359-374. (See review by Grünbaum, A.)

Buck, Roger C., "Rejoinder to Grünbaum's 'Comments on Professor Roger Buck's Paper "Reflexive Predictions"'," PHILOSOPHY OF SCIENCE, 30 (Oct. 1963) 373-74.

[Buck, Roger], Grünbaum, Adolf, "Comments on Professor Roger Buck's Paper 'Reflexive Predictions'," PHILOSOPHY OF SCIENCE, 30 (Oct. 1963) 370-72.

Buckner, D., and P. Smith, "Quotation and the Liar Paradox," ANALYSIS, 46, 2 (March 1986) 65-67.

Bunch, Bryan H. MATHEMATICAL FALLACIES AND PARADOXES. Van Nostrand Reinhold Co., 1982.

Bunge, William, "Goof --A Game to Begin All Games," RECREATIONAL MATHEMATICS MAGAZINE, No. 2, pp. 24-25.

Burge, Tyler, "Demonstrative Constructions, References, and Truth," JOURNAL OF PHILOSOPHY, 71, 7 (April 18, 1974). (On token-reflexive construction and tense logic).

Burge, Tyler, "Epistemic Paradox," JOURNAL OF PHILOSOPHY, 81, 1, (Jan. 1984) 5-29. (The liar paradox applied to thoughts and beliefs.)

Burge, Tyler, "Reasoning About Reasoning," PHILOSOPHIA: PHILOSOPHICAL QUARTERLY OF ISRAEL, 8, 4 (Dec. 
1978) 205-223.

Buridan, John. JOHN BURIDAN ON SELF-REFERENCE. Translated with introduction and commentary by G.E. Hughes. Cambridge University Press, 1982. (Chapter 8 of the SOPHISMATA, for which see, e.g., the next citation.)

Buridan, John. SOPHISMS ON MEANING AND TRUTH. Translated with introduction by T.K. Scott. N.Y. 1966.

[Buridan, John], See: Prior, A.N.

Burkholder, Peter M., "Petitio in the Strife of Systems," TULANE STUDIES IN PHILOSOPHY, 16 (1967) 19-31.

Burnaby Art Gallery (ed.). MYSTIC CIRCLE. Burnaby, British Columbia: Burnaby Art Gallery, 1973. (Catalog of an Exhibition)

Burnyeat, M.F., "Protagoras and Self-Refutation in Later Greek

Philosophy," PHILOSOPHICAL REVIEW, 85, 1 (Jan. 1976) 44-69.

Burnyeat, M.F., "Protagoras and Self-Refutation in Plato's "Theatetus'," PHILOSOPHICAL REVIEW, 85, 2 (April, 1976) 172-195.

Cairns, Grace E. PHILOSOPHIES OF HISTORY: MEETING OF EAST AND WEST IN CYCLE-PATTERN THEORIES OF HISTORY. Philosophical Library, 1962. Reprinted by Greenwood Press, 1971.

Calderwood, James L. TO BE AND NOT TO BE: NEGATION AND METADRAMA IN HAMLET. Columbia University Press, 1983.

[Calleja, Pi], See: Levi, B.

Callois, Roger, "Circular Time, Rectilinear Time," DIOGENES, 42 (1963) 1-13.

Cameron, S. [Co-authored work listed under Yovitts, M.]

Campbell, Joseph, "The Turning Wheel of Terror-Joy," Part I of Chapter 7 of his THE MASKS OF GOD: CREATIVE MYTHOLOGY,pp. 405-416. Viking Press, 1968.

Campbell, Morton Carlisle, "Protection Against Indirect Attack," in HARVARD LEGAL ESSAYS, Harvard University Press, 1934, pp. 3-37. (On circular liens.)

Cargile, James, "On Omnipotence," NOUS, 1 (1967) 201-05.

Cargile, James. PARADOXES: A STUDY IN FORM AND PREDICATION. Cambridge University Press, 1979.

Cargile, J., Review of Bar-Hillel's "New Light on The Liar" (q.v.), and 
Bar-Hillel's "Do Natural Languages..." (q.v.), JOURNAL OF SYMBOLIC LOGIC, 34 (1969) 645.

Cargile, J., Review of Geach's "Ryle on Namely Riders" (q.v.),

Fitzpatrick's "'Heterological' and Namely-Riders" (q.v.), Geach's "Namely Riders Again" (q.v.), JOURNAL OF SYMBOLIC LOGIC, 32 (1967) 408-409.

[Camap, Rudolf], See: Stegmuller, W.

Carrier, D., "On the Depiction of Figurative Representational Pictures

Within Pictures," LEONARDO, 12 (1979) 197-200.

Caws, Peter, "The Paradox of Induction and the Inductive Wager," PHILOSOPHY AND PHENOMENOLOGICAL RESEARCH, 22 (June 1962) 512-20.

Champlin, T.S., "Double Deception," MIND, 85 (January 1976) 100-02.

Champlin, T.S., "Self-Deception: A Reflexive Dilemma," PHILOSOPHY, 52, 20, (July, 1977) 281-99.

[Chardin, Teilhard de], See: O'Brien, J.F.

Chihara, Charles S. ONTOLOGY AND THE VICIOUS CIRCLE PRINCIPLE. Cornell University Press, 1973.

Chihara, Charles S., "The Semantic Paradoxes: A Diagnostic Investigation," PHILOSOPHICAL REVIEW, 88, 4 (Oct. 1979) $590-618$.

Chihara, Charles S., "Truth, Meaning, and Paradox," NOUS, 10, 2-3 (May-Sept. 1976) 305-12. (Response to Donald Davidson.)

Chihara, Charles S., "Wittgenstein's Analysis of the Paradoxes in his Lectures on the Foundation of Mathematics," PHILOSOPHICAL REVIEW, 86, 3 (July, 1977) 365-81.

Chihara, Charles S. [See work listed under Gödel]

[Chihara, Charles S.], See: Steiner, M.

Chinn, Ewing Y. [See work listed under Descartes.]

Chisholm, Roderick. THE FIRST PERSON: AN ESSAY ON REFERENCE AND INTENTIONALITY. Minnesota University Press, 1981.

Chisholm, Roderick. THEORY OF KNOWLEDGE. Prentice-Hall, 1966. (On 'self-presenting' states and propositions.)

[Chisholm, Roderick], See: Alston, W.

Chowdhry, K. and Theodore M. Newcomb, "The Relative Abilities of

Leaders and Nonleaders to Estimate Opinions in Their Own

Groups," JOURNAL OF ABNORMAL AND SOCIAL PSYCHOLOGY, 47 (1952) 51-57.

[Christ, Jesus], See: Sell, J.J.

Christensen, N.E., "On an Apparent Circularity in Some Definitions of Logical Truth," MIND, 66 (1957) 395-97. 
Church, Alonzo, Review of Bradley's "The Paradoxes" (q.v.), JOURNAL OF SYMBOLIC LOGIC, 19 (1954) 236.

Church, Alonzo, Review of Geach's "Mr. Ill-named" (q.v.), JOURNAL OF SYMBOLIC LOGIC, 14 (1949) 136.

Church, Alonzo, Review of Geach's "On Insolubilia" (q.v.), JOURNAL OF SYMBOLIC LOGIC, 20 (1955) 192.

Church, Alonzo, Review of Koyre's The Liar" (q.v.), JOURNAL OF SYMBOLIC LOGIC, 11 (1946) 131.

Church, Alonzo, Review of Lawrence's "Heterology and Hierarchy" (q.v.), JOURNAL OF SYMBOLIC LOGIC, 15 (1950) 216-17.

Church, Alonzo, Review of Weinbergs's "A Possible Solution of the Heterological Paradox" (q.v.), JOURNAL OF SYMBOLIC LOGIC, 3 (1938) 46.

Church, Alonzo, "The Richard Paradox," THE AMERICAN MATHEMATICAL MONTHLY, 41 (1934) 356-61.

Churchland, Patricia Smith, "Is Determinism Self-Refuting?," MIND, 90, 357 (Jan. 1981) 99-101. (See review by Smith, J.W.)

Clark, Malcolm. "Circularity and Criticism," Part II, Chapter VI, 1, of his LOGIC AND SYSTEM: A STUDY OF THE TRANSITION FROM 'VORSTELLUNG' TO THOUGHT IN THE PHILOSOPHY OF HEGEL, pp. 194-97. Martinus Nijhoff, 1971.

Clark, W.A. [Co-authored work listed under Farley, B.G.]

Clegg, Jerry S. [See works listed under Nietzsche and Plato]

Coe, Rolf T. SACRED CIRCLES: TWO THOUSAND YEARS OF NORTH AMERICAN INDIAN ART. University of Washington Press, 1977.

Coder, David. [See work listed under Gödel.]

Cohen, David, "Hindi 'Apnaa': A Problem in Reference Assignment," FOUNDATIONS OF LANGUAGE, 10 (September 1973) 399-408.

Cohen, L.J., "Mr. O'Connor's 'Pragmatic Paradoxes'," MIND, 59 (1950) 85-87.

Cohen, L.J., "Why Do Cretans Have To Say So Much?" PHILOSOPHICAL STUDIES, 12 (1961) 72-78. (See review by Kanger, S.)

Cohen, Sybil. [See work listed under Ingarden]

[Coleridge, Samuel Taylor], See: Benzinger, J.; Fogle, R.H.

Colie, Rosalie L. PARADOXIA EPIDEMICA: THE RENAISSANCE TRADITION OF PARADOX. Princeton University Press, 1966. (Esp. Ch. 12: "'I am that I am': Problem of Self-Reference".)

Collier, Charles S., "Judicial Bootstraps and the General Welfare 
Clause," GEORGE WASHINGTON LAW REVIEW, 4 (1936) 211-242.

Collingwood, R.G. AN ESSAY ON METAPHYSICS, Chapter XII: "A

Psuedo-Science Refutes Itself," pp. 122-32, and Chapter XVI:

"Suicide of Positivistic Metaphysics," pp. 162-71. Chicago:

Henry Regnery Co., 1972.

Conway, Pierre H., "The Barber Paradox," LAVAL THEOLOGIQUE

ET PHILOSOPHIQUE, 18 (1962) 161-76.

[Coover, Robert], See: McCaffery, L.

Copleston, Frederick C., "The History of Philosophy: Relativism and

Recurrence," HEYTHROP JOURNAL, 14 (1973) 123-35.

[Copleston, Frederick], See: Harrison, C.

Corbin, Henry. CYCLICAL TIME AND ISMAILI GNOSIS. Routledge \& Kegan Paul, 1983.

Cork, Richard. VORTICISM AND ABSTRACT ART IN THE FIRST MACHINE AGE. Volume I: ORIGINS AND DEVELOPMENT; Volume II: SYNTHESIS AND DECLINE. University of California Press, vol. I, 1976; vol. II, 1977.

Cornforth, Maurice, "The Circularity and the Test of Dialectical Materialism," Chapter III.1.5 of his MARXISM AND THE LINGUISTIC PHILOSOPHY, pp. 782-84. International Publishers, 1965.

Cosentino, Dante A., "Self-Deception Without Paradox," PHILOSOPHY RESEARCH ARCHIVES, 6, 4 (1961).

Coval, Sam. SCEPTICISM AND THE FIRST PERSON. Methuen and Co., 1966.

Coval, Sam, "Self-Reference for Non-Selves," PHILOSOPHIA, 4 (October 1974) 469-83.

Cowan, J.L., "The Paradox of Omnipotence," ANALYSIS, Supplement, 25 (1965) 102-08.

Cowan, J.L., "The Paradox of Omnipotence Revisited," CANADIAN JOURNAL OF PHILOSOPHY, 3 (1974) 435-445.

Craig, William, "Divine Omniscience and Newcomb's Paradox," paper delivererd orally at a convention of the American Philosophical Convention, April 27, 1984, Cincinnati.

Crossley, John N. SETS, MODELS AND RECURSION THEORY. Humanities Press, 1965.

Crosthwaite, J. [Co-authored work listed under Priest, G.]

Csanyi, V., and G. Kampis, "Autogenesis: The Evolution of Replicative Systems," JOURNAL OF THEORETICAL BIOLOGY, 114 (1985) 303-321.

Cumming, Robert Denoon. STARTING POINT: AN INTRODUCTION TO THE DIALECTIC OF EXISTENCE. 
University of Chicago Press, 1979.

Cummins, Robert. [See work listed under Descartes]

Curry, B., "The Paradox of Kleene and Rosser," TRANSACTIONS OF THE AMERICAN MATHEMATICAL SOCIETY, 50 (1941) 454-516. (See review by Kalmer, L.)

Daemmrich, Horst S. [See work listed under Hoffmann]

Dahlstrom, Daniel O. [See work listed under Hegel]

Dalla Chiara, Maria Luisa, "Logical Self-Reference, Set Theoretical

Paradoxes and the Measurement Problem in Quantum Mechanics," JOURNAL OF PHILOSOPHIC LOGIC, 6 (August 1977) 331-347.

Daniels, Charles B., "Self-Deception and Interpersonal Deception," PERSONALIST, 55 (Summer 1974) 244-52.

Danquah, Joseph. [See work listed under Whitehead, A.N. and Russell, B.]

Danto, Arthur. [See work listed under Nietzsche.]

Dars, Celestine. IMAGES OF DECEPTION: THE ART OF TROMPE-L'OEIL. Phaidon, 1979.

David, H.A. [Co-authored work listed under John, J.A.]

Davis, Stephen T. [See works listed under Anselm]

Davis, William H., "Is Perspectivism Just Another Perspective?" JOURNAL OF THOUGHT, 13 (July 1978) 205-10.

Daya, "Symmetry, Transitivity, and Reflexivity," ANALYSIS, 19 (Oct. 1958) 7-11.

Daya, "Symmetry, Transitivity, and Reflexivity," JOURNAL OF THE PHILOSOPHICAL ASSOCIATION, 7 (1960) 71-76.

Daya, "Symmetry, Transitivity, and Reflexivity: Concluding Note," JOURNAL OF THE PHILOSOPHICAL ASSOCIATION, 7 (1960) 83-84.

Daye, Douglas Dunsmore, "Circularity in the Inductive Justification of Formal Arguments ("Tarko") in the Twelfth-Century Indian Jaina Logic," PHILOSOPHY EAST AND WEST, 29 (1979) 177-88.

Daye, Douglas Dunsmore, "Reflexivity and Metalanguage Games in Buddhist Causality," PHILOSOPHY EAST AND WEST, 25 (1975) 95-101.

De Cornulier, Benolt, "Paradoxical Self-Reference," LINGUISTICS AND PHILOSOPHY, 2 (1978) 435.

Dees, J. Gregory. [Co-authored work listed under Hart, J.A.]

De George, Richard, "Reason, Truth, and Context," IDEALISTIC 
STUDIES, 4 (Jan. 1974) 35-49. (On self-reference.)

De Laguna, T., "On Certain Logical Paradoxes," PHILOSOPHICAL REVIEW, 25 (1916), 16-27.

[DeMorgan, Augustus], See: Walton, D.

Denhard, Charles H. THE AUTOBIOGRAPHY OF A BOOK. H. Wolff

Book Mfg. Co., 1936.

Dennett, Daniel. [Co-edited work listed under Hofstadter, D.R.]

Denzin, Norman K., "The Self-Fulfilling Prophecy and Patient-Therapist Interaction." Paper presented at conference of the American Sociological Association, New York, 1966.

De-Rijk, L.M., "Some Notes on the Medieval Tract 'De Insolubilibus',

With the Edition of a Tract Dating From the End of the Twelfth

Century," VIVARIUM, 4 (November 1966) 83-115.

Derr, Patrick G., "Reflexivity and the Methodology of Scientific Research Programmes," THE NEW SCHOLASTICISM, 55, 4 (Autumn, 1981) 500-03.

[Descartes], Allaire, Edwin B., "The Circle of Ideas and the Circularity of the Meditations," DIALOGUE, 5 (1966) 131-53.

[Descartes], Attig, Thomas, "Descartes and Circularity: The

Precipitous Rush to Defense," MODERN SCHOOLMAN, 54 (1977) 368-78.

[Descartes], Berleant, Arnold, "On The Circularity of the Cogito," PHILOSOPHY AND PHENOMENOLOGICAL RESEARCH, 26, 3 (March 1966) 431-433.

[Descartes], Chinn, Ewing Y., "A Journey Around the Cartesian Circle," PHILOSOPHY RESEARCH ARCHIVES, 9 (1983) 279-92.

[Descartes], Cummins, Robert, "Epistemology and the Cartesian Circle," THEORIA, 41 (1975) 112-24.

[Descartes], Doney, Willis, "The Cartesian Circle," JOURNAL OF THE HISTORY OF IDEAS, 16 (1955) 324-38.

[Descartes], Dreisbach, Donald F., "Circularity and Consistency in Descartes," CANADIAN JOURNAL OF PHILOSOPHY, 8 (1978) 59-78.

[Descartes], Feldman, Fred, "Epistemic Appraisal and the Cartesian Circle," PHILOSOPHICAL STUDIES, 27 (Jan. 1975) 37-55.

[Descartes], Frankfurt, Harry G., "Memory and the Cartesian Circle," PHILOSOPHICAL REVIEW, 71 (Oct. 1962) 504-11. (See review by Nelson, J.O.)

[Descartes], Frankfurt, Harry G., "A Reply to Mr. Nelson's Comments on 'Memory and the Cartesian Circle'," DIALOGUE, 4 (1965) 92-95.

[Descartes], Kelly, Matthew J., "The Cartesian Circle: Descartes' 
Response to Scepticism," JOURNAL OF THOUGHT, 5,2 (April 1970) 64-71.

[Descartes], Kretzmann, Norman, "On Rose's 'Cartesian Circle',"

PHILOSOPHY AND PHENOMENOLOGICAL RESEARCH, 26 (1965) 90-92.

[Descartes], Markie, Peter. THE CARTESIAN CIRCLE. Ph.D.

Dissertation, University of Massachusettes at Amherst,

University Microfilms, 1977.

[Descartes], Nelson, John O., "In Defence of Descartes: Squaring a

Reputed Circle," DIALOGUE, 3 (1964) 262-72. (A reply to

Frankfurt, H.G.)

[Descartes], Odegard, Douglas, "Escaping the Cartesian Circle," AMERICAN PHILOSOPHICAL QUARTERLY, 21, 2 (April 1984) 167-74.

[Descartes], Rose, Lynn E., "The Cartesian Circle," PHILOSOPHY AND PHENOMENOLOGICAL RESEARCH, 26 (1965) 80-81.

(See review by Kretzmann, N.)

[Descartes], Rose, Lynn E., "Reply to Mr. Kretzmann's 'On Rose's "Cartesian Circle"'," PHILOSOPHY AND

PHENOMENOLOGICAL RESEARCH, 26 (1965) 93.

[Descartes], Smith, Michael P. A VIRTUOUS CIRCLE: DESCARTES'

QUEST FOR CERTAINTY IN THE MIDDLE

MEDITATIONS. Ph.D. Dissertation, University of North

Carolina at Chapel Hill, 1983.

[Descartes], Stubbs, A.C., "Bernard Williams and the Cartesian Circle," ANALYSIS, 40 (1980) 103-08.

[Descartes], Tlumak, Jeffrey, "Squaring the Cartesian Circle," SOUTHERN JOURNAL OF PHILOSOPHY, 16 (1978) 247-57.

[Descartes], Van Cleve, James, "Foundationalism, Epistemic Principles, and the Cartesian Circle," THE PHILOSOPHICAL REVIEW,88,1 (Jan. 1979) 55-91.

[Descartes], Welch, Robert S. DOUBT, CERTAINTY, AND THE CARTESIAN CIRCLE. Ph.D. Dissertation, University of Massachusetts, 1983.

[Descartes], Zirlin, Robert B. THE CARTESIAN CIRCLE. Ph.D Dissertation, Johns Hopkins University, 1980.

[Descartes], See: Prior, A.N.; Rorty, A.O.; Scheier, C.A.; Sibajiban

Desmonde, William H. [See work listed under Gödel.]

Detlefsen, Michael. [See work listed under Gödel.]

Devine, Phillip E. [See work listed under Anselm]

[Dilthey, Wilhelm], See: Maraldo, J.C.

Dingler, H., "On Definitions That Contain Themselves as Determinants," METHODOS, 2 (1950-51) 296-98. 
Dominian, Jack. CYCLES OF AFFIRMATION. London: Darton, Longman and Todd, 1975.

Donceal, Joseph F. [See work listed under Aquinas]

Doney, Willis. [See work listed under Descartes]

Donnellan, Keith, "Categories, Negation, and the Liar Paradox," in

R.L. Martin (ed.), PARADOX OF THE LIAR (q.v.).

Donnellan, Keith, "A Note on the Liar Paradox," PHILOSOPHICAL REVIEW, 66 (1957) 394-97. (See review by Bennet, J.)

Dowden, Bradley H. A THEORY OF TRUTH: THE LIAR PARADOX. Ph.D Dissertation, Stanford University, 1980.

Drange, Theodore, "The Paradox of the Non-Communicator," PHILOSOPHICAL STUDIES, 15 (1964) 92-96.

Drange, Theodore, "The Paradox Defended," PHILOSOPHICAL STUDIES, 18 (1967) 1-12. (Paradox of the non-communicator.) (See review by Dunn, M.J.)

Drange, Theodore, "Paradox Regained," PHILOSOPHICAL STUDIES, 20 (June 1969) 61-64.

Dreisbach, Donald F. [See work listed under Descartes]

Driscoll, John A. [See work listed under Plato]

Duff-Forbes, D.R. [See work listed under Plato]

Dulst, Dick Van. REFLEXIVE AND SUPERREFLEXIVE BANACH SPACES. Amsterdam: Mathematisch Centrum, 1978.

Dumitriu, Anton, "The Logico-Mathematical Antinomies: Contemporary and Scholastic Solutions," INTERNATIONAL PHILOSOPHICAL QUARTERLY, 14, 3 (Sept. 1974) 309-28.

Dumitriu, Anton. [See work listed under Wittgentstein.]

Dunham, T.C. [See work listed under Grillparzer]

Dunn, M.J., "Drange's Paradox Lost," PHILOSOPHICAL STUDIES, 18 (1967) 94-95.

[Dworkin, Ronald], Farago, John, "Judicial Cybernetics: The Effects of Self-Reference on Dworkin's Rights Thesis,"VALPARAISO UNIVERSITY LAW REVIEW, 14 (1980) 371-425.

Dyson, M. [See work listed under Plato.]

- E -

Eckel, Michael D., "Bhavaviveka and the Early Madhyamika Theories of Language," PHILOSOPHY EAST AND WEST, 28 (July 1978) 323-37.

Edidin, Aron, "Bootstrapping Without Boots," in John Earman (ed.), TESTING SCIENTIFIC THEORIES, University of Minnesota Press, 1983. (A response to Glymour, C.)

Eigen, Manfred, and Peter Schuster. THE HYPERCYCLE: A 
PRINCIPLE OF NATURAL SELF-ORGANIZATION. Springer-Verlag, 1979.

Elgin, C.Z., "The Impossibility of Saying What is Shown," THE SOUTHERN JOURNAL OF PHILOSOPHY, 16 (Spring 1978) 617-27.

Eliade, Mircea. THE MYTH OF THE ETERNAL RETURN. Pantheon Books, 1954.

Eliot, T.D., "Reactions to Predictive Assumptions," AMERICAN SOCIOLOGICAL REVIEW, 2 (August 1937) 508-14.

Elliott, Lisa. THREE PARADOXES OF FICTION: A STUDY IN THE LOGIC OF FICTIONAL LANGUAGE. Ph.D. Dissertation, Columbia University, 1980

Emerson, Ralph Waldo, "Circles," Essay X of his ESSAYS, FIRST SERIES. Often reprinted, e.g. EMERSON'S ESSAYS; FIRST AND SECOND SERIES COMPLETE IN ONE VOLUME, pp. 212-28. Thomas Y. Crowell Co., 1926.

[Emerson], Witemeyer, H.H., "Line and Round in Emerson's Uriel,"

PUBLICATIONS OF THE MODERN LANGUAGE

ASSOCIATION, 82 (March 1967) 98-103.

[Empedocles], Long, A.A., "Empedocles' Cosmic Cycle in the 'Sixties'," (pp. 397-425) in A.P.D. Mourelatos (ed.), THE

PRE-SOCRATICS, Anchor Books, 1974.

[Empedocles], O'Brien, D. EMPEDOCLES' COSMIC CYCLE.

Cambridge University Press, 1969.

Enc, Berent, "Spiral Dependence Between Theories and Taxonomy," INQUIRY, 19 (1976) 41-71.

Encarnacion, J. "On Ushenko's Version of the Liar Paradox," MIND, 64 (1955) 99-100. (See review by Bennet, J.)

Englebretsen, George, F., "The Incompatibility of God's Existence and Omnipotence," SOPHIA, 10 (1971) 28-31. (See comments by Londey, D., King-Farlow, J., and Miller, B.)

Epstein, David G., "Circuity of Priority Problems," in his DEBTOR-CREDITOR LAW IN A NUTSHELL, pp. 115-16. West Publishing Co., 2d ed. 1980.

[Escher, M.C.], Ernst, Bruno. THE MAGIC MIRROR OF M.C. ESCHER. Random House, 1976.

[Escher, M.C.], See: Hofstadter, D.R.

[Euathlus], (Note: this name is sometimes spelled Eulathus) See: Bryant, J.; Lenzen, W.; Goossens, W.K.

[Eudoxus], Maula, E., Kasanen, E., and Mattila, J., "The Spider in the

Sphere, Eudoxus' 'Arachne'," PHILOSOPHIA, 5 (1975-76) 225-57.

Evans, Donald D. THE LOGIC OF SELF-INVOLVEMENT: A 
PHILOSOPHICAL STUDY OF EVERYDAY LANGUAGE WITH SPECIAL REFERENCE TO THE CHRISTIAN USE OF LANGUAGE ABOUT GOD AS CREATOR. S.C.M. Press, 1963.

Evans, E., "On Some Semantic Illusions," MIND, 63 (1954) 203-18. (See review by Thomson, J.F.)

Everitt, N., "A Problem for the Eliminative Materialist," MIND, 40 (1981) 428-34. (See review by Smith, J.W.)

- F -

Falletta, Nicholas. THE PARADOXICON. Doubleday and Co., 1983. Farago, John. [See work listed under Dworkin]

Farber, Edward, "Concentric Circles and Chemistry," SMITHSONIAN JOURNAL OF HISTORY, 2 (1967) 31-42.

Faris, William G. SELF-ADJOINT OPERATORS. Springer-Verlag. 1975.

Farley, B.G., "Self-Organizing Models for Learned Perception," in Yovitts, M.C. and Cameron, S. (eds.), SELF-ORGANIZING SYSTEMS, (q.v.), 1960.

Farley, B.G., and Clark, W.A., "Simulation of Self-Organizing System by a Digital Computer," I.R.E. TRANSATIONS ON INFORMATION THEORY, 4 (1955) 76-84.

Farrel, P.M., "Evil and Omnipotence" MIND, 67 (1958) 399-403.

Feldman, Fred. [See work listed under Descartes]

Filmer, Paul, "Sociology and Sound Stratification: Issues of Reflexivity and Tradition," in Barry Sandywell et al. PROBLEMS OF REFLEXIVITY AND DIALECTICS (q.v.), pp. 148-64. Routledge and Kegan Paul, 1975.

Fingarette, Herbert, "The Problem of the Self in the Analects," PHILOSOPHY EAST AND WEST, 29 (April 1979) 129-40.

Finkelstein, Maurice, "Further Notes on Judicial Self-Limitation," HARVARD LAW REVIEW, 39 (1925) 221.

Finkelstein, Maurice, "Judicial Self-Limitation," HARVARD LAW REVIEW, 37 (1924) 338.

Finnis, J.M., "Scepticism, Self-Refutation, and the Good of Truth," in Peter Hacker and Joseph Raz (eds.), LAW, MORALITY, AND SOCIETY: ESSAYS IN HONOUR OF H.L.A. HART, pp. 247-67. Oxford University Press, 1977.

Fish, Stanley Eugene. SELF-CONSUMING ARTIFACTS: THE EXPERIENCE OF SEVENTEENTH CENTURY LITERATURE. University of California Press, 1972.

Fishkin, James, "Justifying Liberty: The Self-Reflective Argument," 
paper delivered orally at a conference on Applied Philosophy, April 13, 1985, Bowling Green State University.

Fitch, Frederic Brenton, "Comments and a Suggestion," in R.L. Martin (ed.), THE PARADOX OF THE LIAR (q.v.).

Fitch, Frederic Brenton, "Excluded Middle and the Paradoxes," paper delivered orally at a conference of the Association for Symbolic Logic, New York City, 1975.

Fitch, Frederic Brenton, "Formalized Self-Reference," in Steven J. Bartlett and Peter Suber (eds.), SELF-REFERENCE (q.v.).

Fitch, Frederic Brenton, "On God and Immortality," PHILOSOPHY AND PHENOMENOLOGICAL RESEARCH, 8 (1948) 688-693.

Fitch, Frederic Brenton, "A Goedelized Formulation of the Prediction Paradox," AMERICAN PHILOSOPHICAL QUARTERLY, 1 (April 1964) 161-64.

Fitch, Frederic Brenton, "A Method for Avoiding the Curry Paradox," in Nicholas Rescher et al. (eds.), ESSAYS IN HONOR OF CARL G. HEMPEL, pp. 255-65. D. Reidel Pub. Co., 1969.

Fitch, Frederic Brenton, "The Perfection of Perfection," THE MONIST, 47 (1963) 466-71.

Fitch, Frederic Brenton, "Remarks on the Theory of Types," MIND, 56 (1946) 184.

Fitch, Frederic Brenton, "Self-Reference in Philosophy," MIND, 55 (1946) 64-73. Reprinted, slightly revised, as Appendix C to his SYMBOLIC LOGIC, q.v., pp. 217-225. (See review by Mostowski, A.)

Fitch, Frederic Brenton, "Self-Referential Relations," Actes du Xieme congres international de philosophie, (Amsterdam), 14 (1953) 121-27. (See review by Prior, A.N.)

Fitch, Frederic Brenton. SYMBOLIC LOGIC. Ronald Press, 1952.

Fitch, Frederic Brenton, and R.J. Orgass, "A Theory of Computing Machines," STUDIUM GENERALE, 22 (1969) 83-104.

Fitch, Frederic Brenton, and R.J. Orgass, "A Theory of Programming Languages," STUDIUM GENERALE, 22 (1969) 113-36.

Fitch, Frederic Brenton, "Universal Metalanguages for Philosophy," REVIEW OF METAPHYSICS, 17 (1964) 369-402.

Fitzpatrick, P.J., "'Heterological' and Namely-Riders," ANALYSIS, 22 (1961) 18-22. (See review by Cargile, J.)

Foerster, Heinz von. CYBERNETICS, CIRCULAR CAUSAL, AND FEEDBACK MECHAMISMS IN BIOLOGICAL AND SOCIAL SYSTEMS. Transactions of the Conference on Cybernetics. N.Y.: Josiah Macy, Jr. Foundation, 1949-55.

Foerster, Heinz von, "Cybernetics of Cybernetics," pp. 5-8 of Klaus 
Krippendorf (ed.), COMMUNICATION AND CONTROL IN SOCIETY, Gordon and Breach, 1979.

Foerster, Heinz von, OBSERVING SYSTEMS. Intersystems, 1981. (Includes a calculus of infinite regression to cope with certain problems of self-reference.)

Fox, Richard, "Philosophy and Self-Reference," PHILOSOPHY IN CONTEXT, 4 (1975) 28-36.

Frank, Joseph. THE WIDENING GYRE: CRISIS AND MASTERY IN MODERN LITERATURE. Rutgers University Press, 1963.

Frankfurt, Harry G, "The Logic of Omnipotence," PHILOSOPHICAL REVIEW, 73 (1964) 262-63.

Frankfurt, Harry G. [See works listed under Descartes]

[Frege, Gottlob], See: Hudson, J.L. Sloman, A.

Frutas, E. [See work listed under Guillen]

Fumerton, Richard A., "The Paradox of Analysis," PHILOSOPHY AND PHENOMENOLOGICAL RESEARCH, 43, 4 (June 1983).

Füredy, Viveca Y.G.M. THE PLAY WITH A PLAY --WITHIN-THE-PLAY: A STRUCTURAL MODEL. Ph.D. Dissertation, Hebrew University, 1983.

$$
-\mathbf{G} \text { - }
$$

Gale, Richard M., "The Egocentric Particular and Token-Reflexive Analyses of Tense," PHILOSOPHICAL REVIEW, 73 (April 1964) 213-28.

[Galileo], See: Mintz, S.I.

Gardner, Martin, "Logical Paradoxes," ANTIOCH REVIEW, 23 (1963) 172-77.

Garelick, William P. [See work listed under Blanshard]

Garfinkel, Harold. STUDIES IN ETHNOMETHODOLOGY. Prentice-Hall, 1967. (Much on the reflexivity of the stance of the sociologist.)

Garner, Richard T., "A Non-Paradoxical Paradox," PHILOSOPHICAL REVIEW, 78 (1969) 249-51.

Garvin, Lucius, "The Paradox of Aesthetic Meaning," PHILOSOPHY AND PHENOMENOLOGICAL RESEARCH, 8 (September 1947) 99-106.

Garzilli, Enrico. CIRCLES WITHOUT CENTER: PATHS TO THE DISCOVERY AND CREATION OF SELF IN MODERN LITERATURE. Harvard University Press, 1972.

[Gass, William H.], See: McCaffery, L.

Geach, P.T., " Mr. Ill-named," ANALYSIS, 9 (1948) 14-16. (See 
review by Church, A.)

Geach, P.T., "Namely-Riders Again," ANALYSIS, 22 (1962) 92-94.

(See review by Cargile, J.)

Geach, P.T., "A Note on the Reflexive Paradoxes," PHILOSOPHICAL

REVIEW, 62 (1953) 427-28. (A reply to Toms, E.)

Geach, P.T., "Omnipotence," PHILOSOPHY, 48 (1973) 7-20.

Geach, P.T., "On Insolubilia," ANALYSIS, 15 (1955) 71-72.

Geach, P.T., "Ryle on Namely-Riders," ANALYSIS, 21 (1961) 64-67. (See review by Cargile, J.)

Geach, P.T., "Two Paradoxes of Russell's," JOURNAL OF PHILOSOPHY, 67 (February 26, 1970) 89-97.

[Geach, P.T.], See: Woods, J. and Walton, D.

Gellman, Jerome, "The Paradox of Omnipotence, and Perfection," SOPHIA, 14 (1975) 31-39.

Gelven, Michael. A COMMENTARY ON HEIDEGGER'S 'BEING AND TIME'. Harper \& Row, 1970. Section on hermeneutic circle, pp. 176-81.

Gendin, Sidney, "Omnidoing," SOPHIA, 6 (1967) 17-22.

George, L.C., "King Solomon's Judgment Expressing Principles of Discretion and Feedback in Legal Rules and Reasoning," HASTINGS LAW JOURNAL, 30 (1979) 1549-75.

Gewirth, Alan, "Can Men Change Laws of Social Science?" PHILOSOPHY OF SCIENCE, 21 (July 1954) 229-41.

Gibbons, Thomas Field. SELF-REFERENCE, PARADOX, AND CRITICAL RATIONALISM. Ph.D. Dissertation, Vanderbilt University, 1979.

Gill, S. [See work listed under Wordsworth.]

Gilmore, Grant, "Circular Priority Systems," YALE LAW JOURNAL, 71 (1961) 53-74.

Glymour, Clark, "Bootstraps and Probabilities," JOURNAL OF PHILOSOPHY, 77, 11 (Nov. 1980) 691-99. (See replies by Horwich, P. and Edidin, A.)

Goddard, Leonard, "True and Provable," MIND, 67 (1958) 13-31. (See review by Resnick, M.D.)

Goddard, Leonard. [Co-authored work listed under Goldstein, L.]

Gödel, Kurt. ON FORMALLY UNDECIDABLE PROPOSITIONS OF PRINCIPIA MATHEMATICA AND RELATED SYSTEMS. Translated by B. Meltzer. Basic Books, 1962.

[Gödel, Kurt], Barbo, Francesca Rivetti, "A Philosophical Remark on Gödel's Unprovability of Consistency Proof," NOTRE DAME JOURNAL OF FORMAL LOGIC, 9 (1968) 67-74.

[Gödel, Kurt], Benacerraf, Paul, "God, the Devil, and Gödel," THE MONIST, 51 (1967) 9-32. 
[Gödel, Kurt], Broyles, J.E., "Paradox and Argument," INTERNATIONAL LOGIC REVIEW, 8 (1977) 160-69.

[Gödel, Kurt], Chihara, Charles S., "On Alleged Refutations of Mechanism Using Gödel's Incompleteness Results," JOURNAL OF PHILOSOPHY, 64 (1972) 507-26.

[Gödel, Kurt], Coder, David, "Gödel's Theorem and Mechanism," PHILOSOPHY, 44 (1969) 234-37.

[Gödel, Kurt], Desmonde, William H., "Gödel, Non-deterministic Systems and Hermetic Automata," INTERNATIONAL PHILOSOPHICAL QUARTERLY, 11 (1971) 47-74.

[Gödel, Kurt], Detlefsen, Michael, "On Interpreting Gödel's Second Theorem," JOURNAL OF PHILOSOPHICAL LOGIC, 8 (1979) 297-313.

[Gödel, Kurt], Findlay, J., "Goedelian Sentences: A Non-Numerical Approach," MIND, 51 (1942) 259-65.

[Gödel, Kurt], Good, I.J., "Gödel's Theorem is a Red Herring," BRITISH JOURNAL OF PHILOSOPHY OF SCIENCE, 19 (1969) 357-58.

[Gödel, Kurt], Hanson, Norwood Russell, "The Gödel Theorem," NOTRE DAME JOURNAL OF FORMAL LOGIC, 2 (1961) 94-110.

[Gödel, Kurt], Hanson, W.H., "Mechanism and Gödel's Theorems," BRITISH JOURNAL OF PHILOSOPHY OF SCIENCE, 22 (1971) 9-16.

[Gödel, Kurt], Hutton, Anthony, "This Gödel is Killing Me," PHILOSOPHIA, 6 (1976) 135-44. (See reply by Lucas, J.R.)

[Gödel, Kurt], Nagel, Ernest, and James R. Newman. GÖDEL'S PROOF. New York University Press, 1958.

[Gödel, Kurt], Nagel, Ernest, and James R. Newman, "Gödel's Proof," SCIENTIFIC AMERICAN, 194 (1956) 71-84.

[Gödel, Kurt], Safir, Orin, "Concrete Forms --Their Application to the Logical Paradoxes and Gödel's Theorem," JOURNAL OF PHILOSOPHICAL LOGIC, 5 (1976) 133-54.

[Gödel, Kurt], Slezak, Peter, "Gödel's Theorem and the Mind," BRITISH JOURNAL OF PHILOSOPHY OF SCIENCE, 33 (1982) 41-52.

[Gödel, Kurt], Yourgrau, Wolfgang, "Gödel and Physical Theory," MIND, 78 (1969) 77-90.

[Gödel, Kurt], See: Hofstadter, D.R.; Johnstone, A.A.; Lucas, J.R.; Stone, R.; Stone-de Montpensier, R.; Tucker, J.

Goffman, Erving. FRAME ANALYSIS: AN ESSAY ON THE ORGANIZATION OF EXPERIENCE. Harper and Row, 1974.

Goldin, J., "On Honi the Circle-Maker: A Demanding Prayer," 
HARVARD THEOLOGICAL REVIEW, 56 (July 1963) 233-7. Goldstein, Gordon T. [Co-authored work listed under Yovitts, M.C.] Goldstein, Laurence, "Four Alleged Paradoxes in Legal Reasoning,"

CAMBRIDGE LAW JOURNAL, 38 (1979) 373-91.

Goldstein, Laurence, and Leonard Goddard, "Strengthened

Paradoxes," AUSTRALIAN JOURNAL OF PHILOSOPHY, 58, 3 (Sept. 1980) 211-221.

Goldstein, Laurence. [See work listed under Wittgenstein.]

Goldstick, D. [See work listed under Hume]

Good, I.J., "A Note on Richard's Paradox," MIND, 75 (1966) 431. (See review by Tucker, J.)

Good, I.J. [See work listed under Gödel.]

Goossens, W.K., "Eulathus and Protagoras," LOGIQUE ET ANALYSE 20 (1977) 67-75.

Gorsky, D.P., "Nonpredicative and Predicative Definitions," Section 1.9 of his DEFINITION: LOGICO-METHODOLOGICAL PROBLEMS, pp. 75-78. Progress Publishers, 1974.

Gould, Carol Steinberg. [See work listed under Plato.]

Grambs, David. WORDS ABOUT WORDS. McGraw Hill, 1984. (A dictionary of words used in writing about writing and language.)

Grave, S.A., "On Evil and Omnipotence," MIND, 65 (1956) 249-62.

[Greenaigh], See:

Brown, T.M.

Greene, Murray. [See work listed under Aristotle]

Gregory, J., "Heterological and Homological," MIND, 61 (1952)

85-88. (See review by Baylis, C.)

Grelling, Kurt, "The Logical Paradoxes," MIND, 45 (1936) 481-86.

(See review by Langford, C.H.)

[Grillparzer], Dunham, T.C., "Circle Image in Grillparzer's Libussa," GERMANIC REVIEW, 36 (May 1961) 125-36.

Grimm, Ruediger Hermann. [See work listed under Nietzsche] Grisez, Germain. [Co-authored work listed under Boyle, J.M.]

Grisez, Germain, "Sketch of a Future Metaphysics," NEW SCHOLASTICISM, 38 (1964) 311-40.

Grossman, A. [See work listed under Milton]

Grover, Dorothy, "Inheritors and Paradox," JOURNAL OF PHILOSOPHY, 74, 10 (Oct. 1977) 590-604.

Gruenberg, Barry, "The Problem of Reflexivity in the Sociology of Science," PHILOSOPHY OF THE SOCIAL SCIENCES, 8 (Dec.1978) 321-43.

Grünbaum, Adolf. [See work listed under Buck, R.C.]

Grunberg, Emile, and Franco Modigliani, "Reflexive Predictions," 
PHILOSOPHY OF SCIENCE, 32 (April 1965) 173-74. Guaspari, Daud Solovay, R.M., "Rosser Sentences," ANNALS OF MATHEMATICAL LOGIC, 16 (May 1979) 81-99.

[Guillen, Jorge], Frutas, E., "Circle and Its Rupture in the Poetry of Jorge Guillen," BOOKS ABROAD, 42 (Winter 1968) 33-6.

Gupta, Anil, "Truth and Paradox," JOURNAL OF PHILOSOPHICAL LOGIC, 11 (1982) 1-60.

[Gupta], Belnap, N., "Gupta's Theory of Truth," JOURNAL OF PHILOSOPHICAL LOGIC, 11 (1982) 103-16.

Haack, Susan, "Paradoxes," Chapter 8 of her PHILOSOPHY OF LOGICS, pp. 135-151. Cambridge University Press, 1978.

Haight, M.R. A STUDY OF SELF-DECEPTION. Harvester Press, 1980.

Hall, J. SELF-PREDICTION AND FREE WILL. Ph.D. Dissertation, Johns Hopkins University, 1975.

Hanson, Norwood Russell. [See work listed under Gödel]

Hanson, W.H. [See work listed under Gödel]

Harel, David et al., "Self-Reference Referenced, and Self-Referenced," COMMUNICATIONS OF THE ACM, 23, 12 (December 1980) 736-37. (Three letters to the editor on texts that cite themselves.)

Harman, Gilbert, "Reasoning and Evidence One Does Not Possess," MIDWEST STUDIES IN PHILOSOPHY, 5 (1980) 163-82.

Harries, Karsten, "The Infinite Sphere: Comments on the History of a Metaphor," JOURNAL OF THE HISTORY OF PHILOSOPHY, 13, 1 (Jan. 1975) 5-15.

Harris, R., "Self-Description and the Theory of Types," ANALYSIS, 28 (1968) 207-08.

Harris, R., "The Semantics of Self-Description," ANALYSIS, 27 (1967) 144.

Harrison, Craig, "Totalities and the Logic of First Cause Arguments," PHILOSOPHY AND PHENOMENOLOGICAL RESEARCH, 35, 1 (Sept. 1974) 1-19.

Hart, H.L.A., "Self-Referring Laws," in FESTSKRIFT TILLÄGNAD KARL OLIVECRONA, pp. 307-16. Stockholm: Kunglia Boktryckeriet, P.A. Norstedt and Söner, 1964. Reprinted in Hart's ESSAYS IN JURISPRUDENCE AND PHILOSOPHY, Oxford University Press, 1983, pp. 170-78.

Hart, John A. and J. Gregory Dees, "Paradox Regained: A Reply to Meyers and Stern," JOURNAL OF PHILOSOPHY, 71, 12 (June 
27, 1974) 367-72.

Hart, W.D., "Causation and Self-Reference," in Steven J. Bartlett and

Peter Suber (eds.), SELF-REFERENCE (q.v.).

Hart, W.D., "On Self-Reference," PHILOSOPHICAL REVIEW, 79 (1970) 523-28.

Hart, W.D., "Russell and Ramsey," PACIFIC PHILOSOPHICAL QUARTERLY, 64 (1983) 193-210.

Hatab, Lawrence J. [See work listed under Nietzsche]

Hawthorn, John. THE LIAR PARADOX AND THE THEORIES OF

TRUTH. Ph.D. Dissertation, McGill University, 1983.

Haynes, Richard Pierce. [See work listed under Plato]

Heap, James L., "Description in Ethnomethodology," HUMAN STUDIES, 3 (January 1980) 87-106.

[Hegel], Aboulafia, Mitchell. THE SELF-WINDING CIRCLE: A STUDY OF HEGEL'S SYSTEM. St. Louis: Green, 1982.

[Hegel], Dahlstrom, Daniel O., "Hegel's Principia," THE NEW SCHOLASTICISM, 55, 4 (Autumn, 1981) 421-37. (That Hegel's Logic is not viciously circular.)

[Hegel], Rockmore, Tom, "Hegel on Epistemological Circularity and Certainty," INTERNATIONAL PHILOSOPHICAL QUARTERLY, 21, 3 (Sept. 1981) 235-48.

[Hegel], Rockmore, Tom. HEGEL'S CIRCULAR EPISTEMOLOGY. Indiana University Press, 1986.

[Hegel], Yerkes, James, THE CHRISTOLOGY OF HEGEL, Section: "The Hermenteutic Circle," State University of New York Press, 1982.

[Hegel, G.W.F.], See: Scheier, C.-A. Shafer, I.H.

Heidegger, Martin. NIETZSCHE, vol. 2: THE ETERNAL RECURRENCE OF THE SAME. Trans. David Farrell Krell. Harper \& Row, 1984.

[Heidegger], Norman, Bart Ross. METHODOLOGY, TEMPORALITY AND REFLECTION: A CRITICAL EXAMINATION OF THE HERMENEUTIC CIRCLE IN MARTIN HEIDEGGER'S 'BEING AND TIME'. Ph.D. Dissertation, University of New Mexico.

[Heidegger, Martin], See: Maraldo, J.-C.; Spanos, W.V.; Gelven, M.

Heidelberger, Herbert, "The Self-Presenting," GRAZER PHILOSOPHISCHE STUDIEN, Band 7/8 (1979).

Helm, Paul, "Omnipotence and Change," PHILOSOPHY, 51 (1976) 454-61.

Henle, P., Review of Reach's "The Name Relation..." (q.v.), JOURNAL OF SYMBOLIC LOGIC, 4 (1939) 134.

Hennessey, W.J. ARTISTS LOOK AT ART. University of Kansas 
Press, 1978.

Henshel, Richard L., "Effects of Disciplinary Prestige on Predictive Accuracy: Distortions from Feedback Loops," FUTURES, 7 (April, 1975) 92-106.

Henshel, Richard L. ON THE FUTURE OF SOCIAL PREDICTION. Bobbs-Merrill, 1976.

Henshel, Richard L., "Scientific Status and Boundaries of the Self-Fulfilling Prophecy." Paper delivered orally at a conference of the American Sociological Association, San Francisco, 1975.

Henshel, Richard L., "Self-Altering Predictions," in J. Fowles (ed.), HANDBOOK OF FUTURES RESEARCH. Greenwood Press, 1978. Contains an excellent bibliography.

Henshel, Richard L. and Leslie W. Kennedy, "Self-Altering Prophecies: Consequence for the Feasibility of Social Prediction," GENERAL SYSTEMS, 18 (1973) 119-26.

Henshel, Richard L., "Sociology and Prediction," AMERICAN SOCIOLOGIST, 6 (August, 1971) 213-220.

Herzberger, H.G., "Naive Semantics and the Liar Paradox," JOURNAL OF PHILOSOPHY, 79,9 (September 1982) 479-97.

Herzberger, H.G., "Notes on Naive Semantics," JOURNAL OF PHILOSOPHICAL LOGIC, 11 (1982) 61-102.

Herzberger, H.G., "Paradoxes of Grounding in Semantics," JOURNAL OF PHILOSOPHY, 67 (March 26, 1970) 145-67.

[Hesse, Herman], See: Serrano, M. Shafer, I.H.

Hicks, J.C., "The Liar Paradox in Legal Reasoning," CAMBRIDGE LAW JOURNAL, 29 (1971) 275-91.

Hinman, Lawrence. [See work listed under Skinner, B.F.]

Hintikka, Jaakko, "Identity, Variables, and Impredicative Definitions," JOURNAL OF SYMBOLIC LOGIC, 21 (1958) 225-45. (See review by Jensen, R.)

Hintikka, Jaakko, "Remarks on a Paradox," ARCHIV FÜR-RECHTS UND SOZIALPHILOSOPHIE, 44 (1958) 514-16. (On parliamentary omnipotence.) (Reply to Tammelo, I.)

Hintikka, Jaakko, "Vicious Circle Principle and the Paradoxes," JOURNAL OF SYMBOLIC LOGIC, 22 (1957) 245-49. (See review by Jensen, R.)

Hirsch, E.D., Jr., "The Self-Confirmability of Interpretations," Chapter 5, Section A, of his VALIDITY IN INTERPRETATION,pp. 164-169. Yale University Press, 1967.

[Hobbes, Thomas], See: Mintz, S.I.

Hoerster, Norbert. [See work listed under Ross, A.] 
Hoffman, Joshua. [See work listed under Mavrodes, G.I.]

Hoffman, Joshua. [Co-authored work listed under Rosenkrantz, G.] Hoffman, Robert, "On Begging the Question At Any Time," ANALYSIS, 32 (Dec. 1971) 51.

[Hoffmann, E.T.A.], Daemmrich, Horst S., "Struggle For a New Vision of the Infernal Circle," Chapter 4, of his THE SHATTERED SELF: E.T.A. HOFFMAN'S TRAGIC VISION, pp. 39-46. Wayne State University Press, 1973. (On theme of circle and confinement in the Johannes Kreisler stories.)

Hofstadter, A., "On Semantic Problems," JOURNAL OF PHILOSOPHY, 35 (1938) 225-32. (See review by Nagel, E.)

Hofstadter, Douglas R., "Analogies and Metaphors to Explain Gödel's

Theorem," TWO-YEAR COLLEGE MATHEMATICS

JOURNAL, 13, 2 (March 1982) 98-114.

Hofstadter, Douglas R. GÖDEL, ESCHER, BACH: an ETERNAL

GOLDEN BRAID. New York: Basic Books, Inc., 1979.

Hofstadter, Douglas, R., "Metamagical Themas," SCIENTIFIC AMERICAN, 224, 1 (January 1981) 22-32. (On self-referential sentences.)

Hofstadter, Douglas R. "Metamagical Themas: About Nomic: A Heroic Game That Explores the Reflexivity of the Law," SCIENTIFIC AMERICAN, 246, 6 (June 1982) 16-28.

Hofstadter, Douglas R., "Metamagical Themas: Can Inspiration Be Mechanized?" SCIENTIFIC AMERICAN, 247, 3 (September 1982) 18-34.

Hofstadter, Douglas R., "Metamagical Themas: A Self-Referential Column About Last January's Column About Self-Reference," SCIENTIFIC AMERICAN, 246, 1 (January 1982) 16-28.

Hofstadter, Douglas R., "Metamagical Themas: Tripping the Light Recursive in LISP, the Language of Artificial Intelligence," SCIENTIFIC AMERICAN, 248 (March 1983) 22-29.

Hofstadter, Douglas R., "Metamagical Themas: On Viral Sentences and Self-Replicating Structures," SCIENTIFIC AMERICAN,247, 1 (January 1983).

Hofstadter, Douglas R. and Daniel Dennett (eds.). THE MIND'S I: FANTASIES AND REFLECTIONS ON SELF AND SOUL. Basic Books, 1981.

Hofstadter, Douglas, R., "Self-Reference in Perception and Cognition," Paper presented orally at Conference of the Society for Philosophy and Psychology, Chicago, April 5, 1981.

Hofstadter, Douglas R., "Who Shoves Whom Around Inside the Carenium? Or What is the Meaning of the Word 'I'?" Indiana University Computer Science Department Technical Report No. 
Suber

A Bibliography of Works on Reflexivity

130, July 1982.

Hofstadter, Douglas R., UNDERSTANDING UNDERSTANDING. SCIENTIFIC AMIERICAN, 19983.

Hollander, John. RHYME'S REASON: A GUIDE TO ENGLISH VERSE. Yale University Press, 1981. (Witty, self-exemplifying descriptions of verse forms, genres, and tropes.)

Hollister, W.W., "Conduct and the Circle," JOURNAL OF PHILOSOPHY, 50 (Jan. 29, 1953) 57-70.

Horwich, Paul, "The Dispensability of Bootstrap Conditions," JOURNAL OF PHILOSOPHY, 77, 11 (Nov. 1980) 699-702. (Reply to Glymour, C.)

Hoy, David Couzens. THE CRITICAL CIRCLE: LITERATURE AND HISTORY IN CONTEMPORARY HERMENEUTICS. University of Califormia Press, 1978.

Hudson, James L., "Frege's Way Out," [of Russell's Paradox], PHILOSOPHICAL RESEARCH ARCHIVES, 1 (1975).

Hugget, W. J., "Paradox Lost," ANALYSIS, 19 (1958) 21-23. (See review by Bennet, J.)

Hughes, Patrick, and George Brecht. VICIOUS CIRCLES AND INFINITY: A PANOPLY OF PARADOXES. Doubleday, 1975.

Hugly, Philip, "A Semantical Account of the Vicious Circle Principle," NOTRE DAME JOURNAL OF FORMAL LOGIC, 20 (July 1979) 595-98.

Hull, David L., "Certainty and Circularity in Evolutionary Taxonomy," EVOLUTION, 21 (1967) 174-89.

[Hume], Goldstick, D., "Hume's 'Circularity' Charge Against Inductive Reasoning," DIALOGUE, 11 (1972) 258-66.

[Hume], Kivy, Peter, "Hume's Standard of Taste: Breaking the Circle," BRITISH JOURNAL OF AESTHETICS, 7 (Jan. 1967) 57-66.

[Hume, David], See: Rorty, A.O.

Hunter, John F.M., "Asking Oneself," PHILOSOPHICAL INVESTIGATIONS, 1 (Summer 1978) 14-24.

Hupp, Jon A. [See co-authored work listed under Shoch, John.]

Hutton, Anthony. [See work listed under Gödel]

[Ingarden, Roman], Cohen, Sybil, "Ingarden's Benign Circle," DIALECTICS AND HUMANISM: THE POLISH PHILOSOPHICAL QUARTERLY, 4, 4 (1977).

[Isaye, Gaston], See: Moleski, M. 
Jackson, Frank, "Richard on Richard's Paradox," MIND, 80 (April,1971) 284-85.

Jacobi, George T. [Co-authored work listed under Yovitts, M.C.] Jacobs, Francis, "Circularity and Responsibility," PHILOSOPHY, 39 (1964) 268-74.

Jacobs, Jaap. [See work listed under Suber, P.]

Jacobson, Nolan Pliny. BUDDHISM AND THE CONTEMPORARY WORLD: CHANGE AND SELF-CORRECTION. Southern Illinois University Press, 1982.

Jaki, Stanley L. SCIENCE AND CREATION: FROM ETERNAL CYCLES TO AN OSCILLATING UNIVERSE. N.Y.: Science History Publishers, 1974.

Jameson, G. [See work listed under Parmenides]

Jantsch, E. THE SELF-ORGANIZING UNIVERSE: SCIENTIFIC AND HUMAN IMPLICATIONS OF THE EMERGING PARADIGM OF EVOLUTION. Pergamon Press, 1980.

Jaspers, Karl, "Exegesis in Circles," in his PHILOSOPHY, Vol. 3, pp. 129-130. University of Chicago Press, 1971.

Jay, Paul. BEING IN THE TEXT: SELF-REPRESENTATION FROM WORDSWORTH TO ROLAND BARTHES. Cornell University Press, 1985.

Jenkins, James W. SELF-CORRECTING PROBLEMS IN INVESTMENT MANAGMENT. Allyn and Bacon, 1974.

Jensen, R., Review of Hintikka's "Identity, Variables and...," (q.v.), JOURNAL OF SYMBOLIC LOGIC, 32 (1967) 258-59.

Jensen, R., Review of Hintikka's "Vicious Circle Principle and...," (q.v.), JOURNAL OF SYMBOLIC LOGIC, 32 (1967) 258-59.

[Jimenez, Juan Ramon], Olson, Paul R.. CIRCLE OF PARADOX: TIME AND ESSENCE IN THE POETRY OF JUAN RAMON JIMENEZ. Johns Hopkins University Press, 1967.

[Jodelle, Estienne], Reiss, T.T., "Jodelle's Cleopatre and the Enchanted Circle," YALE FRENCH STUDIES, 47 (1972) 199-210.

John, J.A., and F.W. Wolock, H.A. David. CYCLIC DESIGNS. United States Department of Commerce, Bureau of Standards, Government Printing Office, 1972.

Johnson, Oliver A., "Begging the Question," DIALOGUE, 6 (1967) 135-50. (See review by Williams, M.E.)

Johnson, Oliver, A., "To Beg the Question: A Reply," DIALOGUE, 7 (Dec. 1968) 461-68.

Johnson, Oliver A., "Circular Arguments," Chapter VII, Section 2 of his SKEPTICISM AND COGNITION, pp. 226-239. University 
of Califomia Press, 1978.

Johnstone, Albert A., "Self-Reference, The Double Life and Gödel," LOGIQUE ET ANALYSE, 24 (March 1981) 35-47.

Johnstone, Henry W., Jr., "Argumentum ad Hominem with and without

Self-Reference," in Steven J. Bartlett and Peter Suber (eds.),

SELF-REFERENCE (q.v.).

Johnstone, Henry W., Jr., "The Categorio-Centric Predicament,"

SOUTHERN JOURNAL OF PHILOSOPHY, 4 (1966) 207-220.

Johnstone, Henry W., Jr., "Persons and Self-Reference," JOURNAL

OF THE BRITISH SOCIETY FOR PHENOMENOLOGY, 1

(Jan. 1970) 46-54. (See comment by Mays, W.)

Johnstone, Henry W., Jr., "Persons and Self-Reference: Reply to Mr.

Mays," JOURNAL OF THE BRITISH SOCIETY FOR PHENOMENOLOGY," 1 (Oct. 1970) 66.

Johnstone, Henry W., Jr. PHILOSOPHY AND ARGUMENT. The

Pennsylvnia State University Press, 1959.

Johnstone, Henry W., Jr. THE PROBLEM OF THE SELF. The

Pennsylvania State University Press, 1970.

Johnstone, Henry W., Jr., "Self-Refutation and Validity," THE MONIST, 48, 4 (1964) 467-85; reprinted in his VALIDITY AND RHETORIC IN PHILOSOPHICAL ARGUMENT, q.v.

Johnstone, Henry W., Jr. VALIDITY AND RHETORIC IN PHILOSOPHICAL ARGUMENT: AN OUTLOOK IN TRANSITION. Dialogue Press of Man \& World, 1978.

Jones, Russell A. SELF-FULFILLING PROPHECIES: SOCIAL, PSYCHOLOGICAL, AND PHYSIOLOGICAL EFFECTS OF

EXPECTANCIES. Hillsdale, N.J.: L. Erlbaum Associates

(Distributed by Halsted Press), 1977.

Jørgensen, Jørgen, "On Kattsoff's Reflexions on Jørgensen's Reflexions

on Reflexivity," MIND, 64 (1955) 542.

Jørgensen, Jørgen, "Some Reflections on Reflexivity," MIND, 62

(1953) 289-300. Also printed in the DANISH YEARBOOK OF

PHILOSOPHY, 6 (1969) 29-39.

[Joyce, James], See: Murillo, L.A.

[Jung, C.G.], See: Serrano, M.; Shafer, I.H.

Kalmer, L., Review of Curry's "The Paradox of Kleene and Rosser," (q.v.), JOURNAL OF SYMBOLIC LOGIC, 11 (1946) 136-37.

Kanerva, Pentti. SELF-PROPAGATING SEARCH: A UNIFIED THEORY OF MEMORY. Ph.D. Dissertation, Stanford University, 1984. 
Kanger, S., Review of Prior's "Epimenides the Cretan" (q.v.), Cohen's "Why do Cretan's Have to..." (q.v.), and 7 others on indirect speech, JOURNAL OF SYMBOLIC LOGIC, 32 (1967) 549-550.

Kapadia, R., "Paradox Found," MIND, 83, 330 (April 1974) 296-97. (Reply to T. Steel.)

Kaplan, David, and Montague, Richard, "A Paradox Regained," NOTRE DAME JOURNAL OF FORMAL LOGIC, 1 (1980)

79-90.

Kasanen, E. [Co-authored work listed under Eudoxus]

Kattsoff, L.O., "Some Reflections on Reflexivity," MIND, 64 (I955) 96-98. (See review by Jørgensen, J.)

Katz, Bernard D., "Is the Causal Criterion of Event Identity Circular?" AUSTRALASIAN JOURNAL OF PHILOSOPHY, 56 (Dec. 1978) 225-29.

Kautsky, J.H., "Myth, Self-Fulfilling Prophecy and Symbolic Reassurance in the East-West Conflict," JOURNAL OF CONFLICT RESOLUTION, 9 (March 1965) 1-17.

Kawin, Bruce F. THE MIND OF THE NOVEL: REFLEXIVE FICTION AND THE INEFFABLE. Princeton University Press, 1982.

Keene, G.B., "Capacity-Limiting Statements," MIND, 70 (1981) 251-52.

Keene, G.B., "On the Logic of the Circularity of Logic," MIND, 84, 333 (Jan. 1975) 100-01.

Keene, G.B., "Self-Referent Inference and the Liar Paradox," MIND, 92, 367 (July 1983) 430-33.

Keene, G.B., "A Simple Solution to the Paradox of Omnipotence," MIND, 67 (1980) 74-75. (See review by Mayo, B.)

Kellenberger, J., "The Ineffabilities of Mysticism," AMERICAN PHILOSOPHICAL QUARTERLY, 16, 4 (Oct. 1979). (Four species of ineffability and their paradoxes.)

Keller, James A., "Foundationalism, Circular Justification, and the Levels Gambit," paper delivered orally at Convention of the American Philosophical Association, April 27, 1984, Cincinnati.

Kellman, Steven G. THE SELF-BEGETTING NOVEL. Columbia University Press, 1980.

Kellogg, "Priorities Puzzle Under The Ship Mortgage Act," WASHINGTON LAW REVIEW, 2 (1927) 117. (On circular liens.)

Kelly, M.J. [See work listed under Descartes]

Kelly, R.J. [Co-authored work listed under Sagarin, E.] 
Kennedy, Leslie W. [Co-authored work listed under Henshel, R.L.]

Kester, S.W., and G.A. Letchworth, "Communication of Teacher Expectations and Their Effects on Achievement and Attitudes," JOURNAL OF EDUCATIONAL RESEARCH, 66 (Oct. 1972) 51-55.

Khamara, Edward J., "In Defense of Omnipotence," PHILOSOPHICAL QUARTERLY, 28 (1978) 215-28.

[Kierkegaard, Søren], See: Stack, G. Spanos, W.V.

Killalea, J.N., "Primeness and Heterologicality," ANALYSIS, 14 (1953) 20-24. (See review by Orey, S.)

Kimball, Ralph B. SELF-OPTIMIIZING COMPUTER-ASSISTED TUTORING: THEORY AND PRACTICE. Stanford University Press, 1973.

King-Farlow, John, "God and the Stone Paradox: Comment III," SOPHIA, 10 (1971) 31-33. (Comment on Englebretsen, G.)

Kivy, Peter. [See work listed under Hume]

Kleene, S., and J. Rosser., "The Inconsistency of Certain Formal Logics," ANNALS OF MATHEMATICS, 36 (1935) 630-36.

(See Curry, B.)

Klinkowitz, Jerome. THE SELF-APPARENT WORD: FICTION AS LANGUAGE, LANGUAGE AS FICTION. Illinois University

Press, 1984.

Klossowski, Pierre. [See work listed under Nietzsche]

Knaster, Stephen, "Is Determinism Self-Defeating?" Paper delivered orally at Convention of American Philosophical Association, Columbus, Ohio, April 30, 1982.

Kneale, William C., "Russell's Paradox and Some Others," in George

W. Roberts (ed.), BERTRAND RUSSELL MEMORIAL VOLUME. Humanities Press, 1978.

Kocourek, A., "A First Rate Legal Puzzle: A Problem in Priorities," ILLINOIS LAW REVIEW, 29 (1935) 852.

Kohl, H.R., and Parsons, C., "Self-Reference, Truth, and Provability," MIND, 69 (1960) 69-73.

Konyndyk, Kenneth, Jr., "Rational Affirmation and Free Choice: A Study of 'Free Choice'," NEW SCHOLASTICISM, 53, 4 (Autumn 1979) 502-14. Review of Boyle, Grisez, Tollefsen (q.v.).

Kordig, Carl R., "Another Ethical Paradox," MIND, 78 (October 1969) $598-599$.

Kordig, Carl R., "Evolutionary Epistemology is Self-Referentially Inconsistent," PHILOSOPHY AND PHENOMENOLOGICAL RESEARCH, 42, 3 (March 1982) 449-50.

Kordig, Carl R., "Objectivity, Scientific Change, and Self-Reference," 
Suber

BTTON STUDIES IN THE PHILOSOPHY OF SCIENCE,

BOS 519-23, D. Reidel Publishing Co., 1970.

vol. 8, pp. "Some Statements are Immune to Revision," NEW Kordig, Carl R., "Som SICISM, 55, 1, (Winter 1981) 69-76.

SCHOLA "Perceiving That We Perceive," PHILOSOPHICAL Kosman, L.A.,' 84, 4 (Oct. 1975) 499-519.

REVIEW, "The Art of Underpinning," DIOGENES, (Winter Kowzan, Tadeusz,

1976) 67-92. "The Liar," PHILOSOPHY AND

Koyre, Alexander,

review by Church, A.)

Koyre, A., "Reply," PHILOSOPHY

RESEARCH, "On the Ethics of Constructing Communication,"

Krippendorff, Klaus, "On thesidential Address at the International

delivered orally association on Paradigm Dialogues, Honolulu,

May 23, 1985. (Long subsection on "The Self-Referential

Imperative.) "Paradox and Information," Chapter 2 (pp.

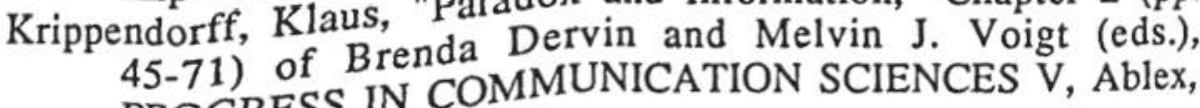

PROGRESS IN COMMUNICATION SCIENCES

1984.
Krishna, Daya, "The Self-Fulfilling Prophecy and the Nature of

Society." AMERICAN SOCIOLOGICAL REVIEW, 36 (Dec.

1971) 1104-07.

Krueger, Joe. [See work listed under Nietzsche]

Kvanvig, Jonathan L., "The Confusion over Foundationalism," oral presentation at convention of the American Philosophical Association, March 1985, Chicago. (In part, on "self-warrant foundationalism".)

Lambert, K., "On the Non-Communicator," PHILOSOPHICAL STUDIES, 17 (1966) 27-30.

Landsberg, P.T., "On Heterological Paradoxes," MIND, 62 (1953)

379-81. (See review by Orey, S.)

Langford, C.H., "On Paradoxes of the Type of the Epimenides," MIND, 56 (1947) 350.

Langford, C.H., "The Paradoxes," JOURNAL OF PHILOSOPHY, 47 (1950) 777-78.

Langford, C.H., Review of Behmann's "The Paradoxes of Logic,"

(q.v.), JOURNAL OF SYMBOLIC LOGIC, 2 (1937) 92. 
Langford, C.H., Review of Beth's "Some Remarks on Dr. Perelman's

Essay..." (q.v.), JOURNAL OF SYMBOLIC LOGIC, 2 (1937) 60.

Langford, C.H., Review of Grelling's "The Logical Paradoxes," (q.v.), JOURNAL OF SYMBOLIC LOGIC, 2 (1937) 60.

Langford, C.H., Review of Mclver's "More About Some Old Logical Puzzles," (q.v.), JOURNAL OF SYMBOLIC LOGIC, 6 (1941) 104.

Langford, C.H., Review of Ushenko's "A New Epimenides," (q.v.), JOURNAL OF SYMBOLIC LOGIC, 3 (1938) 51.

Langford, C.H., and Langford, M., "The Logical Paradoxes," PHILOSOPHY AND PHENOMENOLOGICAL RESEARCH, 21 (1959) 110-113.

Langford, M. [Co-authored work listed under Langford, C.H.]

Larson, Arthur, "The Self-Judging Clause and Self-Interest," JOURNAL OF THE AMERICAN BAR ASSOCIATION, 46 (1960) 729-31.

Lawrence, Irene (ed.). SELF-DEFINITION IN EARLY CHRISTIANITY: PROTOCOL OF THE 37TH COLLOQUY, JANUARY, 6 1980. Center for Hermenentical Studies in Hellenistic and Modern Culture, The Graduate Theological Union and the University of California, Berkeley, 1980.

Lawrence, N., "Heterology and Hierarchy," ANALYSIS, 10 (1950) 73-76. Reprinted in M. MacDonald (ed.) PHILOSOPHY AND ANALYSIS, (q.v.). (See reviews by Church, A. and Orey, S.)

Lawson, Hilary. REFLEXIVITY: THE POST-MODERN

PREDICAMENT. Open Court Press, 1986.

Lee, Edward N. [See work listed under Plato]

[Leibniz], See: Benziger, J.; Sinisi, V.F.

Lenzen, Wolfgang, "Protagoras versus Euathlus: Reflections on a So-Called Paradox," RATIO, 19 (Dec. 1977) 176-80.

[Lessing, Gotthold Ephraim], See: Higonnet, M.R.

Letchworth, G.A. [Co-authored work listed under Kester, S.W.]

Levi, Issac, "Induction as Self-Correcting According to Peirce," in D.H. Mellor (ed.), SCIENCE, BELEF AND BEHAVIOR: ESSAYS IN HONOR OF R.B. BRAITHWAITE. Cambridge University Press, 1980.

Levine, Michael, "Can There Be Self-Authenticating Experiences of God? A Reply to Robert Oakes," Paper delivered orally at Convention of American Philosophical Association, Columbus, Ohio, May 1, 1982. (With reply by Oakes.)

[Lewis, C.S.], See: Anscombe, G.E.M.

Lewis, David K. [See work listed under Scriven] 
Lightbody, Thomas P. AN EXAMINATION OF SOME RECENT APPROACHES TO THE LIAR PARADOX. Ph.D. Dissertation, Case Western Reserve University. 1977.

Lipman, Jean, and Richard Marshall. ART ABOUT ART. E.P. Dutton, 1978.

Llewelyn, John. BEYOND METAPHYSICS: THE HERMENEUTIC CIRCLE IN CONTEMPORARY CONTINENTAL PHILOSOPHY. Humanities Press, 1984.

Londey, David, "God and the Stone Paradox: Comment I," SOPHIA, 10 (1971) 23-25. (Comment on Englebretsen, G.)

[Lonergan, Bernard], See: Moleski, M.X.

Long, A.A., "The Stoics on World-Conflagration and Everlasting Recurrence," SUPPLEMENT TO THE SOUTHERN JOURNAL OF PHILOSOPHY, XXIII (1985).

Louisell, D.W., "Biology, Law, and Reason: Man as Self-Creator," AMERICAN JOURNAL OF JURISPRUDENCE, 16 (1971) 1.

Lorenzen, Paul. NORMATIVE LOGIC AND ETHICS. Bibliographisches Institut, 1969.

Löwith, Karl. [See work listed under Nietzsche]

Lucas, John Randolf. THE FREEDOM OF THE WILL. Oxford University Press, 1970.

Lucas, John Randolf, "Mechanism: A Rejoinder," PHILOSOPHY, 45 (1970) 149-51.

Lucas, John Randolf, "Mind, Machines, and Gödel," PHILOSOPHY, 36 (1961) 112-27.

Lucas, John Randolf, "Satan Stultified," THE MONIST, 52 (1968) $145-58$.

Lucas, John Randolf, "This Gödel is Killing Me: A Rejoinder," PHILOSOPHIA, 6 (1976) 145-48. (A rejoinder to Hutton, A.)

MacDonald, M. (ed.). PHILOSPHY AND ANALYSIS. Oxford University Press, 1954. (Much on heterologicality.) (See review by Orey, S.)

MacIver, A.M., "More About Some Old Logical Puzzles," ANALYSIS, 6 (1938) 63-68. (See review by Langford, C.H.)

Mackay, Alan, "Mandala Thinking," in David DeGrood, Dale Riepe, John Somerville (eds.), RADICAL CURRENTS IN CONTEMPORARY PHILOSOPHY, pp. 67-71. St. Louis: Warren H. Green, 1971.

Mackenzie, J.D., "Begging the Question in Dialogue," AUSTRALASIAN JOURNAL OF PHILOSOPHY, 62, 2 (June 
1984).

Mackenzie, J.D., "Why Do We Number Theorems?," AUSTRALASIAN JOURNAL OF PHILOSOPHY, 58, 2 (June 1980) 135-49. (Answer: to avoid circular proofs.)

Mackie, J.L., "Conditionally-Restricted Operations," NOTRE DAME JOURNAL OF FORMAL LOGIC, 2 (1961) 236-43.

Mackie, J.L., "Evil and Omnipotence," MIND, 64 (1955) 200-12.

Mackie, J.L., "Omnipotence," SOPHIA, I (1962) 13-25.

Mackie, J.L., "Self-Refutation -A Formal Analysis," PHILOSOPHICAL QUARTERLY, 14 (1964) 193-203. (See review by Bennet, J.)

Mackie, J.L. TRUTH, PROBABILITY, AND PARADOX: STUDIES IN PHILOSOPHICAL LOGIC. Oxford University Press, 1973. Mackie, J.L., "What Can We Leam From the Paradoxes?" CRITICA, 5 (Jan. 1971) 85-105.

Mackie, J.S., and J.J.C. Smart, "A Variant of the Heterological Paradox," ANALYSIS, 13 (1953) 61-65. (See review by Orey, S.)

Mackie, J.S., and J.J.C. Smart, "A Variant of the Heterological Paradox -A Further Note," ANALYSIS, 14 (1954) 146-49. (See review by Orey, S.)

Madge, Nicole. [Co-authored work listed under Rutter, Michael] [Malraux], Sonnenfeld, A., "Malraux and the Tyranny of Time: The Circle and the Gesture," ROMANIC REVIEW, 54 (Oct. 1963) 198-212.

Mandelbrot, Benoit. FRACTALS: FORM, CHANCE, AND DIMENSION. W.H. Freeman, rev. ed. 1982. (On self-similar curves.)

Mann, William E. [See work listed under Plato]

Manuel, Frank E. SHAPES OF PHILOSOPHICAL HISTORY. Stanford University Press, 1965. Chapter l: "The Wicked Dance in Circles...", Chapter 3: "Ixion's Wheel".

Marans, David, "A Note on Reflexiveness," NOTRE DAME JOURNAL OF FORMAL LOGIC, 16 (Oct. 1975) 501-06.

Mardiros, Anthony M., "A Circular Procedure in Ethics," PHILOSOPHICAL REVIEW, 61 (April 1952) 223-225.

Marino, Adrian, "Two Hermeneutical Circuits: Part/Whole and Analysis/Synthesis," DIALECTICS AND HUMANISM, 3, 2 (1976) 125-34.

Markie, Peter. [See work listed under Descartes]

Marshall, Geoffrey. CONSTITUTIONAL THEORY. Oxford University Press, 1971. (Much on legal omnipotence.)

Marshall, Geoffrey. PARLIAMENTARY SOVEREIGNTY AND THE 
COMMONWEALTH, Oxford University Press, 1957. (Much on legal omnipotence.)

Marshall, Geoffrey, "Parliamentary Sovereignty and the Language of Constitutional Limitation," JURIDICAL REVIEW, 67 (1955) 62-78.

Marshall, Geoffrey, "Parliamentary Sovereignty: A Recent Development," McGILL LAW JOURNAL, 12, 4 (1966-67) 523-27.

Marshall, Geoffrey, "What is Parliament? The Changing Concept of Parliamentary Sovereignty," POLITICAL STUDIES, 2, 3 (1954).

Marshall, James, Michael Peters, and Miles Shepheard, "Self-Refutation: Arguments Against Young's Epistemology," EDUCATIONAL PHILOSOPHY AND THEORY, 13, 2 (Oct. 1981) 43-50.

Marshall, Richard. [See co-authored work listed under Lipman, J.]

Martin, Richard M., "Self-Reference," Chapter Five of his PRAGMATICS, TRUTH AND LANGUAGE, pp. 55-71. D. Reidel Pub. Co., 1979.

Martin, Robert L., "Are Natural Languages Universal?" SYNTHESIS, 32 (April 1976) 271-92.

Martin, Robert L., "A Category Solution to the Liar," in R.L. Martin (ed.), PARADOX OF THE LIAR (q.v.).

Martin, Robert L., "On Grelling's Paradox," PHILOSOPHICAL REVIEW, 77 (July 1968) 321-31.

Martin, Robert L. THE PARADOX OF THE LIAR. Yale University Press, 1970. Contains excellent bibliography. (See review by Ashworth, E.J.)

Martin, Robert L. RECENT ESSAYS ON TRUTH AND THE LIAR PARADOX. Oxford University Press, 1984.

Martin, Robert L., and Woodruff, Peter W., "On Representing 'True-in-L' in L," PHILOSOPHIA, 5 (July 1975) 213-17.

Martin, Robert L., "Sommers on Denial and Negation," NOUS, 3 (1969) 219-26.

Martin, Robert L., "Toward a Solution to the Liar Paradox," PHILOSOPHICAL REVIEW, 76 (July 1967) 279-311.

Martin, R. M., "The Pragmatics of Self-Reference," essay number 5 in his PRAGMATICS, TRUTH AND METHOD. D. Reidel Publishing Co., 1979.

Martinich, A.P., "Conversational Maxims and Some Philosophical Problems," THE PHILOSOPHICAL QUARTERLY, 30, 120 (July 1980) 215-28. (Contains a solution to the liar.)

Marx, Wolfgang, "Epistemological Reflections on the Problem of 
Impredicative Conceptual Structures," RATIO, 17,1 (June 1975) 35-48.

Mates, Benson, "Philosophical Skepticism and the Logical Antinomies," PROCEEDINGS OF THE XIV INTERNATIONAL CONGRESS OF PHILOSOPHY.

Mates, Benson, "Two Antinomies," section of his SKEPTICAL ESSAYS, pp. 15-57. University of Chicago Press, 1981.

Mattila, J. [Co-authored work listed under Eudoxus]

Maturana, H.R., and F.J. Varela. AUTOPOIESIS AND COGNITION.

Boston Studies in the Philosophy of Science, vol. 42. D. Reidel, 1980.

Maula, E. [Co-authored work listed under Eudoxus]

Mavrodes, George I., "Selif-Referential Incoherence," AMERICAN PHILOSOPHICAL QUARTERLY, 22, 1 (Jan 1985).

Mavrodes, George I., "Some Puzzles Concerning Omnipotence," PHILOSOPHICAL REVIEW, 72 (1963) 221-23.

[Mavrodes], Hoffman, Joshua, "Mavrodes on Defining Omnipotence," PHILOSOPHICAL STUDIES, 35 (1979) 311-13.

[Mavrodes], Reichenbach, Bruce R., "Mavrodes on Omnipotence," PHILOSOPHICAL STUDIES, 37 (1980) 211-14.

Maynez, Eduardo Garcia, "Some Considerations on the Problem of Antinomies in the Law," ARCHIC FÜR RECHTS-UND SOZIALPHILOSOPHIE, 49, 1 (1963) 1-14.

Mayo, Bernard, "Mr. Keene on Omnipotence," MIND, (1961) 249-50. Mays, Wolfe, "Persons and Self-Reference: A Comment," JOURNAL OF BRITISH SOCIETY OF PHENOMENOLOGY, 1 (Jan. 1970) 55-6. (See review by Johnstone, H.W.)

McCaffery, Larry. THE METAFICTIONAL MUSE: THE WORK OF ROBERT COOVER, DONALD BARTHELME, AND WILLIAM H. GASS. University of Pittsburgh Press, 1982.

McKinsey, J.C.C. Review of Ushenko's "Undecidable Statement and..." (q.v.), JOURNAL OF SYMBOLIC LOGIC, 9 (1944) 97-98.

McLean, M.R., "The Unmakeable -Because-Unliftable Stone," CANADIAN JOURNAL OF PHILOSOPHY, 4 (1975) 717-21.

McNaughton, R. Review of Wang's "The Irreducibility of Impredicative Principles," (q.v.), JOURNAL OF SYMBOLIC LOGIC, 18 (1953) 265-66.

[McTaggart, J.E.M.], Roberts, Joy H., "Statements, Sentences and States of Affairs in McTaggart and in General," ERKENNTNIS, 15 (March 1980) 73-89.

Meager, R., "Heterologicality and the Liar," ANALYSIS, 16 (1956) 131-38. 
Meierding, Loren, "The Impossibility of Necessary Omnitemporal Omnipotence," INTERNATIONAL JOURNAL FOR PHILOSOPHY OF RELIGION, 11 (1980) 21-16.

Meiland, Jack W., "On the Paradox of Cognitive Relativism," METAPHILOSOPHY, 11, 2 (April 1980) 115-26. (See review by Beach, E.)

Meiland, Jack W., "Is Protagorean Relativism Self-Refuting?" GRAZER PHILOSOPISCHE STUDIEN, Band 9, 1979.

Mele, A.R., "Self-Deception," PHILOSOPHICAL QUARTERLY, 33, 133 (Oct. 1983) 366-77.

[Melville, Herman], Wiley, Margaret L., "Melville and Circularity," Essay VIII in her CREATIVE SCEPTICS. London: George Allen and Unwin, 1966.

Menger, K., "The New Logic," PHILOSOPHY OF SCIENCE, 4 (1937) 299-336. (See review by Quine, W.V.O.)

Menninger, Karl. LOVE AGAINST HATE. Chapter 5: Breaking the Vicious Circle (pp. 122-33). Harcourt, Brace and World, 1942.

Merleau-Ponty, Maurice, "Circular Dialectic," in his THEMES FROM THE LECTURES AT THE COLLEGE DE FRANCE, 1952-1980, pp. 57-60. Northwestern University Press, 1970.

Merton, Robert K., "The Self-Fulfilling Prophecy," ANTIOCH REVIEW, 8 (1948) 193-210.

Merton, Robert K., "The Self-Fulfilling Prophecy," Chapter 13 of his SOCIAL THEORY AND SOCIAL STRUCTURE. The Free Press, 1968.

Merton, Robert K., "The Unanticipated Consequences of Purposive Social Action," AMERICAN SOCIOLOGICAL REVIEW, 1 (Dec. 1936) 894-904.

[Meyers, Robert G], See: Hart, J.A. and Dees, J.G.

Michie, D., and Christopher Longuet-Higgens, "A Party-Game Model of Biological Replication," NATURE, 212, 5057 (October 1966) 10-12. (Self-referential sentences modeling biological replication.)

[Mill, John Stuart], See: Walton, D.

Miller, Arthur R., "Correct vs. 'Merely True' Act-Descriptions," INQUIRY, 17 (Winter 1974) 457-60.

[Miller, Arthur], Rayfield, David, "On Miller's Paradoxes and Circles," INQUIRY, 17 (Winter 1974) 461-64.

Miller, Barry, "God and the Stone Paradox: Comment II," SOPHIA, 10 (1971) 26-31. (Comment to Englebretsen, G.)

Miller, Myron Michael. THE LOGIC OF SELF-REFERRING KNOWLEDGE CLAIMS. Ph.D. Dissertation, New York University, 1977. 
Miller, Myron Michael, "The Pragmatic Paradox," in Steven J. Bartlett and Peter Suber (eds.), SELF-REFERENCE (q.v.).

Miller, Myron Michael, "Science and the Thumb-Chasing Game," paper delivered orally at the National Science Teachers Association Convention, Washington, D.C., March 31, 1968.

Miller, Richard W. [See work listed under Wittgenstein]

[Milton, John], Grossman, A., "Ring Pattern: Image, Structure and Theme in Paradise Lost," STUDIES IN PHILOLOGY, 68 (July 1971) 326-39.

Mintz, S.I., "Galileo, Hobbes, and the Circle of Perfection," ISIS, 43, pt.2, (1952) 98-100.

Mishkin, Paul J., "Prophecy, Realism, and the Supreme Court," JOURNAL OF THE AMERICAN BAR ASSOCIATION, 40 (Aug. 1954) 680-83 and 725-26.

Modigliani, Franco. [Co-authored work listed under Grunberg, E.]

Moleski, Martin X., S.J., "Retortion: the Method and Metaphysics of Gaston Isaye," INTERNATIONAL PHILOSOPHICAL QUARTERLY, 17, 1 (March 1977) 59-83.

Moleski, Martin X., S.J., "The Role of Retortion in the Cognitional Analyses of Lonergan and Polanyi," in Steven J. Bartlett and Peter Suber (eds.), SELF-REFERENCE (q.v.).

Molt, Peter, "Dates, Tenseless Verbs, and Token-Reflexivity," MIND, 82 (Jan. 1973) 73-85.

Montague, R. [Co-authored work listed under Kaplan, D.]

Morreall, John, "God as Self-Explanatory," THE PHILOSOPHICAL QUARTERLY, 30, 120 (July 1980) 206-14.

Mortensen, C. [Co-authored work listed under Priest, G.]

Morton, John. "On Recursive Reference," COGNITION, 4 (1976) 309. Mostowski, A., "Correction to the Paper 'Some Impredicative Definitions in the Axiomatic Set-Theory'," FUNDAMENTA MATHEMATICAE, 38 (1951-2) 238. (See review by Skolem, T.)

Mostowski, A., Review of Fitch's "Self-Reference in Philosophy," (q.v.), JOURNAL OF SYMBOLIC LOGIC, 11, (1946) 95-96.

Mostowski, A., "Some Impredicative Definitions in the Axiomatic Set-Theory," FUNDAMENTA MATHEMATICAE, 37 (1950-51) 111-124. (See review by Skolem, T.)

Mott, Peter, "Dates, Tenseless Verbs and Token Reflexivity," MIND, 82 (January 1973) 73-85.

Moulder, James, "Is Russell's Paradox Genuine?" PHILOSOPHY, 49, 189 (July 1974) 295-302.

Muller, G.H. Review of Yuting's "Two Semantical Paradoxes," (q.v.), JOURNAL OF SYMBOLIC LOGIC, 21 (1956) 380. 
Muller, Norbert, "Strategy and Reflexivity," in Leif Lewin (ed.), POLITICS AS RATIONAL ACTION, pp. 121-32. Reidel Pub. Co., 1980.

Munro, Colin R., "The Magical Roundabout of Conflict of Laws," JURIDICAL REVIEW, n.s. 23 (1978) 65-84.

Murillo, Louis Andrew. THE CYCLICAL NIGHT: IRONY IN JAMES JOYCE AND JORGE LUIS BORGES. Harvard University Press, 1968.

Myers, C. Mason, "Circular Explication," METAPHILOSOPHY, 9, 1 (Jan. 1978) 1-13.

Myers, C. Mason, "The Circular Use of Metaphor," PHILOSOPHY AND PHENOMENOLOGICAL RESEARCH, 26 (March 1966) 391-402.

Myhill, John, "Paradoxes," Essay 8 in Hughes Leblanc, Elliott Mendelson, and Alex Orenstein (eds.), FOUNDATIONS: LOGIC, LANGUAGE, AND MATHEMATICS, D. Reidel, 1984.

Myhill, John, "A System Which Can Define Its Own Truth," FUNDAMENTA MATHEMATICAE, 37 (1950) 190-92.

\section{$-\mathbf{N}$ -}

Naess, Arne, "Circularity of the Sceptic's Argument," Chapter 5, Section 7 of his SCEPTICISM, pp. 126-27. Routledge and Kegan Paul, 1968.

Nagel, Ernest, Review of Hofstadter's "On the Semantic Problems," (q.v.), JOURNAL OF SYMBOLIC LOGIC, 3 (1938) 90.

Nagel, Ernest, Review of Northrop's RIDDLES IN MATHEMATICS... (q.v.), JOURNAL OF SYMBOLIC LOGIC, 10 (1945) 21.

Nagel, Ernest. [See work listed under Gödel]

Nagel, Emest, and James R. Newman. [See works listed under Gödel.]

[Nagel], Nissen, Lowell, "Nagel's Self-Regulation Analysis of Teleology," THE PHILOSOPHICAL FORUM, 12, 2 (Winter 1980-81) 128-38.

Napalkov, A.V. [Co-authored works listed under Braines, S.N.]

Nehamas, Alexander. [See work listed under Plato]

Nell, E., "No Proposition Can Describe Itself," ANALYSIS, 26 (1966) 147-48.

Nell, E., "Semantics and Self-Description," ANALYSIS, 18 (1967) 32.

Nelson. E., Review of Ushenko's THE PROBLEMS OF LOGIC (q.v.), JOURNAL OF SYMBOLIC LOGIC, 6 (1941) 166-68.

Nelson, John O. [See work listed under Descartes] 
Neumann, Erich. THE ORIGINS AND HISTORY OF CONSCIOUSNESS. Princeton University Press, 1954. Chapter

A.I: The Creation Myth: The Uroboros. (On circle as symbol of creation, development, perfection.)

[Neumann, J. Von], See: Harrison, C.

Newcomb, Theodore M. [Co-authored work listed under Chowdhry, K.]

Newman, James R. [See work listed under Gödel]

Nicolis, G. SELF ORGANIZATION IN NONEQUILIBRIUM SYSTEMS: FROM DISRUPTIVE STRUCTURES TO ORDER THROUGH FLUCTUATIONS. N.Y.: John Wiley and Sons, 1977.

Nicolson, Marjorie Hope. THE BREAKING OF THE CIRCLE. Northwestern University Press, 1950.

Niemi, Gunnar Wayne. MODALITY AND SELF-REFERENCE. Ph.D. Dissertation, University of Michigan, 1970.

[Nietzsche], Altizer, Thomas J.J., "Eternal Recurrence and Kingdom of God," in David B. Allison (ed.), THE NEW NIETZSCHE: CONTEMPORARY STYLES OF INTERPRETATION, pp. 232-46. Dell Pub. Co., 1977.

[Nietzsche], Baker, Thomas A. THE ONTOLOGICAL CONNECTION BETWEEN NIETZSCHE'S WILL TO POWER AND ETERNAL RETURN. Ph.D. Dissertation, Marquette University, 1983.

[Nietzsche], Brush, Stephen G., "Nietzsche's Recurrence Revisited: The French Connection," JOURNAL OF THE HISTORY OF PHILOSOPHY, 19, 2 (April 1981) 235-38.

[Nietzsche], Clegg, Jerry S., "Nietzsche and the Ascent of Man in a Cyclical Cosmos," JOURNAL OF THE HISTORY OF PHILOSOPHY, 19, 1 (Jan 1981) 81-93.

[Nietzsche], Danto, Arthur, "The Eternal Recurrence," in Robert Solomon (ed.), NIETZSCHE: A COLLECTION OF CRITICAL ESSAYS, pp. 316-21. Anchor Books, 1973.

[Nietzsche], Hatab, Lawrence J. NIETZSCHE AND ETERNAL RECURRENCE: THE REDEMPTION OF TIME AND BECOMING. University Press of America, 1978.

[Nietzsche], Grimm, Ruediger Hermann, "Circularity and Self-Reference in Nietzsche," METAPHILOSOPHY, 10 (1979) 284-305.

[Nietzsche], Kain, Philip J., "Nietzsche, Skepticism, and Eternal Recurrence," Paper delivered orally at convention of the American Philosophical Association, Baltimore, December 28, 1982. 
[Nietzsche], Klossowski, Pierre, "Nietzsche's Experience of the Eternal Return," in David B. Allison (ed.), THE NEW NIETZSCHE:

CONTEMPORARY STYLES OF INTERPRETATION, pp. 107-20. Dell Pub. Co., 1977.

[Nietzsche], Krueger, Joe, "Nietzschean Recurrence as a Cosmological Hypothesis," JOURNAL OF THE HISTORY OF PHILOSOPHY, 16 (1978) 435-44.

[Nietzsche], Löwith, Karl, "Nietzsche's Revival of the Doctrine of

Eternal Recurrence," Appendix II of his MEANING IN

HISTORY, pp. 214-22. University of Chicago Press, 1949.

[Nietzsche], Sandra. NIETZSCHE'S DOCTRINE OF ETERNAL RECURRENCE: THE MOST SCIENTIFIC OF ALL POSSIBLE HYPOTHESES. Ph.D. Dissertation, University of Missouri, Columbia, 1984.

[Nietzsche], Small, Robin, "Nietzsche and a Platonist Tradition of the Cosmos: Center Everywhere and Circumference Nowhere," JOURNAL OF THE HISTORY OF IDEAS, 44, 1 (January-March 1983) 89-104.

[Nietzsche], Soll, Ivan, "Reflections on Recurrence: A Reexamination of Nietzsche's Doctrine, die Ewige Wiederkehr des Gleichen," in Robert Solomon (ed.), NIETZSCHE: A COLLECTION OF

CRITICAL ESSAYS, pp. 322-42. Anchor Books, 1973.

[Nietzsche], Stambaugh, Joan. Nietzsche'S THOUGHT OF ETERNAL RETURN. Johns Hopkins University Press, 1972.

[Nietzsche], Williams, Robert. RECURRENCE, PARODY, AND

POLITICS IN THE PHILOSOPHY OF FRIEDRICH

NIETZSCHE. Ph.D. Dissertation, Yale University, 1982.

[Nietzsche], Zuboff, Arnold, "Nietzsche and Eternal Recurrence," in Robert Solomon (ed.), NIETZSCHE: A COLLECTION OF CRITICAL ESSAYS, pp. 343-57. Anchor Books, 1973.

[Nietzsche, Friedrich], See: Delevsky, J.; Heidegger, M.; Jaki, S.C. (chapter 13).

Nigel, Howard. PARADOXES OF RATIONALITY: THEORY OF METAGAMES AND POLITICAL BEHAVIOR. Massachusetts Institute of Technology Press, 1971.

Nissen, L. [See work listed under Nagel]

Noelle-Neumann, Elisabeth. THE SPIRAL OF SILENCE: PUBLIC OPINION --OUR SOCIAL SKIN. University of Chicago Press, 1984.

Norman, B.R. [See work listed under Heidegger.]

Norman, J. [Co-edited work listed under Priest, G.]

Northrop, E.P. RIDDLES IN MATHEMATICS: A BOOK OF PARADOXES. Van Norstrand Reihold Co., 1944. Reprinted, 
R.E. Krieger Pub. Co., 1975. (See review by Nagel, E.)

Nozick, Robert. PHILOSOPHICAL EXPLANATIONS. Harvard University Press, 1981. Chapter 1, Section II: Reflexivity, pp. 71-114.

Oakes, Robert A., "Religious Experience, Self-Authentication, and Modality De Re: A Prolegomenon," AMERICAN PHILOSOPHICAL QUARTERLY, 16, 3 (July 1979). (See review by Levine, $M$.)

O'Brien, James F., "Teilhard and Aristotle: What is Radial and What is Tangential?" NEW SCHOLASTICISM, 49 (1975) 486-91.

O'Carroll, M.J., "Improper Self-Reference in Classical Logic and the Predication Paradox," LOGIQUE ET ANALYSE, 10 (June 1967) 167-72.

O'Carroll, M.J., "A Three-valued, Non-Levelled Logic Consistent For All Self-Reference," LOGIQUE ET ANALYSE, 10 (June 1967) 173-78.

[Ockham, William of], See: Spade, P.V.

O'Connor, John, "On Eliminating Self-Reference," ANALYSIS, 28 (1968) 131-32. (See review by Schlesinger, G.)

O'Connor, D.J., "Pragmatic Paradoxes," MIND, 57 (1948) 358-59. (See review by Cohen, L.J.)

O'Connor, D.J., "Pragmatic Paradoxes and Fugitive Propositions," MIND, 60 (1951) 536-38.

Odegard, Douglas, "Classifying the Class-Membership Relation," LOGIQUE ET ANALYSE, 12 (1969) 221-24.

Odegard, Douglas, "The Irreflexivity of Knowledge," in Steven J. Bartlett and Peter Suber (eds.), SELF-REFERENCE (q.v.).

Odegard, Douglas, "Knowledge and Reflexivity," DIALOGUE, 15 (April 1976) 226-40.

Odegard, Douglas, "Parasitical Reference and Paradox," AMERICAN PHILSOPHICAL QUARTERLY, 13, 4 (Oct. 1976) 295-301. (Solutions to the liar, heterological, and Russell's paradox.)

Odegard, Douglas, "Truth," Chapter Four of his KNOWLEDGE AND SCEPTICISM, pp. 40-55. Rowman and Littlefield, 1982. (On paradox and its avoidance.)

Odegard, Douglas. [See work listed under Descartes.]

Olbrechts-Tyteca, L. [Co-authored work listed under Perelman, C.] Oldenquist, Andrew, "Self-Prediction," in Paul Edwards (ed.), ENCYCLOPEDIA OF PHILOSOPHY, 7:344-48. Macmillan, 1967. 
[Oliver, Thomas], See: Thomas, I.

Olson, Paul R. [See work listed under Jimenez]

Onians, Richard Broxton. THE ORIGINS OF EUROPEAN THOUGHT. Cambridge University Press, 1951. (Much on theme of circle in re time, fate, telos.)

Orey, S. Review of Bowden's "Heterologicality" (q.v.), Landsberg's "On Heterological Paradoxes" (q.v.), Mackie and Smart's "A Variant of the ..." (q.v.), Killalea's "Primeness and Heterologicality" (q.v.), Lawrence's "Heterology and Hierarchy" (q.v.), MacDonald (ed.), PHILOSOPHY AND ANALYSIS (q.v.), Ryle's "Heterologicality" (in MacDonald), JOURNAL OF SYMBOLIC LOGIC, 20 (1955) 291-93.

Orgass, R.J. [Co-authored works listed under Fitch, F.B.]

Orr, William F., "A Minimal Self-Predicative Bibliography," AMERICAN MATHEMATICAL MONTHLY, 86 (1979) 79.

[Paine, Thomas], See: Brown, T.M.

Palmer, Humphrey, "Do Circular Arguments Beg the Question?" PHILOSOPHY, 56, 215 (July 1981) 387-94.

Pap, Arthur, "The Linguistic Hierarchy and the Vicious Circle Principle," PHILOSOPHICAL STUDIES, 5 (1954) 49-53. (See review by Bausch, A.)

Parker, DeWitt, H., "Reflexive Relations," PHILOSOPHICAL REVIEW, 42 (1933) 303-311, and 43 (1934) 295-300.

[Parmenides], Jameson, G., "'Well-Rounded Truth' And Circular Thought in Parmenides," PHRONESIS, 3 (1958) 15-30.

[Parmenides], See: Ballew, L.

Parsons, C., "The Impredicativity of Induction," in Leigh Cauman et al. (eds.), HOW MANY QUESTIONS? ESSAYS IN HONOR OF SIDNEY MORGENBESSER, Hackett Pub. Co., 1983.

Parsons, C. [Co-authored work listed under Kohl, H.R.]

[Pascal, Blaise], See: Borges, J.L.

Pask, G., and G. Von Foerster, "A Predictive Model for Self-Organizing Systems," CYBERNETICA, 3, 4 (1960) 258-300; 4, 1 (1961) 20-55.

Passmore, John. PHILOSOPHICAL REASONING. Duckworth, 1961.

Pastin, Mark, "Modest Foundationalism and Self-Warrant," AMERICAN PHILOSOPHICAL QUARTERLY, Monograph \#4, pp. 141-49. Reprinted in G.S. Pappas and M. Swain (eds.), ESSAYS ON KNOWLEDGE AND JUSTIFICATION, Cornell 
University Press, 1978, pp. 279-88.

[Paul, St.], See: Anderson, A.R.

Paulos, John Allen, "Self-Reference and Paradox," Section of his

MATHEMATICS AND HUMOR, pp. 41-55. University of

Chicago Press, 1980.

Peck, "Federal Tax Liens - Their Removal or Foreclosure, Privity Thereof, and the Problem of Circuity of Priorities," NEBRASKA LAW REVIEW, 38 (1959) 163, 170.

Pei, Mario, "Self-Designation," Chapter 10 of his THE STORY OF LANGUAGE, pp. 394-96. J.B. Lippencott Co., revised edition, 1965.

[Peirce, Charles Sanders], See: Rivetti Barbo, F.; Thompson, M.H., Jr.; Levi, I.

Penrose, L.S., "Automatic Mechanical Self-Reproduction," in NEW BIOLOGY, pp. 92-117. Penguin, 1959.

Penrose, L.S., "Self-Reproducing Machines," SCIENTIFIC AMERICAN, 200, 6 (1959) 105-112, 114, 202.

Pereleman, Chaim, and L. Olbrechts-Tyteca. THE NEW RHETORIC:

A TREATISE ON ARGUMENTATION. University of Notre

Dame Press, 1969. Section 28: Argumentation ad Hominem and Begging the Question.

Peter, Rozsa. RECURSIVE FUNCTIONS. Academic Press, 1967.

Peters, Michael. [Co-authored work listed under Marshall, J.]

Peterson, Sandra. "A Reasonable Self-Predication Premise for the

Third Man Argument," THE PHILOSOPHICAL REVIEW, 82 (1973) 451-70.

Phillips, O. Hood, "Self-Limitation by the United Kingdom Parliament," HASTINGS CONSTITUTIONAL LAW QUARTERLY, 2 (1975) 443-78.

Pinto, W.L. [See work listed under Plato]

[Plato], Apolloni, David. PLATO AND THE SELF-PREDICATION ASSUMPTION. Ph.D. Dissertation, University of Minnesota, 1980.

[Plato], Clegg, Jerry S., "Self-Predication and Linguistic Reference in Plato's Theory of Forms," PHRONESIS, 18 (1973) 26-73.

[Plato], Driscoll, John A., "Self-Participation and the Non-Identity Assumption in Plato's 'Sophist'," Paper delivered orally at Convention of the American Philosophic Association, Pacific Division, San Francisco, March 28, 1980.

[Plato], Duff-Forbes, D.R., "The Regress Arguments in the Republic," MIND, 87, 307 (July 1968) 406-10.

[Plato], Dyson, M., "Some Problems Concerning Knowledge In Plato's 'Charmides'," PHRONESIS, 19 (1974) 102-111. 
[Plato], Gould, Carol Steinberg. EPONYMY AND SELF PREDICATION IN PLATO'S MIDDLE THEORY OF FORMS. Ph.D. Dissertation, State University of New York, Buffalo, 1984.

[Plato], Haynes, Richard Pierce. PLATO'S THEORY OF FORMS AND THE SELF-PREDICATION ASSUMPTION. Ph.D. Dissertation, University of Illinois, Urbana-Champagne, 1962.

[Plato], Lee, Edward N., "Reason and Rotation: Circular Movement as the Model of Mind (nous) in the Later Plato," in W.H. Werkmeister (ed.), FACETS OF PLATO'S PHILOSOPHY. Supplementary Volume II of PHRONESIS: A JOURNAL FOR ANCIENT PHILOSOPHY. Assen: Van Gorcum, 1976.

[Plato], Mann, William E., "The Third Man--The Man Who Never Was," AMERICAN PHILSOPHICAL QUARTERLY, 16, 3 (July 1979) 167-76.

[Plato], Nehamas, Alexander, "Self-Predication and Plato's Theory of Forms," AMERICAN PHILOSOPHICAL QUARTERLY, 16, 2 (April 1979) 93-103.

[Plato], Pinto, W.L. SELF-PREDICATION OF THE FORMS IN PLATO'S PARMENIDIES AND SOPHIST. Ph.D. Dissertation, University of Pennsylvania, 1976.

[Plato], Savan, D. "Self-Predication in PROTAGORAS 330-331," PHRONESIS, 9 (1984) 130-35.

[Plato], Smith, John L. PLATO AND THE PARADOX OF FALSE STATEMENTS: A STUDY OF THE EUTHYDEMUS AND THE SOPHIST. Ph.D. Dissertation, University of Virginia, 1975.

[Plato], Spitzer, Adele, "The Self-Reference of the GORGIAS," PHILOSOPHY AND RHETORIC, 8 (Winter 1975) 1-22.

[Plato], Thomas, William J., "Platonism and the Skolem Paradox," ANALYSIS, 28 (June 1968) 193-96.

[Plato], Vlastos, Gregory, "On a Proposed Redefinition of 'Self-Predication' in Plato," PHRONESIS, 26, 1 (1981) 76-78.

[Plato], Yartz, Frank J., "Infinite Regress and the Sense World in Plato," SOUTHWESTERN JOURNAL OF PHILOSOPHY, 6 (1975) 17-28.

[Plato], See: Ballew, L.; Burnyeat, M.F.; Teloh, H.

Plommer, H. [See work listed under Vitruvius]

[Plotinus], Fiedler, John, "Plotinus and Self-Predication," in R. Baine Harris (ed.), THE STRUCTURE OF BEING: A NEOPLATONIC APPROACH. State University of New York Press, 1982.

[Polanyi, Michael], See: Moleski, M.X. 
Pollock, John L., "The Liar Strikes Back," JOURNAL OF PHILOSOPHY, 74, 10 (Ott 1977).

Popper, Karl, "Is Determinism Self-Refuting?" MIND, 92, 365 (January 1983) 103-04.

Popper, Karl, "Self-Reference and Meaning in Ordinary Language," MIND, 63 (195.4) 162-69. Reprinted in his CONJECTURES AND REFUTATIONS: THE GROWTH OF SCIENTIFIC KNOWLEDGE. Basic Books, 1962, pp. 304-11. (See reviews by Thompson, J.F., and Prior, A.N.)

Portmess, Lisa. TIME AND PARADOX. Ph.D. Dissertation, Queens University, 1979.

Post, John F., "The Possible Liar," NOUS, 4, 4 (Nov. 1970) 405-09. Post, John F., "Presupposition, Bivalence, and the Possible Liar," PHILOSOPHIA: PHILOSOPHICAL QUARTERLY OF ISRAEL, 8, 4, (Dec. 1978).

Post, John F., "Shades of the Liar," JOURNAL OF PHILOSOPHIC LOGIC, 2 (July 1973) 370-85.

Potter, Richard C. INTENTIONALITY AND THE PARADOX OF THE LIAR. Ph.D. Dissertation, Brown University, 1980.

Poulet, Georges. THE MET AMORPHOSES OF THE CIRCLE. Johns Hopkins University Press, 1966.

Poundstone, William. THE RECURSIVE UNIVERSE: COSMIC COMPLEXITY AND THE LIMITS OF SCIENTIFIC KNOWLEDGE. William Morrow and Co., 1985.

Prado, C.G., "Reflexive Awarness," THE NEW SCHOLASTICISM, 52, 3 (Summer 1978) 428-33.

Prado, C.G., "Reflexive Consciousness," DIALOGUE, 17 (1978) 134-37.

Price, H.H., "Self-Verifying Beliefs," Lecture 6, Series II, of his Gifford Lectures, 1959-60. Published in his BELIEF, pp. 349-75. Humanities Press, 1969.

Priest, Graham, "An Anti-Realist Account of Mathematical Truth," SYNTHESE, 57 (1983) 49-65.

Priest, Graham, "Classical Logic Aufgehoben," in Priest, Routley, and Norman (eds.), PARACONSISTENT LOGIC, q.v.

Priest, Graham, "Contradiction, Belief and Rationality," PROCEEDINGS OF THE ARISTOTELIAN SOCIETY, 86, 99-116.

Priest, Graham, "The Conventionalist Philosophy of Mathematics," PROCEEDINGS OF THE BERTRAND MEMORIAL LOGIC CONVERENCE, ed. J. Bell et al., Leeds, 1973, pp. 115-32.

Priest, Graham, "Hypercontradictions," LOGIQUE ET ANALYSE, 107 (1984) 237-43. 
Priest, Graham, and R. Routley, "Introduction to Paraconsistent Logic," STUDIA LOGICA, 44 (1983) 3-16.

Priest, Graham, and R. Routley, "Lessons from Pseudo-Scotus," PHILOSOPHICAL STUDIES, 42 (1982) 189-99.

Priest, Graham, "The Logical Paradoxes and the Law of Excluded Middle," PHILOSOPHICAL QUARTERLY, 33 (1983) 160-65. (See reply by Brady, R.T.)

Priest, Graham, "The Logic of Paradox," JOURNAL OF PHILOSOPHIC LOGIC, 8 (May 1979) 219-41.

Priest, Graham, "The Logic of Paradox Revisisted," JOURNAL OF PHILOSOPHICAL LOGIC, 12 (1984) 153-179.

Priest, Graham, "The Logical Paradoxes: A Unified Account," paper delivered orally at a conference of the Australasian Association of Logic, Melbourne University, 1977.

Priest, Graham, "The Logical Paradoxes," PHILOSOPHICAL QUARTERLY, 33, (April 1983) 160-65.

Priest, Graham, and R. Routley. ON PARACONSISTENCY. Research Report \#13, Research School of Social Sciences, Australian National University, 1983. Reprinted as introductory chapters of Priest, Routley, and Norman (eds.), PARACONSISTENT LOGIC, q.v.

Priest, Graham, R. Routley, and J. Norman (eds.). PARACONSISTENT LOGIC. Philosophia Verlag, 1986.

Priest, Graham, "Principia Mathematica and the Vicious Circle Principle," paper delivered orally at a conference of the British Society for the Philosophy of Science, Warwick University, 1976.

Priest, Graham, "Reductio ad Absurdum et Modus Tollendo Ponens," in Priest, Routley, and Norman (eds.), PARACONSISTENT LOGIC, q.v.

Priest, Graham, and J. Crosthwaite, "Relevance, Truth and Meaning," in R. Routley and J. Norman (eds.), DIRECTIONS OF RELEVANT LOGIC, Martinus Nijhoff, forthcoming.

Priest, Graham, "Semantic Closure," STUDIA LOGICA, 43 (1984) 117-29.

Priest, Graham, "Sense, Entailment and Modus Ponens," JOURNAL OF PHILOSOPHICAL LOGIC, 9 (1980) 415-35.

Priest, Graham, and C. Mortensen, "The Truth Teller Paradox," LOGIQUE ET ANALYSE, 95-96 (1981) 381-88.

Priest, Graham, "Unstable Solutions to the Liar Paradox," in Steven J. Bartlett and Peter Suber (eds.), SELF-REFERENCE (q.v.).

Prior, A.N., "The Cogito of Descartes and the Concept of Self-Confirmation," PAPERS IN LOGIC AND ETHICS, pp. 
165-75, P.T. Geach and A.J.P. Kenny (eds.) London: Duckworth, 1976.

Prior, A.N., "Epimenides the Cretan," JOURNAL OF SYMBOLIC LOGIC, 23 (1958) 261-66. (Sec review by Kanger, S.)

Prior, A.N., "On a Family of Paradoxes," NOTRE DAME JOURNAL OF FORMIAL LOGIC, 2 (1961) 16-32.

Prior, A.N., "Symmetry, Transitivity, and Reflexivity," JOURNAL OF THIE PIHLOSOPIICAL ASSOCIATION, 7 (1960) 67-70.

Prior, A.N. Review of Fitch's "Self-Referential Relations," (q.v.), JOURNAL OF SYMBOLIC LOGIC, 24 (1959) 240.

Prior, A.N. Review of Popper's "Self-Reference and Meaning in Ordinary Language," (q.v.), JOURNAL OF SYMBOLIC LOGIC, 24, (1959) 240.

Prior, A.N., "Some Problems of Self-Reference in John Burdian," PROCEEDINGS OF THE BRITISH ACADEMY, 48 (1962) 115-26.

[Protagoras], Sec: Aqvist, L.; Bryant, J.; Bumyeat, M.F.; Lenzen, W.;

Goossens, WV.K.; Miciland, J.W.

[Pseudo-Scotus], Sec: Priest, G. and Routley, R.

Pugmire, David, "'Strong' Self-Deception," INQUIRY, 12 (Fall 1969) 339-361.

Putnam, Hilary. [Co-authored work listed under Smullyan, R.]

$$
\cdot \mathrm{Q} \cdot
$$

Quine, W.V.O. , "On a So-Called Paradox," MIND, 62 (1955) 65-67.

Quine, W.V.O., "Paradox," SCIENTIFIC AMERICAN, 206 (1962)

84-96. Reprinted in his THE WAYS OF PARADOX, (q.v.), pp. $1-20$.

Quine, W.V.O. Review of Menger's "The New Logic," (q.v.), JOURNAL OF SYMIBOLIC LOGIC, 3 (1938) 48.

Quine, W.V.O. THE IVAYS OF PARADOX AND OTHER ESSAYS. Random House, 1966.

[Quine], Roth, Paul A., "Paradox and Indeterminacy," JOURNAL OF PHILOSOPHY, 75, 7 (July 1978) 345-67.

[Quine, W.V.O.], Sce: Swiggart, P.

Quiney, H.R., "A Non-Hicrarchical Mathematical Logic," AUSTRALASIAN JOURNAL OF PHILOSOPHY, 10 (1932) 216-21.

Radnitzky, G., "Toward a Theory of Research Which is Neither 
Logical Reconstruction nor Psychology or Sociology of Science," TEORIE E METODA, 3 (1973) 197-264. (On a reflexive method.)

[Ramsey, Frank], See: Hart, W.D.

Ramsey, I.T., "The Paradox of Omnipotence," MIND, 65 (1956) 263-66.

Rankin, K.W., "Referential Identifiers," AMERICAN PHILOSOPHICAL QUARTERLY, 1 (July 1964) 233-43.

Rayfield, David. [See work listed under Miller, A.R.]

Raz, Joseph. [See work listed under Ross, A.]

Reach, K., "The Name Relation and the Logical Antinomies," JOURNAL OF SYMBOLIC LOGIC, 3 (1938) 97-111. (See review by Henle, P.)

Read, Stephen, "Self-Reference and Validity," SYNTHESIS, 42 (October 1979) 265-74.

Rechtin, Lisbeth, and William Todd, "Propositional Attitudes and Self-Reference," PHILOSOPHIA, 4 (April-July 1974) 271-95.

Rees, W.J., "The Theory of Sovereignty Restated," MIND, 59 (Oct. 1950) 495-521. (Much on parliamentary omnipotence.)

Reeves, Sandra. [See work listed under Nietzsche.]

Regnell, Hans, "A New Approach to the Liar and Some Other Paradoxes," DANISH YEARBOOK OF PHILOSOPHY, 5 (1968) 7-30.

Regnell, Hans, "On Reflexivity," DANISH YEARBOOK OF PHILOSOPHY, 1 (1964) 112-19.

Reichenbach, Bruce R. [See work listed under Mavrodes]

Reiss, T.T. [See work listed under Jodelle]

Rescher, Nicholas, "The 'No Criterion' Argument: "The Wheel'," Chapter 1 of his SCEPTICISM: A CRITICAL REAPPRAISAL, pp. 11-15. Rowman and Littlefield, 1980. (Skeptical diallelus as an alternative to infinite regress.)

Rescher, Nicholas, N., "A Note on Self-Referential Statements," NOTRE DAME JOURNAL OF FORMAL LOGIC, 5 (1964) 218-20.

Rescher, Nicholas, "Semantic Paradoxes and the Propositional Analysis of Indirect Discourse," PHILOSOPHY OF SCIENCE, 28 (1961) 437-40.

Resnick, M.D., "Professor Goddard and the Simple Theory of Types," MIND, 77 (1968) 565-68.

[Richard, Thomas J.], See: Jackson, Frank

Richards, Thomas J., "Self-Referential Paradoxes," MIND, 76 (July 1967) 387-403.

Richardson, Jane Shelby. [Co-authored work listed under Scriven] 
Richman, R.J., "On the Self-Reference of Meaning Theory," PHILOSOPHICAL STUDIES, 4 (1953) 69-72.

Richter, Jean Paul. HORN OF OBERON: JEAN PAUL RICHTER'S SCHOOL FOR AESTHETICS. Wayne State University Press, 1973. Section 46: Circular Wit.

Riguet, J. [Co-authored work listed under Ashby, W.R.]

Rinaldi, Fiori, "Dilemmas and Circles in the Law," ARCHIV FÜR RECHTS-UND SOZIALPHILOSOPHIE, 51 (1965) 319-335.

Roberts, Joy H. [See work listed under McTaggart, J.E.M.]

Roberts, Louise Nisbet, "Every Proposition Is False -A Medieval

Paradox," TULANE STUDIES IN PHILOSOPHY, 2 (1953) 95-102.

Robinson, Richard, "Begging the Question," ANALYSIS, 31 (March 1971) 113-17.

Rockmore, Tom. [See works listed under Hegel.]

Romanos, George D., "Reflexive Predictions," PHILOSOPHY OF SCIENCE, 40 (1973) 97-109.

Rorty, Amelie Oksenberg, "Reflexive Attitudes," Paper delivered orally at Convention of American Philosophical Association, N.Y., Dec. 29, 1979.

Rorty, Amelie Oksenberg. SELF-REFERENCE AND THE THEORY OF ERROR: DESCARTES, HUME, AND BRADLEY ON PHILOSOPHIC METHOD, Ph.D. Dissertation, Yale University, 1980.

Rorty, Richard, "The Limits of Reductionism," in I. Lieb (ed.), EXPERIENCE, EXISTENCE AND THE GOOD, pp. 100-116. Southern Illinois University Press, 1961. (Appeal to self-referential consistency.)

Rorty, Richard, "Transcendental Arguments, Self-Reference, and Pragmatism," in Rolf-Peter Horstmann (ed.), TRANSCENDENTAL ARGUMENTS AND SCIENCE, pp. 77-103. Reidel Pub. Co., 1979.

Rosenkrantz, Gary, and Joshua Hoffman, "What an Omnipotent Agent Can Do," INTERNATIONAL JOURNAL FOR PHILOSOPHY OF RELIGION, 11 (1980) 1-19.

Ross, Alf. ON LAW AND JUSTICE. London: Stevens, 1958. (Section 16 on the paradox of self-amendment.)

Ross, Alf, "On Self-Reference and a Puzzle of Constitutional Law," MIND, 78 (1969) 1-24. (On parliamentary omnipotence and self-amendment.)

[Ross, Alf], Hoerster, Norbert, "On Alf Ross's Alleged Puzzle in Constitutional Law," MIND, 81 (1972) 422-26.

[Ross, Alf], Raz, Joseph, "Professor Ross and Some Legal Puzzles," 
MIND, 81 (1972) 415-21.

Rosser, J. [Co-authored work listed under Kleene, S.]

Rotenstreich, Nathan, "Self-Ascription and Objectivity," PHILOSOPHIA, 10, 3-4, pp. 189-98. (See reply by Strawson, P.F. at end of issue.)

Roth, G., and H. Schegler (eds.). SELF-ORGANIZING SYSTEMS. Campus, 1981.

Roth, Paul A. [See work listed under Quine]

Rothschild, K.W., "Cobweb Cycles and Partially Correct Forecasting," JOURNAL OF POLITICAL ECONOMY, 72 (June 1964) $300-05$.

Routley, R. [Co-authored work listed under Priest, G.]

Routley, R. [Co-edited work listed under Priest, G.]

Rowe, William L. [See work listed under Anselm]

Royce, Josiah, "Theory of the Sources and Consequences of Any Recurrent Operation of Thought. The Nature of

Self-Representative Systems," Section III of the Supplementary

Essay of his THE WORLD AND THE INDIVIDUAL: FIRST

SERIES: THE FOUR HISORICAL CONCEPTIONS OF

BEING, pp. 501-54. Dover Publications, 1959. (Original,

Macmillan, 1899.)

[Royce], Skinner, John E. THE LOGOCENTRIC PREDICAMENT:

AN ESSAY ON THE PROBLEM OF ERROR IN THE

PHILOSOPHY OF JOSIAH ROYCE. University of

Pennsylvania Press, 1965.

Rozeboom, W.W., "Is Epimenides Still Lying?" ANALYSIS, 18 (1957-58) 105-13. (See review by Bennet, J.)

Russell, Bertrand, "Mathematical Logic as Based on the Theory of

Types," AMERICAN JOURNAL OF MATHEMATICS, 30 (1908) 222-62.

Russell, Bertrand, "On 'Insolubilia' and Their Logical Solution by

Symbolic Logic," in Douglas P. Lackey (ed.), ESSAYS IN

ANALYSIS [all by Russell], pp. 190-214. Allen and Unwin, 1973.

Russell, Bertrand. [Co-authored work listed under Whitehead, A.N.]

[Russell], See: Harrison, Craig; Hart, W.D.;Moulder, J.

Rutter, Michael, and Nicole Madge. CYCLES OF DISADVANTAGE:

A REVIEW OF RESEARCH. London: Heinemann, 1976.

Ryle, Gilbert, "Heterologicality," ANALYSIS, 11 (1951) 61-69. Reprinted in M. MacDonald, PHILOSOPHY AND ANLYSIS (q.v.). (See reviews by Geach, P.T. and Orey, S.) 
Sadovski, V.N. [Co-authored work listed under Blauberg, I.V.]

Safir, Orin. [See work listed under Gödel]

Sagarin, Edward, and R.J. Kelly, "The Brewster Effect: Political

Trials and the Self-Defeating Prophecy," Paper presented at a conference of the American Sociological Association, New Orleans, 1972.

Saito, Setsuo, "Circular Definitions and Analyticity," INQUIRY, 5 (1962) 158-62.

Sandywell, Barry, et al. PROBLEMS OF REFLEXIVITY AND DIALECTICS IN SOCIOLOGICAL INQUIRY: LANGUAGE THEORIZING DIFFERENCE. Routledge and Kegan Paul, 1975.

Sanford, David, "Begging the Question," ANALYSIS, 32 (1972) 197-99. (See review by Barker.)

Sanford, David, "The Fallacy of Begging the Question: A Reply to Barker," DIALOGUE, 16 (1977) 485-98.

Saridis, George N. SELF-ORGANIZING CONTROL OF STOCHASTIC SYSTEMS. N.Y.: M. Dekker, 1977.

Sartre, Jean-Paul, "The Circularity of Dialectical Investigation," Chapter 7, Section 2 of his CRITIQUE OF DIALECTICAL REASON. Verso/NLB, 1976.

Savage, L. Wade, "The Paradox of the Stone," PHILOSOPHICAL REVIEW, 76 (1967) 74-79. (On God's omnipotence.)

Savan, D. [See work listed under Plato]

Schick, Frederic, "Consistency," PHILOSOPHICAL REVIEW, 75 (October 1966) 467-95.

[Schlegel, Friedrich], See: Higonnet, M.R.

[Schleiermacher, Friedrich Daniel], See: Maraldo, J.C.

Schlesinger, G., "Eliminating Self-Reference Once More," ANALYSIS, 29 (1969) 135-39. (A reply to O'Connor's reply.)

Schlesinger, G., "Elimination of Self-Reference," ANALYSIS, 27 (1967) 206-08. (See O'Conner, J.)

Schlesinger, G., "Omnipotence and Evil: An Incoherent Problem," SOPHIA, 4 (1965) 21-24.

Schlueter, June. METAFICTIONAL CHARACTERS IN MODERN DRAMA. Columbia University Press, 1979.

Schmidt, Paul F., "Self-Referential Justification," PHILOSOPHICAL STUDIES, 8 (1957) 49-54.

Schoenberg, Judith, "Belief and Intention in the Epimenides," PHILOSOPHY AND PHENOMENOLOGICAL RESEARCH, 30 (December 1969) 270-78.

Scholes, Robert, "Imagination Dead Imagine: Reflections on 
Self-Reflexive Fiction," in his FABULATION AND

METAFICTION, pp 210-18. University of Illinois Press, 1979.

Schuster, Peter. [Co-authored work listed under Eigen, M.]

Schwartz, Eugene M. "Self-Reference -Paradox . . . or Bluff?,"

published in form of xeroxed typescript sold for $\$ 1.00$, by

Eugene M. Schwartz Association, 1160 Park Avenue, PH-W,

N.Y., N.Y. 10028.

Schwegler, H. [Co-edited work listed under Roth, G.]

Scriven, Michael, "An Essential Unpredictability in Human Behavior," in B.J. Wolman and E. Nagel (eds.), SCIENTIFIC PSYCHOLOGY: PRINCIPLES AND APPROACHES, pp. 411-25. Basic Books, 1964.

[Scriven, Michael], Lewis, David K. and Jane Shelby Richardson, "Scriven on Unpredictability," PHILOSOPHICAL STUDIES, 17 (Oct. 1966) 69-74.

Seebohm, Thomas, "Reflexion, Interpretation, Dialectics," GRADUATE FACULTY PHILOSOPHY JOURNAL, vol. 7, No. 1.

Sell, Jesse Jeremiah. A STUDY OF THE SELF-PREDICATION STATEMENTS ATTRIBUTED TO "JESUS CHRIST" IN THE NAGA-HAMMADI COPTIC "GNOSTIC" CORPUS. Ph.D. Dissertation, Duke University, 1976.

Sextus Empiricus. AGAINST THE LOGICIANS. Loeb Classical Library, Harvard University Press, 1961.

Shafer, Ingrid Hedwig. THE INFINITE CIRCLE: THE CHILIASTIC SOUL IN HEGEL, JUNG, AND HESSE, WITH PARTICULAR EMPHASIS ON HEGELIAN AND JUNGIAN ELEMENTS IN HESSE'S GLASPERLENSPIEL. Ph.D. Dissertation, University of Oklahoma, 1984.

[Shakespeare], See: Calderwood, J.L.

Shaw-Kwei, Moh, "Logical Paradoxes for Many-Valued Systems,"

JOURNAL OF SYMBOLIC LOGIC, 19 (1954) 37-40.

Shepard, Roger N., "Circularity in Judgments of Relative Pitch," JOURNAL OF THE ACOUSTICAL SOCIETY OF AMERICA, 36, 12 (Dec. 1964) 2346-53.

Shepheard, Miles. [Co-authored work listed under Marshall, J.]

Sherwood, Rae. THE PSYCHODYNAMICS OF RACE: VICIOUS AND BENIGN SPIRALS. Humanities Press, 1980.

Shiner, Roger A., "Self-Reference and the Third Man Argument," JOURNAL OF THE HISTORY OF PHILOSOPHY, 8 (1970) 371-86.

Shir, Jay, "Symbolism and Autosymbolism," JOURNAL OF AESTHETICS AND ART CRITICISM, 37, 1 (Fall 1978) 
81-89.

Shoch, John F. and Jon A. Hupp, "Notes on the 'Worm' Programs--Some Early Experience With A Distributed Computation," COMMUNICATIONS OF THE ACM.

Shoemaker, Sidney, "Self-Reference and Self-Awareness," in J.G. Gill (ed.), PHILOSOPHY TODAY No. 3, pp. 32-90. Macmillan, 1970.

Shoenfield, J. R., Review of Smullyan's "Languages in which Self-Reference is Possible," (q.v.), JOURNAL OF SYMBOLIC LOGIC, 24 (1959) 228.

Shovokhova, E.B., "On the Reflexive Nature of Psychics," PAKISTAN PHILOSOPHICAL CONGRESS, 10 (1963) 306-11.

Shreider, I.A. [Co-authored work listed under Braines, S.N.]

Sibajiban, "Can Doubt Be Doubted?," JOURNAL OF SYMBOLIC LOGIC, 27 (March 1962) 1114.

Sibajiban, "Mr. Eric Toms on the Liar Paradox," MIND, 74 (1965) 421-23. (See review by Bennet, J.)

Siegler, F.A., "On Lying to Oneself," JOURNAL OF PHILOSOPHY, 59 (August 1962) 469-74.

Sigler, J.A., "The Cybernetics Model of the Judicial System," TEMPLE LAW QUARTERLY, 41 (1968) 398.

Simon, Herbert, "Bandwagon ond Underdog Effects and the Possibility of Election Predictions," PUBLIC OPINION QUARTERLY, (Fall 1954) 245-53.

Simos, Miriam (Starhawk). THE SPIRAL DANCE. Harper and Row, 1979.

Simpson, William. THE BUDDHIST PRAYING WHEEL: SYMBOLISM IN CUSTOM AND RELIGIOUS RITUAL.

Simson, Rosalind. PERSPECTIVES ON THE EPISTEMIC REGRESS PROBLEM. Ph.D. Dissertation, Yale University, 1979.

Sinisi, Vito F., "Leibniz's Law and the Antinomy of the Liar," PHILOSOPHY AND PHENOMENOLOGICAL RESEARCH, 30 (December 1969) 91-92.

[Skinner, B.F.], Hinman, Lawrence M., "Can Skinner Tell A Lie? Notes on the Epistemological Nihilism of B. F. Skinner," SOUTHERN JOURNAL OF PHILOSOPHY, 17, 1 (Spring 1979) 47-60.

Skinner, John E. [See work listed under Royce]

Skinner, R. C., "The Paradox of the Liar," MIND, 68 (1959) 322-35.

Skolem, Thomas. Review of Mostwoski's "Some Impredicative Definitions..." (q.v.), JOURNAL OF SYMBOLIC LOGIC, 16 (1951) 274-75.

Skolem, Thomas. Review of Mostowski's "Connection to the Paper..." 
(q.v.), JOURNAL OF SYMBOLIC LOGIC, 18 (1953) 343.

Skyrms, Brian, "Definitions of Semantical Reference and Self-Reference," NOTRE DAME JOURNAL OF FORMAL LOGIC, 17 (January 1976) 147-48.

Skyrms, Brian, "An Immaculate Conception of Modality," THE JOURNAL OF PHILOSOPHY, 75,7 (July 1978) 368-387. (Preferring a hierarchical to a self-referential interpretation of metalinguistic modality.)

Skyrms, Brian, "Notes on Quantification and Self-Reference," in R. L. Martin, PARADOX OF THE LIAR (q.v.).

Skyrms, Brian, "Return of the Liar: Three-Valued Logic and the Concept of Truth," AMERICAN PHILOSOPHICAL QUARTERLY, 7 (1970) 153-61.

Slezak, Peter. [See work listed under Gödel]

Sloman, Aaron, "Tarski, Frege and the Liar Paradox," PHILOSOPHY, 46 (April 1971) 133-47.

Smale, Gerald G. PROPHECY, BEHAVIOR AND CHANGE: AN EXAMINATION OF SELF-FULFILLING PROPHECIES IN HELPING RELATIONSHIPS. Routledge and Kegan Paul, 1977.

Small, Robin. [See work listed under Nietzsche]

Smart, J.J.C. [Co-authored works listed under Mackie, J.S.]

Smith, Brian Cantwell. REFLECTION AND SEMANTICS IN A PROCEDURAL LANGUAGE. Ph.D. Dissertation, Massachusetts Institute of Technology, 1982.

Smith, H. B., "The Theory of Multiple Implication and Its Application to the Generalized Problem of Epimenides," BULLETIN OF THE AMERICAN MATHEMATICAL SOCIETY, 35 (1929) 60-66.

Smith, John E., "The Reflexive Turn, the Linguistic Turn, and the Pragmatic Outcome," THE MONIST, 53 (Oct. 1969) 588-605.

Smith, John L. [See work listed under Plato]

Smith, Joseph Wayne, "Two Recent Self-Referential Arguments," AUSLEGUNG, 9, 3 (Winter 1982) 333-46. (Churchland, P.S. on determinism, and Everitt, N. on materialism.)

Smith, Michael P. [See work listed under Descartes]

Smith, P. [Co-authored work listed under Buckner, D.]

Smith, S. E., "The Reflexive Turn, the Linguistic Turn, and the Pragmatic Outcome," THE MONIST, 53, 4 (1969) 588-605.

Smorynski, Craig, "Calculating Self-Referential Statements, I: Explicit Calculations," STUDIA LOGICA, 38 (1979) 17-36.

Smorynski, Craig, "Calculating Self-Referential Statements: Guaspari Sentences of the First Kind," JOURNAL OF SYMBOLIC 
LOGIC, 46 (June 1981) 329-44.

Smorynski, Craig, "Fifty Years of Self-Reference in Arithmetic,"

NOTRE DAME JOURNAL OF FORMAL LOGIC, 22 (October 1981) 357-74.

Smorynski, Craig, "Modal Logic and Self-Reference," Essay 9 in D. Gabbay and F. Guenther (eds.), HANDBOOK OF PHILOSOPHICAL LOGIC, Vol. II: EXTENSIONS OF CLASSICAL LOGIC, D. Reidel, 1984.

Smullyan, Raymond. ALICE IN PUZZLE-LAND. William Morrow $\&$ Co., 1982.

Smullyan, Raymond, "Diagonalization and Self-Reference." Paper delivered orally at conference of the Society for Philosophy and Psychology, Chicago, April 5, 1981.

Smullyan, Raymond, and Hilary Putnam, "Exact Separation of Recursively Enumerable Sets Within Theories," PROCEEDINGS OF THE AMERICAN MATHEMATICAL SOCIETY, 11, 4 (1960) 574-77.

Smullyan, Raymond. 5000 B.C. --AND OTHER PHILOSOPHICAL FANTASIES. St. Martin's Press, 1983.

Smullyan, Raymond, "Fixed Points and Self-Reference," JOURNAL OF MATHEMATICS AND PHYSICS, (July, 1984).

Smullya, Raymond. FOREVER UNDECIDED -A PUZZLE GUIDE TO GÖDEL. Alfred A. Knopf, 1987.

Smullyan, Raymond. INCOMPLETENESS AND UNDECIDABILITY. Oxford University Press, 1987.

Smullyan, Raymond. THE LADY OR THE TIGER? --AND OTHER LOGICAL PUZZLES. Alfred A. Knopf, 1982.

Smullyan, Raymond, "Languages in Which Self-Reference is Possible," JOURNAL OF SYMBOLIC LOGIC, 22, 1 (1957) 55-67. (See review by Shoenfield, J. R.)

Smullyan, Raymond, "Logicians Who Reason About Themselves --Theoretical Aspects of Reasoning About Knowledge," PROCEEDINGS OF THE 1986 CONFERENCE. Morgan Kaufman Publishers, 1986, pp. 341-52.

Smullyan, Raymond. TO MOCK A MOCKINGBIRD. Alfred A. Knopf, 1985.

Smullyan, Raymond, "Modality and Self-Reference --Intensional Mathematics," STUDIES IN LOGIC AND THE FOUNDATIONS OF MATHEMATICS, 113 (1985) 292-311.

Smullyan, Raymond, "Quotation and Self-Reference," in Steven J. Bartlett and Peter Suber (eds.), SELF-REFERENCE (q.v.). Smullyan, Raymond. THEORY OF FORMAL SYSTEMS. Annals of Mathematical Studies, 1961. 
Smullyan, Raymond. THIS BOOK NEEDS NO TITLE: A BUDGET

OF LIVING PARADOXES. Prentice-Hall, 1980.

Smullyan, Raymond, "Uniform Self-Reference," STUDIA LOGICA (Tarski Symposium), 44, 4 (1985) 439-45.

Smullyan, Raymond. WHAT IS THE NAME OF THIS BOOK? THE RIDDLE OF DRACULA AND OTHER LOGICAL PUZZLES. Prentice-Hall, 1978.

Soll, Ivan. [See work listed under Nietzsche]

Sommers, F., "On Concepts of Truth in Natural Languages," REVIEW OF METAPHYSICS, 23 (1969) 259-86. (See Martin, R.L.)

Sommers, F., "Predictability," in Max Black (ed.), PHILOSOPHY IN AMERICA. Cornell University Press, 1964. (See Martin, R.L.)

Sonnenfeld, A. [See work listed under Malraux]

Sorensen, Roy A., "Recalcitrant Variations of the Prediction Paradox," AUSTRALASIAN JOURNAL OF PHILOSOPHY, 60, 4 (December 1982) 355-62.

Spade, Paul Vincent, "General Semantic Closure," JOURNAL OF PHILOSOPHIC LOGIC, 6 (June 1977) 209-21.

Spade, Paul Vincent. THE MEDIEVAL LIAR: A CATALOGUE OF THE INSOLUBILIA LITERATURE. Toronto: Pontifical Institute of Medieval Studies, 1975.

Spade, Paul Vincent, "Ockham on Self-Reference," NOTRE DAME JOURNAL OF FORMAL LOGIC, 15 (April 1974) 298-300.

Spanos, William V., "Heidegger, Kierkegaard, and the Hermeneutic Circle: Towards a Postmodern Theory of Interpretation as Dis-closure," in Spanos (ed.), MARTIN HEIDEGGER AND THE QUESTION OF LITERATURE: TOWARDS A POSTMODERN LITERARY HERMENEUTICS, pp. 115-148. Indiana University Press, 1976. Also printed in BOUNDARY 2, 4, 2 (Winter 1976) 455-88.

Sparkes, A.W., "'Begging the Question'," JOURNAL OF THE HISTORY OF IDEAS, 27 (1966) 462-63.

Spinelli, Aldo. LOOPINGS. Amsterdam: Multi Art Points Edition, 1976. (A self-describing text.)

Spitzer, A. [See work listed under Plato]

Stack, George J., "Reflexivity, Prediction and Paradox," DIALOGOS, 13 (1978) 91-101.

Stack, Michael, "Self-Refuting Arguments," METAPHILOSOPHY, 14, 3-4 (July-Oct. 1983) 327-34.

Stambaugh, Joan. [See work listed under Nietzsche]

Steel, T., "In Reply to a Paradox," MIND, 80 (Oct. 1971) 616.

Steiner, Mark. Review of Chihara's ONTOLOGY AND THE VICIOUS CIRCLE PRINCIPLE (q.v.), JOURNAL OF 
PHILOSOPHY, 72 (April 10,1975) 184-96.

Stenius, Erik, "Semantic Antinomies and the Theory of Well-Formed Rules," THEORIA, 36 (1970) 142-60.

[Stern, Kenneth], See: Hart, J.A. and Dees, J.G.

Stern, R. H., "Priority Paradoxes in Patent Law," VANDERBILT LAW REVIEW, 16 (1962) 131.

[Sterne, Laurence], Diamond, R.J., "Resolution of the Paradox of Tristram Shandy," PHILOSOPHY OF SCIENCE, 31 (1964) 55-58.

[Sterne, Laurence], Swearingen, James E. REFLEXIVITY IN "TRISTRAM SHANDY". Yale University Press, 1977.

Stone, John David. THE SEMANTIC PARADOXES IN NATURAL LANGUAGES. Ph.D. Dissertation, University of Texas at Austin, 1976.

Stone, Roy, "Affinities and Antinomies in Jurisprudence," CAMBRIDGE LAW JOURNAL, (1964) 266-85. (Inter alia, that Gödel's theorem applies to legal systems.)

Stone-de Montpensier, Roy L., "The Compleat Wrangler," MINNESOTA LAW REVIEW, 50 (1966) 1001-25. (Same author as previous; also defends thesis that Gödel's theorem applies to law.)

Stone-de Montpensier, Roy L., "Logic and Law: The Precedence of Precedents," MINNESOTA LAW REVIEW, 51 (1967) 655-74. Strawson, P. F., "Paradoxes, Posits, and Propositions," PHILOSOPHICAL REVIEW, 76 (1967) 214-19.

[Strawson, P. F.], See: Rotenstreich, N.

Stroll, A. "Is Everyday Language Inconsistent?," MIND, 63 (1954) 219-25. (See review by Thomson, J.F.)

Strom, James J., "On Squaring the Circles of Logic," ANALYSIS, 37 (1977) 127-29.

Stubbs, A.C. [See work listed under Descartes]

Suber, Peter, "Nomic," in Douglas R. Hofstadter, "Metamagical Themas: About Nomic: A Heroic Game That Explores the Reflexivity of the Law," SCIENTIFIC AMERICAN, 246, 6 (June 1982) 16-28. Reprinted, e.g., in OXYMORON 12, 12 (August 10,1982) unpaginated, with comments by Jaap Jacobs; slightly revised, in Douglas R. Hofstadter, METAMAGICAL THEMAS, Basic Books, 1985.

Suber, Peter, "A Bibliography of Works on Reflexivity," in Steven J. Bartlett and Peter Suber (eds.), SELF-REFERENCE (q.v.).

Suber, Peter, "Logical Rudeness," in Steven J. Bartlett and Peter Suber (eds.), SELF-REFERENCE (q.v.).

Suber, Peter. [Co-edited work listed under Bartiett, S.J.] 
Suits, Bernard, "Games and Paradox," PHILOSOPHY OF SCIENCE, 36 (September 1969) 316-21.

Swearingen, James E., "Reflexivity and the Decentered Self," in Steven

J. Bartlett and Peter Suber (eds.), SELF-REFERENCE (q.v.).

Swearingen, James E. [See work listed under Sterne, L.]

Swiggert, Peter, "Quine's Logic and the Class Paradox," MIND, 84, 335 (July 1975) 321-37.

Swiggert, Peter, "Self-Reference in Formal Lanaguages," NOTRE

DAME JOURNAL OF FORMAL LOGIC, 15 (October 1974) 608-12.

Swineburne, Richard, "Omnipotence," AMERICAN PHILOSOPHICAL QUARTERLY, 10 (1973) 231-37.

$$
-\mathrm{T} \text { - }
$$

Talland, G. A., "The Assessment of Group Opinion by Leaders and Their Influence on Its Formation," JOURNAL OF ABNORMAL AND SOCIAL PSYCHOLOGY, 49 (1954) 431-34.

Tammelo, Ilmar, "The Antinomy of Parliamentary Sovereignty," ARCHIV FÜR RECHTS-UND SOZIALPHILOSOPHIE, 44 (1958) 495-516. (See review by Hintikka, J.)

Tarski, A. "The Concept of Truth in Formalized Languages," in LOGIC, SEMANTICS, METAPHYSICS: PAPERS FROM 1923-38, pp 152-278. Oxford University Press, 1956.

Tarski, A., "The Semantic Conception of Truth and the Foundations of Semantics," PHILOSOPHY AND PHENOMENOLOGICAL RESEARCH, 4 (1944) 341-76.

Tarski, A., "Truth and Proof," SCIENTIFIC AMERICAN, 220 (1969) 63-77.

[Tarski, A.], See: Stegmuller, W.; Rivetti Barbo, F.; Sloman, A.

Taubes, Jacob, "The Realm of Paradox," THE REVIEW OF METAPHYSICS, 7 (1954) 482-91.

Taylor, Charles, "Man as Self-Interpreting Animal." Paper delivereed orally at Convention of American Philosophical Association, University of California at Berkeley, March 22, 1983.

Taylor, R. Gregory. MATHEMATICAL DEFINABILITY AND THE PARADOXES. Ph.D. Dissertation, Columbia University, 1983.

Teensma, E. THE PARADOXES. Assen: Van Gorcum, 1965.

Teloh, Henry, "Self-Predication of Anaxagorean Causation in Plato," APEIRON, 9 (1975) 15-23.

Thomas, Ivo, "The Written Liar and Thomas Oliver," NOTRE DAME 
JOURNAL OF FORMAL LOGIC, 6 (1965) 201-08.

Thomas, William J. [See work listed under Plato]

Thompson, M. H., Jr., "The Logical Paradoxes and Pierce's [sic] Semiotic," JOURNAL OF PHILOSOPHY, 46 (1949) 513-36.

(See review by Turquette, A.P.)

Thomsen, Dietrick E., "Self-Assembly: Biology $<->$ Physics: Biology and Physics Can Illuminate Fundamental Questions," SCIENCE NEWS, 121, 20 (May 15, 1982) 334.

Thomson, J. F., "On Some Paradoxes," in R. J. Butler (ed.), ANALYTIC PHILOSOPHY, pp. 104-19. Oxford: Basil Blackwell, 1962. (See Anderson, A.R.)

Thomson, J. F., Review of Popper's "Self-Reference and Meaning..." (q.v.), Evans's "On Some Semantic Illusions" (q.v.), Stroll's "Is Everyday Language Inconsistent?" (q.v.), JOURNAL OF SYMBOLIC LOGIC, 21 (1956) 381.

[Thoreau], Tuerk, Richard Carl. CENTRAL STILL: CIRCLE AND SPHERE IN THOREAU'S PROSE. The Hague: Mouton, 1975.

Tipler, Frank J., "General Relativity and the Eternal Return," in F. J. Tipler (ed.), ESSAYS IN GENERAL RELATIVITY. Academic Press, 1980.

Thumak, Jeffrey. [See work listed under Descartes]

Todd, William. [Co-authored work listed under Rechtin, L.]

Tollefsen, Olaf, "The Equivocation Defense of Cognitive Relativism," in Steven J. Bartlett and Peter Suber (eds.), SELF-REFERENCE (q.v.).

Tollefsen, Olaf. [Co-authored works listed under Boyle, J.M.]

Toms E., "The Liar Paradox," PHILOSOPHICAL REVIEW, 65 (1956) 542-47. (See reviews by Bennet, J. and Sibajiban.)

Toms, E., "The Reflexive Paradoxes," PHILOSOPHICAL REVIEW, 61 (1952) 557-67. (See reply by Geach.)

Toms, E., "Reply to a Note on the Liar Paradox," PHILOSOPHICAL REVIEW, 67 (1958) 101-05. (See review by Bennet, J.)

Trigg, George L. et al., "In Your Own Write," PHYSICAL REVIEW LETTERS, 42 (1979) 748. (Collection of self-violating rules and maxims.)

Trompf, G. W.. THE IDEA OF HISTORICAL RECURRENCE IN WESTERN THOUGHT: FROM ANTIQUITY TO THE REFORMATION. University of California Press, 1979.

Tucker, John, A comment on I. J. Good's "Note on Richard's Paradox," MIND, 78 (1969) 272.

Tucker, John, "Gödel and Epimenides," PROCEEDINGS OF THE ARISTOTELIAN SOCIETY, 59 (1958-59) 25-48.

Tucker, John, "An Outline for a New Program for the Foundations of 
Mathematics," PHILOSOPHIA MATHEMATICA, 6 (June-December 1969) 28-37.

Tucker, John, "Philosophical Arguments," PROCEEDINGS OF THE ARISTOTELIAN SOCIETY, supp, vol. 39 (1965) 47-64.

Tuerk, Richard Carl. [See work listed under Thoreau]

Turquette, A. R. Review of Thompson's "The Logical Paradoxes and

Pierce's Semiotic," (q.v.), JOURNAL OF SYMBOLIC LOGIC, 16 (1951) 214-15.

Tustin, Arnold, "Feedback," SCIENTIFIC AMERICAN, 187, 3 (Sept. 1952) 48-55, reprinted in SCIENCE, CONFLICT AND SOCIETY: READINGS FROM SCIENTIFIC AMERICAN, W. H. Freeman and Co., 1969.

Tymoczko, Thomas, "An Unsolved Puzzle About Knowledge," THE PHILOSOPHICAL QUARTERLY, 34, 137 (Oct. 1984). (On the sentence, "No one knows that this sentence is true.")

Tyree, Alan L., "Circular Priorities in Secured Transactions," AMERICAN MATHEMATICAL MONTHLY, 87 (1980) 186-93.

$$
-\mathrm{U} \text { - }
$$

Ukraintsev, B. S., "Self-Controlling Processes and Causality," VOPROSY FILOSOFII, no. 4 (1968).

Ushenko, A. P., "An Addendum to the Note on the Liar Paradox," MIND, 66 (1957) 98. (See review by Bennet, J.)

Ushenko, A. P., "A Modification of the Theory of Types," THE MONIST, 44 (1934) 147-49.

Ushenko, A. P., "A New Epimenides," MIND, 46 (1937) 549-50. (See reviews by Encarnacion, J., and Langford, C. H.)

Ushenko, A. P., "A Note on the Liar Paradox," MIND 64 (1955) 543. (See review by Bennet, J.)

Ushenko, A. P., "A Note on the Semantic Conception of Truth," PHILOSOPHY AND PHENOMENOLOGICAL RESEARCH, 5 (1944) 104-07.

Ushenko, A. P. THE PROBLEMS OF LOGIC. [especially Ch. 2]. Princeton University Press, 1941. (See reviews by Nelson, E., and Wedberg, A.)

Ushenko, A. P., "Undecidable Statements and Metalanguage," MIND, 53 (1944) 258-62. (See review by McKinsey, J.C.C.)

$$
-\mathrm{V} \text { - }
$$

[Valle-Inclan], Boudreau, H. L., "Circular Structure of Valle-Inclan's 
'Ruedo Iberico'," PUBLICATIONS OF THE MODERN LANGUAGE ASSOCIATION, 82 (March 1967) 128-35.

Van Cleve, J. [See work listed under Descartes]

van Fraassen, Bas C., "Inference and Self-Refereence," SYNTHESE, 21 (Oct. 1970) 425-38.

van Fraassen, Bas C., "Presupposition, Implication, and Self-Reference," JOURNAL OF PHILOSOPHY, 65 (March 1968) $136-51$.

van Fraassen, Bas C., "Presuppositions, Supervaluations, and Free Logic," in K. Lambert (ed.), THE LOGICAL WAY OF DOING THINGS. Yale University Press, 1969.

van Fraassen, Bas C., "Truth and Paradoxical Consequences," in R. L. Martin, PARADOX OF THE LIAR (q.v.).

Van Heijenoort, John, "Logical Paradoxes," in Paul Edwards (ed.), ENCYCLOPEDIA OF PHILOSOPHY, 5:45-51. Macmillan and the Free Press, 1967.

Van Heijenoort, John (ed.). FROM FREGE TO GÖDEL: A SOURCE BOOK IN MATHEMATICAL LOGIC, 1978-1931. Harvard University Press, 1967.

Varela, Francisco, "A Calculus for Self-Reference," INTERNATIONAL JOURNAL OF GENERAL SYSTEMS, 2 (1975) 1-25.

Varela, Francisco. PRINCIPLES OF BIOLOGICAL AUTONOMY. D. Reidel, 1979.

Varela, Francisco. [Co-authored work listed under Maturana, H.R.] Veatch, H. B., and Young, T., "Metaphysics and the Paradoxes," REVIEW OF METAPHYSICS, 6 (1952) 199-218.

Vetterling, Mary K., "Discussion: More on Reflexive Predictions," PHILOSOPHY OF SCIENCE, 43 (1976) 278-82.

Visader, John, "The Use of Paradox in Urboric Philosophies," PHILOSOPHY EAST AND WEST, 28 (October 1978) 455-67.

[Vitruvius], Plommer, H., "Circle of the Winds in Vitruvius i.6," CLASSICAL REVIEW, n.s. 21 (June 1971) 159-62.

Vlastos, Gregory. [See work listed under Plato]

Von Foerster, H., "On Self-Organizing Systems and Their Environments," in Yovitts, M. and Cameron, S. (eds.), SELF-ORGANIZING SYSTEMS (q.v.), 1960, pp. 31-50.

Von Foerster, H., and Zopf, G.W. Jr. (eds.). PRINCIPLES OF SELF-ORGANIZATION. Pergamon, 1960.

Von Foerster, H. [Co-authored work listed under Pask, G.]

von Wright, G. H., "The Heterological Paradox," SOCIETAS SCIENTARIUM FENNICA COMMENTATIONES PHYSICO-MATHEMATICAE, vol. 24. 
[von Wright, G. H.], See: Woods, J. and Walton, D.

Wagner, Roy. SYMBOLS THAT STAND FOR THEMSELVES. University of Chicago Press, 1986. (Symbols in the creation of culture and meaning systems.)

Walton, Douglas, "Are Circular Arguments Necessarily Vicious?" AMERICAN PHILOSOPHICAL QUARTERLY, 22, 4 (Oct. 1985) 263-74.

Walton, Douglas and Lynn M. Batten, "Games, Graphs and Circular Arguments," LOGIQUE ET ANALYSE, 106 (1984) 133-164.

Walton, Douglas, "Mill and DeMorgan on Whether the Syllogism is a Petitio," INTERNATIONAL LOGIC REVIEW, 8 (1977) 57-68.

Walton, Douglas. LOGICAL DIALOGUE-GAMES AND FALLACIES. University Press of America, 1984.

Walton, Douglas, "The Omnipotence Paradox," CANADIAN JOURNAL OF PHILOSOPHY, 4 (1975) 705-15.

Walton, Douglas, "Petitio Principii and Argument Analysis," in R. H. Johnson and J. A. Blair (eds.), INFORMAL LOGIC, pp. 40-54. Point Reyes, California: Edgepress, 1980.

Walton, Douglas. [Co-authored works listed under Woods, J.]

Wand-Schneider, Dieter, "Concerning the Antinomy Problem of Logic," RATIO, 16, I (June, 1974) 82-102.

Wang, H., "The Irreducibility of Impredicative Principles," MATHEMATISCHE ANNALEN, 125 (1952) 56-66. (See review by McNaughton, $\mathrm{R}$.)

Wang, H., "Undecidable Sentences Generated By Semantic Paradoxes," JOURNAL OF SYMBOLIC LOGIC, 20 (1955) $31-42$.

Waugh, Patricia. METAFICTION: THE THEORY AND PRACTICE OF SELF-CONSCIOUS FICTION. Methuen, 1984.

Webb, Judson C., "The Mechanization of Self-Reference." Paper delivered orally at Conference of the Society for Philosophy and Psychology, Chicago, April 5, 1981.

Wedberg, A., Review of Ushenko's THE PROBLEMS OF LOGIC. (q.v.), PHILOSOPHICAL REVIEW, 52 (1943) 208-11.

Weinberg, J., "A Possible Solution of the Heterological Paradox," PHILOSOPHICAL REVIEW, 46 (1937) 657-59. (See review by Church, A.)

Welch, Robert S. [See work listed under Descartes]

Wheeler, Samuel C. III, "Megarian Paradoxes as Eleatic Arguments," 
AMERICAN PHILOSOPHICAL QUARTERLY, 20, 3 (July 1983) 287-96.

Whewell, David, "Self-Reference and Meaning in a Natural Language," in Steven J. Bartlett and Peter Suber (eds.), SELF-REFERENCE (q.v.).

Whewell, David, "Transcendental Deductions and the A Priori Legitimation of Knowledge Claims," PROCEEDINGS OF THE FIFTH INTERNATIONAL KANT CONGRESS, I.1. Bouvier Verlag Herbert Grundmann, 1981. (In part devoted to self-guaranteeing and self-refuting statements.)

White, "A Problem in Priorities," OHIO LAW REPORTER, 25 (1926)

116. (On circular priorities.)

Whitehead, Alfred North, and Bertrand Russell. PRINCIPIA MATHEMATICA. Volume I, Chapter II, Section I: "The Vicious Circle Principle." Section II: "The Contradictions." Cambridge University Press, 1910.

[Whitehead, A.N., and Russell, B.], Brown, James M., "Bernays's Non-Circular Proof of the Non-Independence of the Fourth Axiom of 'Principia Mathematica'," ANALYSIS, 36 (1976) 207-08.

[Whitehead, A.N., and Russell, B.], Danquah, Joseph, "The Circularity of the Proof of the Non-Independence of the Fourth Axiom of 'Principia Mathematica'," ANALYSIS, 36 (1976) 110-11.

Whitely, C. H., "Let Epimenides Lie!," ANALYSIS, 19 (1958) 23-24. (See review by Bennet, J.)

Wiener, Norbert, "Cybernetics," SCIENTIFIC AMERICAN, 179, 5 (Nov. 1948) 14-19. Reprinted in SCIENCE, CONFLICT AND SOCIETY: READINGS FROM SCIENTIFIC AMERICAN. W. H. Freeman and Co., 1969.

Wiener, Norbert. CYBERNETICS: OR CONTROL AND COMMUNICATION IN THE ANIMAL AND THE MACHINE. Massachusetts Institute of Technology Press, $2 \mathrm{~d}$ ed. 1961.

Wiley, Margaret L. [See work listed under Melville]

Williams, John N., "Justified Belief and the Infinite Regress Argument," AMERICAN PHILOSOPHICAL QUARTERLY, 18,1 (Jan. 1981) .

Williams, M.E., "Begging the Question," DIALOGUE, 6 (1968) 567-70. (Reply to Johnson, O.A.)

Wilson, R.R., "This Is Not a Meta-Review of Three Books on Metafiction, But What Account Should Be Given of a Self-Referential Title," CANADIAN REVIEW OF COMPARATIVE LITERATURE, 12, 2 (June 1985) 292-305. 
Witemeyer, H.H. [See work listed under Emerson]

[Wittgenstein], Dumitriu, Anton, "Wittgenstein's Solution of the

Paradoxes," JOURNAL OF THE HISTORY OF PHILOSOPHY, 12 (1974) 227-37.

[Wittgenstein], Goldstein, Laurence, "Wittgenstein and the Logico-Semantical Paradoxes," RATIO, 25, 2 (Dec. 1983).

[Wittgenstein], Miller, Richard W., "Solipsism in the TRACTATUS,"

Section: "From the Denial of Self-Reference to the Denial of Other Minds," pp. 60-65; Section: "Psychic Representation and the Denial of Self-Reference," pp. 65-70, JOURNAL OF THE HISTORY OF PHILOSOPHY, 18, 1 (Jan. 1980) 57-74.

[Wittgenstein], Worthington, B.A., "Ethics and the Limits of Language in Wittgenstein's TRACTATUS," Section 4: "Self-Reference and Self-Consciousness," pp. 494-96, JOURNAL OF THE HISTORY OF PHILOSOPHY, 19, 4 (1981) 481-96.

[Wittgenstein, Ludwig], See: Chihara, C.S.

Wolf, Eleanor, "The Invasion-Succession Sequence as a Self-fulfilling Prophecy," JOURNAL OF SOCIAL ISSUES, 13 (Oct. 1957) 7-20.

Wolfe, Julian, "Omnipotence," CANADIAN JOURNAL OF PHILOSOPHY, 1 (1971) 245-48.

Wolock, F.W. [Co-authored work listed under John, J.A.]

Wood, Leger. THE ANALYSIS OF KNOWLEDGE. Princeton University Press, 1941. (Discusses self-referentially inconsistent arguments, pp. 193-203.)

Woodruff, Peter W., "Paradox and Truth Value Gluts," paper delivered orally at Convention of the American Philosophical Convention, March 22, 1984, Long Beach.

Woodruff, Peter W., "Paradox, Truth, and Logic. Part I: Paradox and Truth," JOURNAL OF PHILOSOPHICAL LOGIC, 13 (1984) 213-232.

Woodruff, Peter W. [Co-authored work listed under Martin, R.L.]

Woods, John and Douglas Walton, "Arguing in a Circle," Chapter 7 of their ARGUMENT: THE LOGIC OF THE FALLACIES. McGraw-Hill, 1981.

Woods, John and Douglas Walton, "Arresting Circles in Formal Dialogues," JOURNAL OF PHILOSOPHICAL LOGIC, 7 (1978) 73-90.

Woods, John and Douglas Walton, "Circular Demonstration and von Wright-Geach Entailment," NOTRE DAME JOURNAL OF FORMAL LOGIC. 20, 4 (October 1979) 768-71.

Woods, John and Douglas Walton, "The Petitio: Aristotle's Five Ways," CANADIAN JOURNAL OF PHIILOSOPHY, 12, 1 
(March 1982) 77-100.

Woods, John and Douglas Walton, "Petitio Principle," SYNTHESE, 31 (1975) 107-27.

Woods, John and Douglas Walton, "Petitio and Relevant Many-Premissed Arguments," LOGIQUE ET ANALYSE, 77-78 (1977) 97-110.

Woods, John and Douglas Walton, "Question-Begging and Cumulativeness in Dialectical Games," NOUS, 16, 4 (November 1982) 585-605.

[Wordsworth], Gill, S., "Affinities Preserved: Poetic Self-Reference in

Wordsworth," STUDIES IN ROMANTICISM, 24, 4 (Winter 1985) 531-50.

[Wordsworth], See: Jay, P.

Wormell, C. P., "On the Paradoxes of Self-Reference," MIND, 67 267-71.

Worthington, B.A. [See work listed under Wittgenstein]

Wright, Edmund L., "Logic as an Intention-Matching System: A

Solution to the Paradoxes," JOURNAL OF THE BRITISH SOCIETY FOR PHENOMENOLOGY, 10, 3 (Oct. 1979) 164-71.

\section{- Y -}

Yartz, Frank T. [See work listed under Plato]

Yoder, R.A., "The Equilibrist Perspective: Toward A Theory of American Romanticism," STUDIES IN ROMANTICISM, 12 (1973) 705-40. (On circular themes in American Romanticism.)

Young, Arthur M. THE REFLEXIVE UNIVERSE: EVOLUTION OF CONSCIOUSNESS. A Merloyd Lawrence Book, Delacorte Press, 1976.

Young, Robert, "A Sound Self-Referential Argument?" REVIEW OF METAPHYSICS, 27 (September 1973) 112-19.

Young, T. [Co-authored work listed under Veatch, H.B.]

[Young], See: Marshall, J. et. al.

Yourgrau, Wolfgang. [See work listed under Gödel]

Yovitts, Marshall C., and Cameron S. (eds.). SELF-ORGANIZING SYSTEMS. Pergamon, 1960.

Yovitts, Marshall C., George T. Jacobi, and Gordon D. Goldstein (eds.), SELF-ORGANIZING SYSTEMS. Washington: Spartan Books, 1962. (Conference on Self-Organizing Systems, Chicago, 1962.)

Yudin, E.G. [Co-authored work listed under Blauberg, I.V.] 
Yuting, S., "Two Semantical Paradoxes," JOURNAL OF SYMBOLIC LOGIC, 20 (1955) 119-20.

$$
-\mathbf{Z} \text { - }
$$

Zeleny, M. (ed.). AUTOPOIESIS: A THEORY OF LIVING ORGANIZATION. D. Reidel, 1981.

Zirlin, R.B. [See work listed under Descartes]

Zopf, G.W. Jr. [Co-authored work listed under Von Foerster, H.]

Zuboff, Arnold. [See work listed under Nietzsche] 


\section{Section Three: Cross-Reference Lists}

- Computer Science. Includes cybernetics. See also: Feedback, Reflexivity in Natural Science.

Ashby, W.R. (1947)

Ashby, W.R. (1962)

Ashby, W.R. and Riguet, J.

Babcock, M.L. et al.

Braines, S.N., Napalkov, A:V., and Shreider, I.A. (1959)

Braines, S.N., Napalkov, A.V. (1960)

[Dworkin] Farago, J.

Farley, B.G. (1960)

Farley, B.G., and Clark, W.A. (1955)

Foerster, H. von (1979)

Foerster, H. von (1981)

Foerster, H. von (1949-55)

[Gödel] Desmonde, W.H.

Hofstadter, D.R. (1979)

Hofstadter, D.R. (1981)

Hofstadter, D.R. (1982)

Hofstadter, D.R. (1983)

Kanerva, P.

Kimball, R.B.

Nicolis, G.

Pask, G., and Von Foerster, H. (1960)

Penrose, L.S. (1959)

Penrose, L.S. (1959)

Roth, G. and Schwegler, H. (eds.)

Saridis, G.N.

Shoch, J.F. and Hupp, J.A.

Sigler, J.A.

Smith, B.C.

Von Foerster, H. (1960)

Von Foerster, H., and Zopf. G.W. Jr. (1960)

Webb, J.C.

Wiener, N. (1978)

Wiener, N. (1961)

Yovitts, M.C., and Cameron, S.

Yovitts, M.C., Jacobi, G.T., Goldstein, G.D. 
- Dissertations.

Back, A.T. (reduplication)

Bahnsen. G.L. (self-deception)

Baldwin, H.W. (self-refutation)

Bartlett, S.J. (1970) (conceptual pathology)

[Descartes] Markie, P. (Cartesian circle)

[Descartes] Welch, R.S. (Cartesian circle)

[Descartes] Zirlin, R.B. (Cartesian circle)

Dowden, H. (liar)

Elliott, L. (fiction)

Füredy, V.Y.G.M. (plays within plays)

Gibbons, T.F. (self-reference)

Hall, J. (self-prediction, free will)

Hawthorn, J. (liar and theories of truth)

[Heidegger] N.B. (hermeneutic circle in Being and Time)

Lightbody, T.P. (liar)

Miller, M.M. (self-referring knowledge claims)

Niemi, G.W. (self-reference and modality)

[Nietzsche] Baker, T.A. (will to power and recurrence)

[Nietzsche] Reeves, S. (recurrence)

[Nietzsche] Williams, R. (recurrence)

[Plato] Apolloni, D. (self-predication)

[Plato] Gould, C.S. (self-predication)

[Plato] Haynes, R.P. (self-predication)

[Plato] Pinto, W.L. (self-predication)

[Plato] Smith, J.L. (false statements)

Portmess, L. (time and paradox)

Potter, R.C. (liar and intentionality)

Rorty, A.O. (self-reference, error, method)

Sell, J.J. (self-predication of 'Jesus')

Shafer, I.H. (infinite circle in Hegel, Jung, Hesse)

Simson, R. (epistemic regress)

Smith, B.C. (reflection in procedural languages)

Smith, M.P. (virtuous circle in Descartes)

Stone, J.D. (semantic paradoxes, natural languages)

Taylor, R.G. (mathematical definability and paradox)

- Feedback.

Includes circular causation. See also: Computer Science, Reflexivity in Natural Science, Self-Fulfilling Prophecies. 
Bertalanffy, L. von

Bowerman, W.R.

Daye, D.D. (1979)

Foerster, H. von

George, L.C.

Henshel, R.L. (1975)

Nicolis, G.

Noelle-Neumann, E.

Saridis, G.N.

Tustin, A.

Ukraintsev, B.S.

Wiener, N. (1961)

Yovits, M.C., Jacobi, G.T., Goldstein, G.D.

- Freedom.

Includes free will, determinism. See also: Metaphysics, Self-Refutation.

Bartlett, S.J. (1979) (review)

Boyle, J.M. (1988)

Boyle, J.M., Grisez, G., Tollefsen, O. (1972)

Boyle, J.M., Grisez, G., Tollefsen, O. (1976)

Churchland, P.S.

Fishkin, J.

[Gödel] Chihara, C.S.

[Gödel] Coder, D.

[Gödel] Desmonde, W.H.

[Gödel] Hanson, W.W.

Hall, J.

Knaster, S.

Konyndyk, $\mathrm{K}$.

Lucas, J.R.

Popper, K. (1983)

Scriven, M.

[Scriven] Lewis, D.K. and Richardson, J.S.

Smith, J.W.

- Hermeneutic Circle.

See also: Reflexivity in Literature, Self-Justification.

Brody, $\mathrm{M}$. 
Clark, $\mathrm{M}$.

Enc, B.

Gelven, M.

[Hegel] Yerkes, J.

Hirsch, E.D.

Hoy, D.C.

Jaspers, $\mathrm{K}$.

Llewelyn, J.

Marino, A.

Myers, C.M.

Spanos, W.V.

Taylor, C.

- Heterological.

See also: Paradox, Self-Reference.

Baylis, C.

Bowden, L.

Cargile, J. (1967)

Church, A. (1950)

Church, A. (1938)

Fitzpatrick, P.J.

Gregory, J.

Killalea, J.N.

Landsberg, P.T.

Lawrence, N.

McDonald, $M$.

Mackie, J.S. and Smart, J.J.C. (1953)

Mackie, J.S. and Smart, J.J.C. (1954)

Martin, R.L. (1968)

Meager, $\mathrm{R}$.

Odegard, D.

Orey, S.

Ryle, G.

von Wright, G.H.

Weinberg, J.

- History.

Includes cyclical theories, recurrence. See also: Metaphysics, Reflexivity in Religion.

Boas, G. 
Borkenau, F.

Caims, G.E.

Callois, $R$.

Copleston, F.C.

Corbin, $\mathrm{H}$.

Eliade, $\mathrm{M}$.

[Empedocles] Long, A.A.

[Empedocles] O'Brien, D.

Heidegger, $\mathrm{M}$.

Jaki, S.L.

Long, A.A.

Manuel, F.E.

Murillo, L.A.

[Nagel] Nissen, L.

[Nietzsche] Altizer, T.J.J.

[Nietzsche] Baker, T.A.

[Nietzsche] Brush, S.G.

[Nietzsche] Clegg, J.S.

[Nietzsche] Danto, A.

[Nietzsche] Hatab, L.J.

[Nietzsche] Kain, P.J.

[Nietzsche] Klossowski, P.

[Nietzsche] Krueger, J.

[Nietzsche] Löwith, K.

[Nietzsche] Reeves, S.

[Nietzsche] Soll, I.

[Nietzsche] Stambaugh, J.

[Nietzsche] Williams, R.

[Nietzsche] Zuboff, A.

Onians, R.B.

Tipler, R.B.

Trompt, G.W.

- Impredication.

See also: Paradox, Russell's Paradox, Self-Description, Self-Application, Self-Reference, Theory of Types.

Cargile, J. (1979)

Dingler, $\mathrm{H}$.

Gorsky, D.P.

Hintikka, J. (1958)

McNaughton, R. 
Mostowski, A. (1951-52)

Mostowski, A. (1950-51)

O'Carroll, M.J. (1967)

Parsons, C.

[Plato] Apolloni, D.

[Plato] Clegg, J.S.

[Plato] Driscoll, J.A.

[Plato] Haynes, R.P.

[Plato] Nehamas, A.

[Plato] Pinto, W.L.

[Plato] Savan, D.

[Plato] Vlastos, G.

[Plotinus] Fiedler, J.

Saito, $\mathrm{S}$.

Sell, J.J.

Skolem, T. (1951)

Teloh, $\mathrm{H}$.

Wang, H. (1952)

- Liar.

See also: Paradox, Self-Reference.

Agassi, J. (variations)

Anderson, A.R. (St. Paul)

Aqvist, L. (1982) (in modal logic)

Ashworth, E.J. (1974) (review)

Ashworth, E.J. (1977) (Thomas Bricot)

Ashworth, E.J. (1976) (medieval)

Bar-Hillel, Y. (1947) (revival)

Bar-Hillel, Y. (1968) (cogito)

Bar-Hillel, Y. (1957) (new light)

Bateson, G. (play)

Bennet, J. (1962) (review)

Bochenski, I.M. (scholastic solution)

Buckner, D., and P. Smith (quotation and)

Burdian, J. (medieval)

Burge, T. (1984) (applied to thoughts and beliefs)

Cargile, J. (1969) (review)

Church, A. (1946) (review)

Cohen, L.J. (1961) (talk so much)

Donnellan, K. (1970) (categories)

Donnellan, K. (1957) (note) 
Dowden, B.H. (theory of truth)

Encamacion, J. (Ushenko's version)

Fitch, F.B. (1970) (comment, suggestion)

Hawthorn, J. (and theories of truth)

Herzberger, H.G. (1982)

Hicks, J.C. (in legal reasoning)

Kanger, S. (review)

Keene, G.B. (1983) (and self-referent inference)

Koyre, A. (1946) (general)

Koyre, A. (1947) (reply)

Langford, C.H. (1947) (liar type)

Langford, C.H. (1938) (Ushenko's version)

Lightbody, T.P. (recent approaches)

Martin, R.L. (1970) (anthology)

Martin, R.L. (1967) (toward solution)

Martin, R.L. (1984) (second anthology)

Martinich, A.P. (a solution)

Mates, B. (1981) (genuine problem)

Meager, R. (and heterology)

Odegard, D. (parasitical reference)

Pollock, J.L. (strikes back)

Post, J.F. (1970) (possible liar)

Post, J.F. (1978) (possible liar)

Post, J.F. (1973) (shades of liar)

Priest, G. (1988) (unstable solutions to)

Prior, A.N. (1958) (general)

Regnell, H. (1968) (new approach)

Roberts, L.N. (medieval)

Rozeboom, W.W. (still lying?)

Schoenberg, J. (belief and intention)

Sibajiban (1965) (on Toms on)

Sinisi, V.F. (Leibniz's law and)

[Skinner, B.F.] Hinman, L.M. (can Skinner lie?)

Skinner, R.C. (general)

Skyrms, B. (1970) (quantification and)

Skyrms, B. (1970) (three-valued logic and)

Sloman, A. (Tarski and Frege on)

Smith, H.B. (generalized liar, multiple implication)

Spade, P.V. (medieval)

Thomas, I. (written, and Thomas Oliver)

Toms, E. (1956) (general)

Toms, E. (1958) (reply) 
Tucker, J. (1958-59) (and Gödel)

Ushenko, A.P. (1957) (addendum to note)

Ushenko, A.P. (1937) (new version)

Ushenko, A.P. (1955) (note)

van Fraassen, B.C. (1970) (truth and consequences)

Whitely, C.H. (let him lie!)

- Metaphysics.

See also: Freedom, History, Reflexivity in Literature, Reflexivity in Religion, Vicious Circle. For 'Cartesian circle', see Descartes in the main list.

Anscombe, G.E.M. (naturalism)

[Aristotle] Greene, M. (circular movement, logos)

Ballew, L. (Greek)

Bartlett, S.J. (1970) (phenomenology)

Berger, R. (psychlosis, circularity of experience)

Boas, G. (cycles)

Borges, J.L. (sphere)

Boyle, J.M. (1972) (metaphysical argumentation)

Brendel, O. (sphere)

Brown, M. (in German romanticism)

Callois, P. (time)

Chihara, C.S. (1973) (ontology, vicious circle)

Collingwood, R.G. (self-refutation, positivism)

Corbin, H. (cyclical time, Ismaili gnosis)

Eliade, M. (eternal return)

Emerson, R.W. (circles)

[Empedocles] Long, A.A. (cosmic cycle)

[Empedocles] O'Brien, D. (cosmic cycle)

Fitch, F.B. (1963) (perfection of perfection)

[Gödel] Chihara, C.S. (mechanism)

[Gödel] Coder, D. (mechanism)

[Gödel] Desmonde, W.H. (indeterministic systems)

[Gödel] Hanson, W.H. (mechanism)

Harries, K. (sphere)

Harrison, C. (first cause)

[Hegel] Aboulafia, M. (Hegel's system)

Jacobson, N.P. (Buddhism, change, self-correction)

Jaki, S.L. (oscillating universe)

Katz, B.D. (causal criterion of event identity)

Louisell, D.W. (self-creating man) 
Mintz, S.I. (circle of perfection)

Moleski, M.X. (retortion)

[Nagel] Nissen, L. (teleology)

Neumann, E. (creation, perfection)

[Nietzsche] Altizer, T.J.J. (recurrence)

[Nietzsche] Brush, S.G. (recurrence)

[Nietzsche] Clegg, J.S. (cyclical cosmos)

[Nietzsche] Danto, A. (recurrence)

[Nietzsche] Reeves, S. (recurrence)

[Nietzsche] Kain, P.J. (recurrence)

[Nietzsche] Klossowski, P. (recurrence)

[Nietzsche] Krueger, J.. (recurrence)

[Nietzsche] Löwith, K. (recurrence)

[Nietzsche] Small, R. (circular cosmos)

[Nietzsche] Soll, I. (recurrence)

[Nietzsche] Stambaugh, J. (recurrence)

[Nietzsche] Williams, R. (recurrence)

[Nietzsche] Zuboff, A. (recurrence)

Onians, R.B. (time, fate, telos)

[Plato] Apollini, D. (self-predication)

[Plato] Clegg, J.S. (self-predication)

[Plato] Driscoll, J.S. (self-participation)

[Plato] Haynes, R.P. (self-predication)

[Plato] Lee, E.N. (rotation, mind)

[Plato] Nehamas, A. (self-predication)

[Plato] Pinto, W.L. (self-predication)

[Plato] Savan, D. (self-predication)

[Plato] Vlastos, G. (self-predication)

Portmess, L. (time and paradox)

Poulet, G. (circle)

Prado, C.G. (1978) (reflexive awareness)

Prado, C.G. (1978) (reflexive consciousness)

Royce, J. (self-representative systems)

Shafer, I.H. (infinite circle, chiliastic soul)

Veatch, H.B. and Young, T. (and the paradoxes)

[Wittgenstein] Miller, R.W. (self-reference and solipsism)

Young, A.M. (reflexive universe)

- Omnipotence.

See also: Reflexivity in Law, Reflexivity in Religion.

Bonifacio, A.F. 
Cargile, J. (1967)

Cowan, J.L. (1965)

Cowan, J.L. (1974)

Englebretsen, G.

Farrel, P.M.

Frankfurt, H.G.

Geach, P.T. (1973)

Gellman, J.

Gendin, S.

Grave, S.A.

Helm, P.

Hintikka, J. (1958)

Keene, G.B. (1981)

Keene, G.B. (1980)

Khamara, E.J.

King-Farlow, J.

Londey, D.

Mackie, J.L. (1955)

Mackie, J.L. (1962)

Marshall, G. (1954)

Marshall, G. (1957)

Marshall, G. (1955)

Marshall, G. (1966-67)

Marshall, G. (1971)

Mavrodes, G.I.

[Mavrodes] Hoffman, J.

[Mavrodes] Reichenbach, B.R.

Mayo, B.

McLean, M.R.

Meierding, L.

Miller, B.

Phillips, O.H.

Ramsey, I.T.

Rees, W.J.

Rosenkrantz, G. and Hoffman, J.

Ross, A. (1958)

Ross, A. (1969)

Savage, L.W.

Schlesinger, G. (1965)

Swineburne, R.

Tammelo, I. (1958)

Walton, D. (1975) 
Suber

A Bibliography of Works on Reflexivity

Wolfe, J. (1971)

- Paradox.

See also: Liar, Heterological, Impredication, Omnipotence, Russell's Paradox, Self-Reference, Theory of Types, Vicious Circle.

Alexander, P. (pragmatic)

Anderson, A.R. (1964) (review)

Anderson, C.A. (of the knower)

Anon. (1962) (puzzles, problems)

Ashworth, E.J. (inconsistency and paradox; medieval)

Bar-Hillel, Y. (1966) (natural languages)

Bar-Hillel, Y. (1940-41) (semantic)

Beach, E. (of cognitive relativism)

Beard, R.W. (non-communicator)

Behmann, H. (logical)

Beth, E.W. (logical)

Blauberg, I.V., Sadovsky, V.N., Yudin, E.G. (systems thinking)

Bradley, C.K. (general)

Brown, D.B. (without tiers)

Bunch, B.H. (mathematical)

Buridan, J. (medieval)

Cargile, J. (1979) (form and predication)

Chihara, C.S. (1979) (semantic)

Chihara, C.S. (1976) (truth, meaning)

Chihara, C.S. (1977) (Wittgenstein)

Church, A. (1954) (review)

Church, A. (1955) (review)

Church, A. (1934) (Richard's)

Cohen, L.J. (1950) (review)

Colie, R.L. (in Renaissance)

Conway, P.H. (barber)

Craig, W. (omniscience and Newcomb's paradox)

Curry, B. (Kleene and Rosser)

Dalla Chiara, M.L. (set paradoxes, quantum mechanics)

De Cornulier, B. (self-reference)

DeLaguna, T. (logical)

De-Rijk, L.M. (medieval insolubilia)

Drange, T. (1964) (non-communicator)

Drange, T. (1967) (defended)

Drange, T. (1969) (paradox regained) 
Dumitriu, A. (1974) (contemporary and scholastic)

Dumitriu, A. (1974) (Wittgenstein's solution)

Dunn, M.J. (Drange's)

Fitch, F.B. (1979) (excluded middle and)

Fitch, F.B. (1964) (prediction paradox)

Fitch, F.B. (1963) (avoiding Curry's)

Falletta, N. (general)

Fumerton, R.A. (paradox of analysis)

Gardner, M. (general)

Garner, R.T. (non-paradoxical)

Geach, P.T. (1953) (reflexive)

Geach, P.T. (1955) (insolubilia)

Geach, P.T. (1970) (two of Russell's)

[Gödel] Broyles, J.E. (and argument)

[Gödel] Safir, O. (concrete forms)

Goldstein, L. (legal reasoning)

Goldstein, L., and Goddard, L. (strengthened)

Good, I.J. (Richard's)

Grelling, K. (logical)

Grover, D. (inheritors)

Gupta, A. (1982) (truth and paradox)

Haack, S. (general)

Hart, J.A., and Dees, J.G. (grounding, semantics)

Hintikka, J. (vicious circle principle)

Hudson, J.L. (Frege on Russell's)

Hugget, W.J. (lost)

Hughes, P. and Brecht, G. (vicious circle, infinity)

Jackson, F, (Richard's)

Kalmer, L. (review)

Kapadia, R. (found)

Kaplan, D. and Montague, R, (regained)

Kneale, W.C. (Russell's and others)

Kordig, C.R. (1969) (ethical paradox)

Krippendorf, K. (and information)

Lambert, K. (non-communicator)

Langford, C.H. (1950) (general)

Langford, C.H. (1937) (review)

Langford, C.H. (1937) (2d review)

Langford, C.H. (1941) (review)

Langford, C.H. and Langford, M. (general)

MacIver, A.M. (general)

Mackie, J.L. (1973) (truth, probability, and) 
Mackie, J.L. (1971) (learn from)

Mates, B. (genuine problems)

Miller, M.M. (pragmatic)

Muller, G.H. (review)

Myhill, J. (general)

Nagel, E. (1945) (review)

Nelson, E. (review)

Nigel, H. (metagames)

Northrop, E.P. (mathematical)

O'Connor, D.J. (1948) (pragmatic)

O'Connor, D.J. (1951) (pragmatic)

Odegard, D. (parasitical reference)

Paulos, J.A. (self-reference, humor)

[Plato] Smith, J.L. (false statements)

[Plato] Thomas, W.J. (Skolem paradox)

Portmess, L. (time and)

Priest, G. (1979) (logic of)

Priest, G. (1977) (unified account)

Priest, G. (1983) (and excluded middle)

Priest, G. and Mortensen, C. (truth-teller paradox)

Prior, A.N. (1961) (a family of)

Quine, W.V.O. (1955) (a so-called)

Quine, W.V.O. (1962) (general)

Quine, W.V.O. (1966) (Ways of)

[Quine] Roth, P.A. (and indeterminacy thesis)

Reach, K. (name relation)

Regnell, H. (1968) (new approach)

Rescher, N. (1961) (indirect discourse)

Richards, T.J. (self-referential)

Russell, B. (1908) (theory of types)

Russell, B. (1973) (solution to insolubilia)

Shaw-Kwei, M. (for many-valued systems)

Smullyan, R. (1982) (puzzles)

Smullyan, R. (1980) (puzzles)

Smullyan, R. (1979) (puzzles)

Sorensen, R.A. (prediction paradox)

Stack, G.J. (reflexivity, prediction, and)

Steel, T. (reply)

Stenius, E. (semantic, well-formed rules)

Stern, R.H. (patent law priority)

Stone, J.D. (semantic, natural languages)

Stone, R. (in law) 
Stone-de Montpensier, R.L. (1966) (in law)

Stone-de Montpensier, R.L. (1967) (in law)

Strawson, P.F. (and posits, propositions)

Strom, J.J. (squaring circles of logic)

Suits, B. (games and)

Tarski, A. (1956) (truth in formalized languages)

Tarski, A. (1944) (semantic conception of truth)

Tarski, A. (1969) (truth and proof)

Taubes, J. (general)

Taylor, R.G. (mathematical definability and)

Teensma, E. (general)

Thompson, M.H. (and Peirce's semiotic)

Thomson, J.F. (1962) (general)

Thomson, J.F. (1956) (review)

Toms, E. (1952) (reflexive paradoxes)

Tucker, J. (1969) (review)

Turquette, A.R. (review)

Tymoczko, T. ("no one knows this is true")

Ushenko, A.P. (1941) (problems of logic)

van Fraassen, B.C. (1970) (truth, paradoxical consequences)

Van Heijenoort, J. (general)

Veatch, H.B. and Young, T. (and metaphysics)

Visader, J. (Urboric philosophies)

Wand-Schneider, D. (in logic)

Wang, H. (1955) (semantic, undecidability)

Wedberg, A. (review)

Whitehead, A.N., and Russell, B. (general)

[Wittgenstein] Goldstein, L. (logico-semantical paradoxes)

Woodruff, P.W. (truth and logic)

Wormell, C.P. (general)

Wright, E.L. (a solution)

Yuting, S. (two semantical)

- Petitio Principii.

Includes fallacious circular reasoning. See also:

Self-Justification, Vicious Circle. For 'Cartesian circle', see Descartes in the main list.

Achinstein, P. (1963) (and induction)

Achinstein, P. (1962) (an inductive argument)

[Achinstein] Black, M. (an inductive argument)

Allison, H.E. (Berkeley) 
[Anselm] Davis, S.T. (1976) (ontological argument)

[Anselm] Davis, S.T. (1976) (ontological argument, reply)

[Anselm] Devine, P.E. (ontological argument)

[Anselm] Rowe, W.L. (ontological argument)

Barker, J. (fallacy of)

Biro, J.I. (general)

Burkholder, P.M. (in the strife of systems)

Cornforth, M. (dialectical materialism)

[Hegel] Dahlstrom, D.O. (Hegelian logic)

Hoffman, R. (at any time)

[Hume] Goldstick, D. (induction)

Johnson, O.A. (1967) (general)

Johnson, O.A. (1968) (reply)

Johnson, O.A. (1978) (skepticism)

Keene, G.B. (circularity of logic)

Mackenzie, J.D. (avoiding circular proofs)

Mackenzie, J.D. (begging the question in dialogue)

Mavrodes, G.I. (self-referential incoherence)

Naess, A. (skepticism)

O'Connor, J. (eliminating self-reference)

Palmer, H. (circular arguments)

Perelman, Ch., and Olbrechts-Tyteca, L. (beg the question)

Prior, A.N. (1976) (cogito and self-confirmation)

Rescher, N. (1980) (skepticism)

Robinson, R. (1971) (general)

Sanford, D. (1972) (general)

Sanford, D. (1977) (reply to Barker)

Schmidt, P.F. (self-referential justification)

Spackes, A.W. (general)

Walton, D. (1977) (Mill, DeMorgan, on syllogism)

Walton, D. (1980) (and argument analysis)

Walton, D. (1985) (are all circular arguments vicious?)

Williams, M.E. (general)

Woods, J. and Walton, D. (1981) (arguing in a circle)

Woods, J. and Walton, D. (1979) (circular demonstrations)

Woods, J. and Walton, D. (1982) (Aristotle's five ways)

Woods, J. and Walton, D. (1975) (general)

Woods, J. and Walton, D. (1977) (and relevant, many premissedarguments)

Woods, J. and Walton, D. (1982) (and cumulativeness, dialectical games) 
- Reflexivity in Art.

Includes all arts other than literature. See also: Metaphysics, Reflexivity in Literature, Reflexivity in Religion.

Arnheim, R. (power of center; composition)

Brendel, O. (symbolism of sphere)

Burnaby Art Gallery (mystic circle)

Carrier, D. (pictures within pictures)

Coe, R.T. (native Americans)

Cork, R. (vorticism)

Dars, C. (trompe l'oeil)

[Escher, M.C.] Ernst, B. (Escher's magic mirror)

Garvin, L. (paradox of aesthetic meaning)

Hennessey, W.J. (artists on art)

Hofstadter, D.R. (1979) (Escher, Bach)

[Hume] Kivy, P. (standard of taste)

John, J.A., Wolock, F.W., David, H.A. (cyclic designs)

Lipman, J. and Marshall, R. (art about art)

Shephard, R.N. (judments of relative pitch)

Shir, J. (symbolism and autosymbolism)

Simos, M. (spiral dance)

- Reflexivity in Law.

See also: Omnipotence.

Anon. (1922) (circularity of liens)

Anon. (1926) (circularity of liens)

Anon. (1928) (circularity of liens)

Anon. (1938) (circularity of liens)

Anon. (1953) (circularity of liens)

Anon. (1957) (circularity of liens)

Anon. (1940) (bootstrap doctrine)

Aqvist, L. (1981) (Euathlus)

Benson. (circularity of liens)

Bryant, J. (Euathlus)

Campbell. (circularity of liens)

Collier, C.S. (judicial bootstraps)

[Dworkin] Farago, J. (self-reference, rights thesis)

Epstein, D.G. (circularity of liens)

Finkelstein, M. (judicial self-limitation)

George, L.C. (King Solomon, feedback)

Gilmore, G. (circular priority systems) 
Goossens, W.K. (Euathlus)

Hart, H.L.A. (self-referring laws)

Hicks, J.C. (liar in legal reasoning)

Hintikka, J. (1958) (Tammelo on omnipotence)

Hofstadter, D.R. (1982) (Nomic, game of self-amendment)

Kellogg. (circularity of liens)

Kocourek, A. (circularity of liens)

Larson, A. (self-judging)

Lenzen, W. (Euathlus)

Louisell, D.W. (self-creating man)

Mackie, J.L. (omnipotence)

Marshall, G. (1954) (omnipotence)

Marshall, G. (1955) (omnipotence)

Marshall, G. (1955) (omnipotence)

Marshall, G. (1966-67) (omnipotence)

Marshall, G. (1971) (omnipotence)

Maynez, E.G. (antinomies in)

Mishkin, P.J. (prophecy and realism)

Munro, C.R. (renvoi)

Peck. (circuity of liens)

Phillips, O.H. (self-limitation)

Rees, W.J. (omnipotence)

Rinaldi, F. (circles)

Ross, A. (1958) (self-amendment)

Ross, A. (1969) (self-amendment)

[Ross] Hoerster, N. (self-amendment)

[Ross] Raz, J. (self-amendment)

Sagarin, E. and Kelly, R.J. (self-defeating prophecy)

Sigler, J.A. (cybernetics model)

Stern, R.H. (patent priority paradoxes)

Stone, R. (antinomies in)

Stone-de Montpensier, R.L. (1966) (Gödel, liar, etc.)

Stone-de Montpensier, R.L. (1967) (reflexive case)

Suber, P. (Nomic, game of self-amendment)

Tammelo, I. (1958) (omnipotence)

Tyree. (circularity of liens)

White. (circularity of liens)

- Reflexivity in Literature.

See also: Metaphysics, Reflexivity in Art, Reflexivity in Religion, Self-Reference. 
Abrams, M.H. (romanticism)

Alter, R. (novel as self-conscious genre)

[Arrabal] DeLong-Tonelli, B.J. (in Arrabal)

Baker, D.Z. ('self-reflexive' poetry, Pan, Orpheus)

Brendel, O. (symbolism of sphere)

Brown, M. (circular themes in German romanticism)

Calderwood, J.L. (metadrama in Hamlet)

Colie, R.L. (in Renaissance)

Denhard, C.H. (autobiography of book)

Elliott, L. (paradoxes of fiction)

Emerson, R.W. (circles)

[Emerson] Witemeyer, H.H. (in Emerson)

[Eudoxus] Maula, E., Kasanen, E., Mattila, J. (in Eudoxus)

Fish, S.E. (17th century)

Frank, J. (modern)

Füredy, V.Y.G.M. (plays within plays)

Garzelli, E. (modern)

[Grillparzer] Dunham, T.C. (in Grillparzer)

[Guillen] Frutas, E. (in Frutas)

Harries, K. (sphere)

Hirsch, E.D. (self-confirming interpretations)

[Hoffmann] Daemmrich, H.S. (in Hoffmann)

Hollander, J. (self-exemplifying genres, tropes)

Hoy, D.C. (hermeneutics)

Jay, P. (self-representation)

[Jimenez] Olson, P.R. (in Jimenez)

[Jodelle] Reiss, T.T. (in Jodelle)

Kawin, B.F. (reflexive fiction and the ineffable)

Kellman, S.G. (self-begetting novel)

Klinkowitz, J. (self-apparent word)

Lawson, H. (post-modern predicament)

[Malraux] Sonnenfeld, A. (in Malraux)

McCaffery, L. (in Coover, Barthelme, Gass)

[Milton] Grossman, A. (in Milton)

Murillo, L.A. (in Joyce and Borges)

Myers, C.M. (1966) (circular use of metaphor)

Nicolson, M.H. (general)

[Nietzsche] Grimm, R.H. (in Nietzsche)

[Parmenides] Jameson, G. (in Parmenides)

Poulet, G. (general)

Richter, J.P. (circular wit)

Schleuter, J. (metafictional characters) 
Scholes, R. (self-reflexive fiction)

Shafer, I.H. (chiliastic soul in Hegel, Jung, Hesse)

Spinelli, A. (self-describing text)

[Sterne] Diamond, R.J. (paradox of 'Tristram Shandy')

[Sterne] Swearingen, J.E. (in 'Tristram Shandy')

Swearingen, J.E. (reflexivity and decentered self)

[Thoreau] Tuerk, R.C. (in Thoreau)

[Valle-Inclan] Boudreau, H.L. (in Valle-Inclan)

Waugh, P. (metafiction)

Wilson, R.R. (self-referential review of three books on metafiction)

[Wordsworth] Gill, S. (poetic self-reference)

Yoder, R.A. (circular themes in American romanticism)

- Reflexivity in Natural Science.

See also: Metaphysics, Reflexivity in Social Science.

Ashby, W.R. and Riguet, J. (self-organizing systems)

Bartlett, S.J. (1976) (metalogic of reference)

Bartlett, S.J. (1980) (phenomenology)

Berger, R. (circularity of experience; biological)

Braines, S.N., Napalkov, A.V., and Shreider, I.A. (1959) (selforganizing systems)

Csanyi, V. and G. Kampis (autogenesis)

Dalla Chiara, M.L. (set paradoxes, quantum mechanics)

Derr, P.G. (methodology)

Eigen, M. and Schuster, P. (self-organization)

Farber, E. (chemistry)

Foerster, H. von (circular causation in biological systems)

[Gödel] Yourgrau, W. (Gödel and physical theory)

Hofstadter, D.R. (1979) (genetic code)

Hofstadter, D.R. (1983) (self-replicating structures)

Hull, D.L. (evolutionary taxonomy)

Jaki, S.L. (oscillating universe)

Jantsch, E. (self-organizing universe)

Kordig, C.R. (1970) (self-reference, objectivity, change)

Levi, I. (self-correcting induction)

Louisell, D.W. (biology, self-creating man)

Maturana, H.R. and F.J. Varela (autopoiesis and cognition)

Michie, D. and Longuet-Higgens, C. (game modeling replication)

Poundstone, W. (recursion and limits of scientific knowledge)

Radnitzky, G. (reflexive method)

Rorty, R. (1979) (transcendental arguments, self-reference) 
Sommers, f. (1964) (predictability)

Thomsen, D.E. (self-assembly)

Varela, F.J. (biological autonomy)

[Vitrivius] Plommer, H. (in Vitrivius)

Young, A.M. (reflexive universe)

Zeleny, M. (autopoiesis, biology)

- Reflexivity in Religion.

See also: Metaphysics, Omnipotence, Reflexivity in Art, Reflexivity in Literature.

Altizer, T. (self-embodiment of god)

[Anselm] Davis, S.T. (1976) (ontological argument)

[Anselm] Davis, S.T. (1976) (ontological argument, reply)

[Anselm] Devine, P.E. (ontological argument)

[Anselm] Rowe, W.L. (ontological argument)

[Aquinas] Donceal, J.F. (Aquinas)

Baker, D.Z. ('self-reflexive' poetry, Pan, Orpheus)

Begley, W.E. (Visnu's flaming wheel)

Burnaby Art Gallery (mysticism)

Campbell, J. (myth)

Coe, R.T. (native Americans)

Corbin, H. (cyclical time, Ismaili gnosis)

Craig, W. (omniscience and Newcomb's paradox)

Daye, D.D. (1979) (induction, Jains)

Daye, D.D. (1975) (Buddhist causality)

Dominian, J. (affirmation)

Eliade, M. (myth of eternal return)

Emerson, R.W. (circles)

Evans, D.D. (self-involvement)

Fingarette, H. (self in the Analects)

Fitch, F,B. (1948) (God and immortality)

Fitch, F.B. (1963) (perfection of perfection)

[Gödel] Benacerraf, P. (God, devil, and Gödel)

Goldin, J. (Honi, prayer)

Harries, K. (sphere)

Harrison, C. (first cause)

Jacobson, N.P. (Buddhism, self-correction)

Kautsky, J.H. (myth)

Kellenberger, J. (ineffabilities)

Lawrence, I. (self-definition)

Levine, M. (self-authenticating experiences) 
Mackay, A. (mandala thinking)

Mintz, S.I. (circle of perfection)

Morreall, J. (god as self-explanatory)

Neumann, E. (creation myths)

Nicolson, M.H. (general)

Oakes, R.A. (self-authentication)

Poulet, G. (general)

Royce, J. (self-representative systems, god)

Sell, J.J. (self-predication statements of 'Jesus')

Shovokhova, E.B. (psychics)

Spiros, M. (spiral dance)

Simpson, W. (Buddhist praying wheel)

Visader, J. (Urboric philosophies)

- Reflexivity in Social Science.

See also: Reflexivity in Natural Science, Self-Fulfilling Prophecies.

Ashby, W.R. (1947) (self-organizing systems)

Ball, T. (social deviance theory)

Bartlett, S.J. (1977) (reflexive predictions in)

Bowerman, W.R. (self-referent causal attributions)

Denzin, N.K. (patient-therapist)

Der, P.G. (methodology)

Filmer, P. (sociology)

Foerster, H. von (circular causation in social systems)

Garfinkel, H. (stance of sociologist)

Gewirth, A. (can people change laws of social science?)

Goffman, E. (frame analysis)

Gruenberg, B. (sociology of science)

Heap, J.L. (description in ethnomethodology)

Henshel, R.L. (1976) (social prediction)

Henshel, R.L. (1975) (scientific status)

Henshel, R.L. (1971) (sociology)

Henshel, R.L., and Kennedy, L.W. (1973) (social prediction)

Krishna, D. (nature of society)

Muller, N. (political strategy)

Noelle-Neumann, E. (public opinion feedback spirals)

Rothschild, K.W. (cobweb cycles, forecasting)

Sandywell, B. et al (reflexivity and dialectics)

[Skinner] Hinman, L.M. (can he lie?)

Smale, G.G. (self-fulfilling prophecies) 
Wolf, E. (invasion-succession, self-fulfilling prophecy)

- Russell's Paradox.

See also: Impredication, Paradox, Self-Reference, Theory of Types, Vicious Circle.

Crossley, J.N.

Geach, P.T. (1970)

Hudson, J.L.

Kneale, W.C.

Mates, B. (1981)

Moulder, J.

Odegard, D.

Russell, B. (1908)

Russell, B. (1973)

Swiggert, P.

- Self-Application.

See also: Impredication, Self-Description, Self-Reference.

Bertoldi, E.F. (phenomenology)

Burge, T. (1978) (reasoning)

Davis, W.H. (perspectivism)

Denhard, C.H. (autobiography of book)

Dingler, H. (definitions)

Henshel, R.L. (1976) (future of prediction)

Kosman, L.A. (perception)

Myhill, J. (system defining its own truth)

Richman, R.J. (theories of meaning)

Sibajiban (1962) (doubt)

- Self-Deception.

Includes only works treating self-deception as a reflexive paradox. See also: Paradox, Reflexivity in Social Science.

Bahnsen, G.L.

Champlin, T.S. (1976)

Champlin, T.S. (1977)

Cosentino, D.A.

Daniels, C.B.

Haight, M.R.

Mele, A.R. 
Siegler, F.A.

- Self-Description.

See also: Impredication, Self-Application, Self- Reference.

Bertoldi, E.F. (phenomenology)

Burge, T. (1978) (reasoning)

Elgin, C.Z. (saying what is shown)

Grambs, D. (words about words)

Harris, R. (1968) (and theory of types)

Harris, R. (1967) (semantics of)

Hollander, J. (self-exemplifying genres, tropes)

Lawrence, I. (self-definition)

Nell, E. (1966) (impossible)

Nell, E. (1967) (semantics of)

Orr, W.F. (self-predicative bibliography)

Pei, M. (self-designation)

Spinelli, A. (self-describing text)

- Self-Fulfilling Prophecies.

Includes self-falsifying, self-altering, and self-affecting prophecies. See also: Feedback, Reflexivity in Social Science.

Archibald, P. (general, psychology)

Armstrong, D.M. (self-fulfilling beliefs)

Ball, T. (social deviance theory)

Bartlett, S.J. (1977) (in behavioral science)

Bendiner, R. (election results)

Buck, R.C. (1963) (general)

Buck, R.C. (1963) (rejoinder to Grunbaum)

[Buck] Grunbaum, A. (review)

Chowdry, K., and Newcomb, T.M. (leaders and groups)

Denzin, N.K. (patient-therapist)

Eliot, T.D. (reaction to assumptions)

Fitch, R.B. (1964) (prediction paradox)

Grunberg, E. and Modigliani, F. (general)

Henshel, R.L. (1975) (effects of prestige)

Henshel, R.L. (1976) (future of prediction)

Henshel, R.L. (1978) (self-altering)

Henshel, R.L. (1971) (sociology)

Henshel, R.L., and Kennedy, L.W. (social prediction)

Jones, R.A. (general) 
Kautsky, J.H. (myth)

Kester, S.W. and Letchworth, G.A. (teacher, student)

Krishna, D. (nature of society)

Merton, R.K. (1948) (general)

Merton, R.K. (1968) (general)

Merton, R.K. (1936) (social action)

Mishkin, P.J. (realism and Supreme Court)

Oldenquist, A. (self-prediction)

Romanos, G.D. (general)

Rothschild, K.W. (cobweb cycles, forecasting)

Sagarin, E. and Kelly, R.J. (self-defeating prophecy)

Scriven, M. (human unpredictability)

[Scriven] Lewis, D.K. and Richardson, J.S. (on Scriven)

Simon, $\mathrm{H}$. (election predictions)

Smale, G.G. (in helping relationships)

Sorensen, R.A. (prediction paradox)

Stack, G.J. (and paradox)

Talland, G.A. (leaders and group opinion)

Vetterling, M.K. (general)

Wolf, E. (invasion-succession sequence)

- Self-Justification.

Includes non-fallacious circular reasoning. See also: Paradox, Petitio Principii, Self-Refutation, Vicious Circle.

Achinstein, P. (1963) (induction)

Achinstein, P. (1962) (an inductive argument)

[Achinstein] Black, M. (an inductive argument)

Alston, W.P. (1976) (self-warrant)

Alston, W.P. (1980) (self-presenting)

Armstrong, D.M. (self-fulfilling beliefs)

Briskman, L.B. (bootstrap rationality)

Chisholm, R. (1966) (self-presenting)

Cornforth, M. (dialectical materialism)

Edidin, A. (bootstrapping without boots)

Glymour, C. (bootstraps, probabilities)

[Hegel] Dahlstrom, D.O. (Hegelian logic)

[Hegel] Rockmore, T. (1981) (epistemological circularity)

[Hegel] Rockmore, T. (1986) (epistemological circularity)

Herzberger, H.G. (grounding, semantics)

Hirsch, E.D. (self-confirmability)

Horwich, P. (bootstrap condiditions) 
Johnson, O.A. (skepticism)

Keene, G.B. (1975) (circularity of logic)

Keller, J.A. (circular justification and foundationalism)

Kvanvig, J.L. (self-warrant foundationalism)

Levine, M. (self-authenticating experiences)

Merleau-Ponty, M. (circular dialectic)

Miller, M.M. (self-referring knowledge claims)

Moleski, M.X. (retortion)

Myhill, J. (system defines its own truth)

Naess, A. (skepticism)

Oakes, R.A. (self-authentication)

Odegard, D. (1976) (knowledge and reflexivity)

Pastin, M. (self-warrant)

[Plato] Duff-Forbes, D.R. (regress arguments)

[Plato] Yartz, F.J. (infinite regress)

Price, H.H. (self-verifying beliefs)

Prior, A.N. (1976) (self-confirmation)

Rescher, N. (1980) (skepticism)

Schmidt, P.F. (self-referential justification)

Sextus Empiricus (skepticism)

Sibajiban (doubting doubt)

Simson, R. (epistemic regress)

Walton, D.N. (are all circular arguments vicious?)

Whewell, D. (self-guaranteeing statements)

Williams, J.N. (justification, infinite regress)

Woods, J. and Walton, D. (1981) (arguing in a circle)

Young, R. (sound self-referential argument?)

- Self-Reference.

Note that many writers use "self-reference" as the generic term for reflexivity. All other rubrics may be relevant.

Ashworth, E.J. (1976) (medieval)

Bar-Hillel, Y. (1966) (natural languages)

Bartlett, S.J. (1970) (conceptual pathology)

Bartlett, S.J. (1975) (metalogic of reference)

Bartlett, S.J. (1976) (metalogic of reference)

Bartlett, S.J. (1980) (phenomenology, science)

Bartlett, S.J. (1982) (self-referential consistency)

Bartlett, S.J. (1988) (varieties of)

Bartlett, S.J. and P. Suber (eds.) (general; anthology)

Bateson, G. (play) 
Boyle, J.M. (1972) (self-referential inconsistency)

Boyle, J.M., Grisez, G., Tollefsen, O. (1972) (self-referential argument)

Boyle, J.M., Grisez, G., Tollefsen, O. (1976) (self-referential argument)

Burge, T. (1974) (demonstrative constructions)

Buridan, J. (medieval)

Cargile, J. (1969) (review)

Cargile, J. (1967) (review)

Chisholm, R. (1981) (first person)

Coval, S. (1966) (first person)

Coval, S. (1974) (self-reference, non-selves)

Dalla Chiara, M.L. (set paradoxes, quantum mechanics)

De Cornulier, B. (paradoxical)

DeGeorge, T.S. (reason, truth, context)

Denhard, C.H. (autobiography of book)

Dingler, $\mathrm{H}$. (definitions)

[Dworkin] Farago, J. (rights thesis)

Eckel, M.D. (Bhavaviveka)

Elgin, C.Z. (saying, showing)

Fitch, F.B. (1946) (in philosophy)

Fitch, F.B. (1953) (relations)

Fitch, F.B. (1988) (formalized)

Fox, R. (philosophy and)

Gibbons, T.F. (critical rationalism)

Gödel, K. (incompleteness theorem)

[Gödel] Findlay, J. (Goedelian sentences)

Harel, D. et al. (self-reference referenced)

Hart, H.L.A. (laws)

Hart, W.D. (1979) (general)

Hart, W.D. (1988) (causation and)

Hofstadter, D.R. (1979) (art, science, computing)

Hofstadter, D.R. (1981) (sentences)

Hofstadter, D.R. (1981) (cognition)

Hofstadter, D.R. (1982) (more sentences)

Hofstadter, D.R. (1982) (Nomic, game of self-amendment)

Hofstadter, D.R. (1982) (metaphors explaining Gödel)

Johnstone, A.A. (double life, Gödel)

Johnstone, H.W. (1970) (persons)

Johnstone, H.W. (1970) (persons, 2d article)

Johnstone, H.W. (1988) (ad hominem and self-reference)

Jorgensen, J. (1955) (reflexions) 
Kattsoff, L.O. (reflections)

Keene, G.B. (1983) (self-referent inference)

Kohl, H.R., and Parsons, L. (truth and provability)

Kordig, C.R. (1970) (objectivity, scientific change)

Kordig, C.R. (1982) (self-referential inconsistency)

Krippendorff, K. (self-referential imperative)

Marans, D. (on reflexiveness)

Martin, R.M. (pragmatics of)

Mays, W. (persons)

Miller, M.M. (1977) (knowledge claims)

Miller, M.M. (1968) (thumb-chasing game)

Morton, J. (recursive reference)

Mostowski, A. (1946) (review)

Mott, P. (dates, tenseless verbs)

Myhill, J. (1966) (system defines its own truth)

Nell, E. (1966) (self-description)

Nell, E. (1967) (self-description)

Niemi, G.W. (modality and)

[Nietzsche] Grimm, R.H. (in Nietzsche)

Nozick, R. (reflexivity generally)

O'Carroll, M.J. (1967) (classical logic)

O'Carroll, M.J. (1967) (a logic consistent for all such)

O'Connor, J. (1968) (eliminating it)

Odegard, D. (parasitical reference)

Parker, D.H. (reflexive relations)

Paulos, J.A. (and paradox, humor)

[Plato] Spitzer, A. (in Gorgias)

Popper, K. (1954) (and meaning, ordinary language)

Prior, A.N. (1959) (review)

Prior, A.N. (1959) (2d review)

Prior, A.N. (1962) (in Buridan)

Rankin, K.W. (referential identifiers)

Rechtin, L. and Todd, W. (propositional attitudes and)

Read, S. (and validity)

Regness, H. (on reflexivity)

Rescher, N. (1961) (statements)

Richards, T.J. (and paradox)

Richman, R.J. (of meaning theory)

Rorty, A.O. (1979) (reflexive attitudes)

Rorty, A.O. (1980) (and theory of error, method)

Rorty, R. (1961) (reductionism)

Rorty, R. (1979) (transcendental arguments) 
Sartre, J.-P. (dialectic)

Schlesinger, G. (1969) (eliminating it)

Schlesinger, G. (1967) (eliminating it)

Schmidt, P.F. (self-referential justification)

Schwartz, E.M. (paradox or bluff?)

Shiner, R.A. (and third man argument)

Shir, J. (symbolism and autosymbolism)

Shoemaker, S. (and self-awareness)

Shoenfield, J.R. (review)

Skyrms, B. (1970) (quantification and)

Skyrms, B. (1976) (semantical reference and)

Skyrms, B. (1978) (modality)

Smorynski, C. (1979) (calculations)

Smorynski, C. (1981) (Guaspari sentences)

Smorynski, C. (1981) (in arithmetic)

Smorynski, C. (1984) (and modal logic)

Smullyan, R. (1981) (diagonalization and)

Smullyan, R. (fixed points and)

Smullyan, R. (1957) (languages in which it is possible)

Smullyan, R. (1982) (puzzles)

Smullyan, R. (1980) (puzzles)

Smullyan, R. (1978) (puzzles)

Smullyan, R. (1988) (quotation and)

Spade, P.V. (1975) (medieval insolubilia)

Spade, P.V. (1974) (Ockham on)

Strom, J.J. (squaring the circles of logic)

Suber, P. (1982) (Nomic, game of self-amendment)

Suber, P. (1988) (a bibliography of)

Swiggert, P. (in formal languages)

Thomson, J.F. (1956) (review)

Trigg, G.L. (self-violating rules)

van Fraassen, B.C. (1970) (inference and)

van Fraassen, B.C. (1968) (presupposition, implication and)

Varela, F. (1975) (a calculus for)

Wagner, R. (symbols that stand for themselves)

Webb, J.C. (mechanization of)

[Wittgenstein] Miller, R.W. (and solipsism)

[Wittgenstein] Worthington, B.A. (and self-consciousness)

Whewell, D.A. (and meaning in a natural language)

Wood, L. (self-referentially inconsistent arguments)

Wormell, C.P. (paradoxes of)

Young, R. (sound self-referential argument?) 
- Self-Refutation.

See also: Petitio Principii, Self-Justification, Vicious Circle.

Anscombe, G.E.M. (naturalism)

Baldwin, H.W. (logic of)

Ball, T. (self-subversion)

Bennet, J. (1965) (review)

Boyle, J.M. (1970) (self-referential consistency)

Boyle, J.M. (1988) (determinism)

Burnyeat, M.F. (Jan. 1976) (Protagoras)

Burnyeat, M.F. (April 1976) (Protagoras)

Churchland, P.S. (determinism)

Collingwood, R.G. (positivistic metaphysics)

Davis, W.H. (perspectivism)

Finnis, J.M. (skepticism)

Johnson, O.A. (skepticism)

Johnstone, H.W. (1964) (and validity)

Knaster, S. (determinism)

Mackie, J.L. (1964) (formal analysis of)

Marshall, J., Peters, M., and Shepheard, M. (against Young)

Meiland, J.W. (1980) (cognitive relativism)

Meiland, J.W. (1979) (Protagorean relativism)

Moleski, M.X. (retortion)

Naess, A. (skepticism)

Popper, K. (1983) (determinism)

Sextus Empiricus (skepticism)

[Skinner] Hinman, L.M. (can he lie?)

Stack, M. (self-refuting arguments)

Trigg, G.L. (self-violating rules)

Whewell, D. (self-refuting statements)

Wood, L. (self-referentially inconsistent arguments)

Woods, J. and Walton, D. (1981) (arguing in a circle)

- Theory of Types.

See also: Impredication, Paradox, Russell's Paradox, Self-Reference, Vicious Circle.

Bausch, A. (review)

Brown, D.B. (paradox without tiers)

Fitch, F.B. (1946) (remarks on)

Harris, R. (1968) (self-description) 
Harrison, C. (totalities)

Keller, J.A. (circular justification and levels gambit)

Lawrence, $N$. (heterology and hierarchy)

O'Carroll, M.J. (1967) (non-levelled logic for self-reference)

Pap, A. (linguistic hierarchy, vicious circle)

Quiney, H.R. (non-hierarchical logic)

Resnick, M.D. (Goddard and)

Russell, B. (1908) (general)

Skyrms, B. (1978) (modality)

Ushenko, A.P. (1934) (modification of)

Whitehead, A.N., and Russell, B. (general)

- Vicious Circle.

See also: Paradox, Russell's Paradox, Self-Justification, Self-Reference, Self-Refutation, Theory of Types.

Chihara, C.S. (1973) (ontology)

[Hegel] Dahlstrom D.O. (Hegelian logic)

Hintikka, J. (1957) (and paradoxes)

Hollister, W.W. (conduct)

Hughes, P., and Brecht, G. (and infinity, paradoxes)

Hugly, P. (semantical account of)

Jensen, R. (review)

Menninger, $\mathrm{K}$. (love and hate)

Pap, A. (linguistic hierarchy and)

Priest, G. (1976)

Rutter, M., and Madge, N. (cycles of disadvantage)

Sherwood, R. (race, vicious and benign spirals)

Stack, M. (self-refuting arguments)

Steiner, M. (review)

Whitehead, A.N., and Russell, B. (general) 